\title{
IWTU TI-102 - Part 2 Sample Analyses
}

\author{
Nick Soelberg
}

\author{
March 2016
}

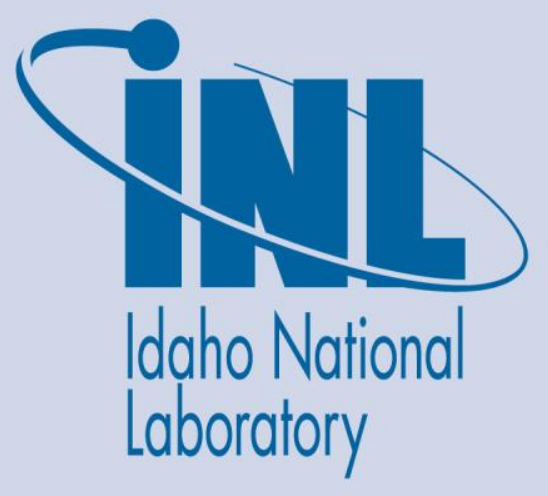

The INL is a U.S. Department of Energy National Laboratory operated by Battelle Energy Alliance 


\section{DISCLAIMER}

This information was prepared as an account of work sponsored by an agency of the U.S. Government. Neither the U.S. Government nor any agency thereof, nor any of their employees, makes any warranty, expressed or implied, or assumes any legal liability or responsibility for the accuracy, completeness, or usefulness, of any information, apparatus, product, or process disclosed, or represents that its use would not infringe privately owned rights. References herein to any specific commercial product, process, or service by trade name, trade mark, manufacturer, or otherwise, does not necessarily constitute or imply its endorsement, recommendation, or favoring by the U.S. Government or any agency thereof. The views and opinions of authors expressed herein do not necessarily state or reflect those of the U.S. Government or any agency thereof. 


\title{
IWTU TI-102 - Part 2 Sample Analyses
}

\author{
Nick Soelberg
}

March 2016

Idaho National Laboratory

Idaho Falls, Idaho 83415

http://www.inl.gov 
This page is intentionally blank 


\section{SUMMARY}

Samples from the Integrated Waste Treatment Unit (IWTU) were collected for analysis after Test Instruction (TI)-102 - Part 2 shutdown. The scope of analyses performed by Battelle Energy Alliance (BEA) included:

- $\quad$ Scanning electron micrography (SEM) and energy dispersive spectroscopy (EDS) analysis for particle morphology, particle size, and elemental composition estimates

- $\quad$ Loss on ignition (LOI) for determining the fraction that is coke and not bauxite

- $\quad$ Proximate and ultimate analysis

- $\quad$ Particle-size analysis using sieve trays

- $\quad$ Bulk and particle density

- Elemental analysis

- Solubility

- $\quad$ X-ray diffraction for mineralogy analysis

- $\quad$ Thermal gravimetric analysis (TGA)

This report provides the results of those analyses. 
This page is intentionally blank 


\section{ACKNOWLEDGEMENTS}

The author thanks the analysts who performed the analyses. Paula Hahn performed the scanning electron microscopy (SEM) energy dispersive spectroscopy (EDS) analyses. Sabrina Morgan performed the loss on ignition (LOI) analyses. Rachel Emerson performed the thermogravimetric (TGA) analyses. Sergio Hernandez performed the ultimate and proximate analyses. Arnold Erickson performed the X-ray diffraction (XRD) analyses. R. Duane Ball performed all the other analyses. Kristyn Roscioli coordinated the sample analyses. 
This page is intentionally blank 


\section{CONTENTS}

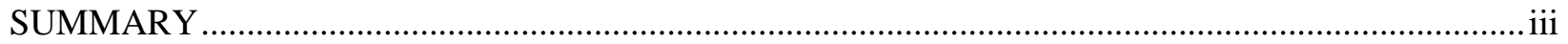

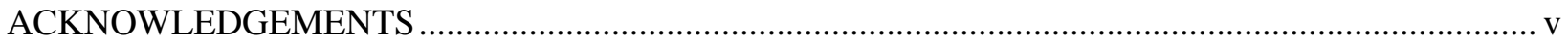

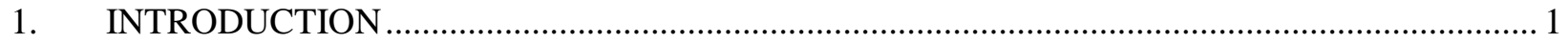

2. DMR BED PRODUCT SEM/EDS ANALYSIS RESULTS.................................................. 2

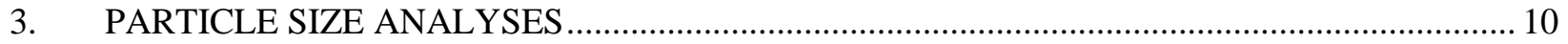

4. DMR WALL AND AUGER SCALE SEM/EDS ANALYSES …….......................................... 12

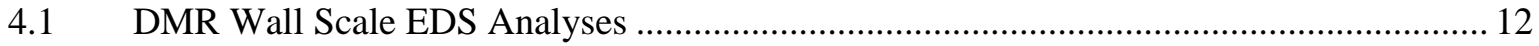

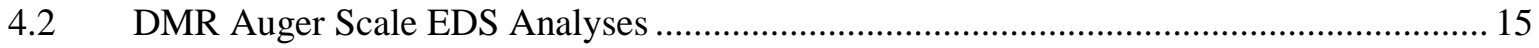

4.3 Comparison of DMR bed media, wall scale, and auger scale EDS analyses ..................... 16

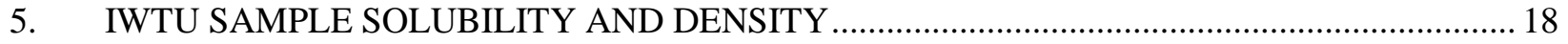

6. ELEMENTAL COMPOSITIONS FROM WET CHEMISTRY ANALYSIS …........................... 20

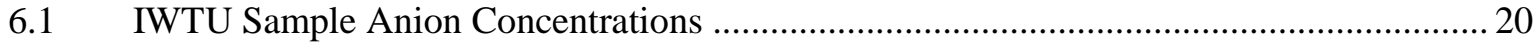

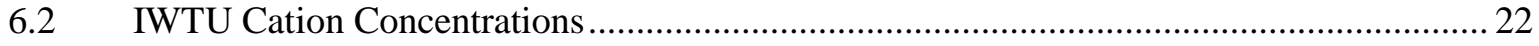

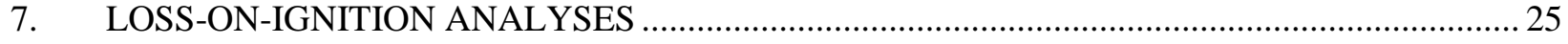

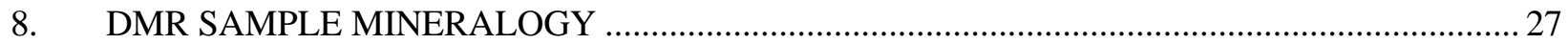

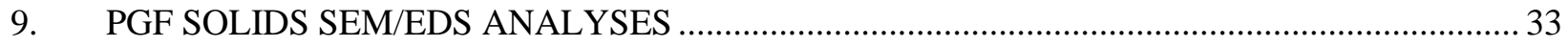

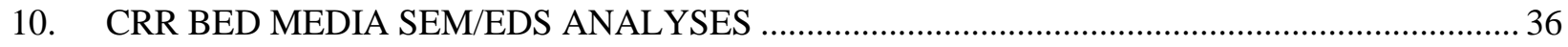

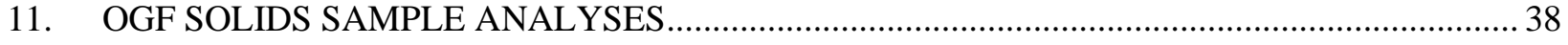

12. OFF-GAS SYSTEM LOW POINT CONDENSATE ANALYSES …........................................ 43

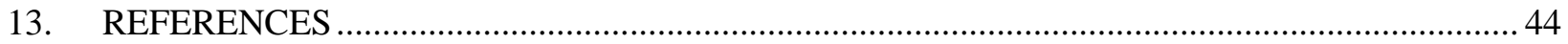

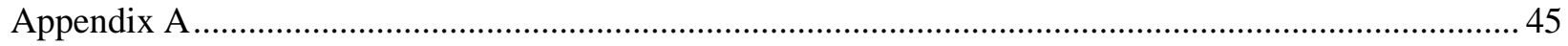

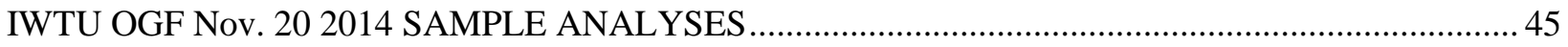

\section{TABLES}

Table 2-1. Elemental analysis from SEM/EDS for the Jan. 2, 2015 DMR bed product sample.

Table 2-2. Elemental analysis from SEM/EDS for the DMR bed removed after shutdown (drums 3 and 5, January 13, 2015).

Table 2-3. Elemental analysis from SEM/EDS for the DMR bed removed after shutdown (Drum 6 January 13, 2015).

Table 2-4. Elemental analysis from SEM/EDS for the DMR bed removed after shutdown (sampled on January 22, 2015).

Table 3-1. Particle size analysis results for DMR, PGF, CRR, and OGF samples. 10

Table 4-1. Elemental analysis from SEM/EDS for the Jan. 13, 2015 DMR wall scale sample (ground to obtain better averages). 
Table 4-2. Elemental analysis from SEM/EDS for the Jan. 13, 2015 DMR wall scale sample (black outside adhered to metal wall).

Table 4-3. Elemental analysis from SEM/EDS for the Jan. 13, 2015 DMR wall scale sample (white inner portion)

Table 4-4. Elemental analysis from SEM/EDS for the Jan. 13, 2015 DMR wall scale sample (black inside facing bed).

Table 4-5. EDS compositions of the A/G scale (January 19, 2015 sample)......................................... 15

Table 4-6. Average EDS compositions of 4 DMR samples, wall scale, and A/G scale........................... 17

Table 5-1. DMR bed, wall scale, and A/G scale sample water solubility test results.............................. 18

Table 5-2. DMR bed sample bulk and particle density...................................................................... 19

Table 6-1. Anion concentrations in the DMR samples from sequential cold and hot water leaches.........21

Table 6-2. Anion concentrations in the DMR samples from a single hot water leach............................22

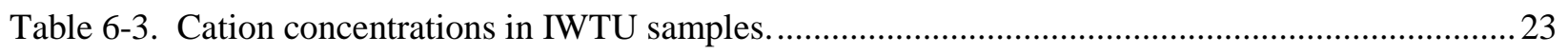

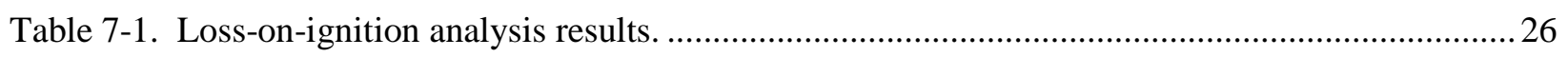

Table 9-1. Elemental analysis from SEM/EDS for the PGF solids Feb. 2, 2015 . ................................. 35

Table 10-1. Elemental analysis from SEM/EDS for the CRR bed media Jan. 18, 2015, Sample 11........ 37

Table 11-1. OGF Nov. 20, 2014 sample proximate and ultimate analysis............................................. 38

Table 11-2. Elemental analysis from SEM/EDS for the OGF solids drums 1-5 19 Jan. 19, 2015 (Sample

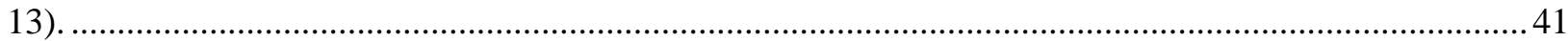

Table 11-3. Elemental analysis from SEM/EDS for the OGF solids drums 21-24 19 Jan. 19, 2015 (Sample 17)

Table 11-4. Elemental analysis from SEM/EDS for OGF solids collected on Jan. 22, 2015 (Sample 19).

Table 11-5. Average of elemental analyses from SEM/EDS for the post-TI-102 OGF solids samples.... 42

Table 12-1. Anion concentrations in low-point drain condensate samples.

\section{FIGURES}

Figure 2-1. SEM photograph of DMR bed product sampled on January 2, 2015, at 100x magnification. . 2 Figure 2-2. SEM photograph of DMR bed product sampled on January 2, 2015, at 2,000x magnification.

Figure 2-3. SEM photograph of DMR bed removed after shutdown (collected from drums 3 and 5, January 13, 2015), at 50x magnification.

Figure 2-4. SEM photograph of DMR bed removed after shutdown (Drum 6, January 13, 2015), at 200x magnification.

Figure 2-5. SEM photograph of DMR bed removed after shutdown (sampled on January 22, 2015), at 50x magnification. 
Figure 2-6. SEM photograph of DMR bed removed after shutdown (sampled on January 22, 2015), at 400x magnification.

Figure 2-7. SEM photograph of DMR bed removed after shutdown (sampled on January 22, 2015), at 2,000x magnification.

Figure 3-1. Particle-size distribution of CRR bed samples removed after Test Period 7 of TI-102 - Part 2, testing.

Figure 4-1. SEM photograph of a fractured inner surface of the DMR wall scale magnified 100x.......... 14

Figure 4-2. Trends of average elemental compositions from EDS for the DMR wall scale..................... 15

Figure 4-3. Comparisons of the EDS compositions for the white and black regions of the A/G scale (January 19, 2015 sample).

Figure 4-4. Comparison of average elemental compositions from EDS for the DMR bed product, the wall scale, and the A/G scale.

Figure 7-1. Individual and averaged LOI results.

Figure 8-1. XRD scan of the January 2, 2015 DMR bed product sample. S-Q in the pattern list indicates semi-quantitative analysis of the crystalline species.

Figure 8-2. XRD scan of the DMR bed sample from drums 3 and 5 collected January 13, 2015...........29

Figure 8-3. XRD scan of the DMR bed sample from drum 6 collected January 13, 2015.....................30

Figure 8-4. XRD scan of the DMR wall scale sample collected January 13, 2015.............................31

Figure 8-5. XRD scan of the DMR A/G scale sample collected January 19, 2015 ............................... 32

Figure 9-1. SEM photograph of PGF solids removed after shutdown (sampled on February 2, 2015), at 50x magnification.

Figure 9-2. SEM photograph of PGF solids removed after shutdown (sampled on February 2, 2015), at 500x magnification, showing particles $>50$ micron.

Figure 9-3. SEM photograph of PGF solids removed after shutdown (sampled on February 2, 2015), at 500x magnification, showing majority of particles $<50$ micron. ........................................................ 34

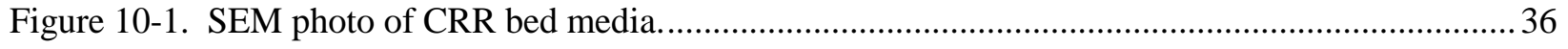

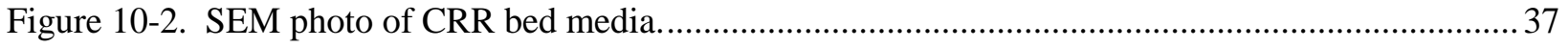

Figure 11-1. SEM photograph of OGF solids from Drums 1 through 5 at 50x magnification.................. 39

Figure 11-2. SEM photograph of OGF solids from Drums 1 through 5 at 400x magnification................ 39

Figure 11-3. SEM photograph of OGF filter solids from Drums 21 through 24 at 50x magnification..... 40

Figure 11-4. Range of elemental concentrations from SEM/EDS analysis for the post-TI-102 OGF solids samples. 
This page is intentionally blank 


\section{ACRONYMS}

$\begin{array}{ll}\text { A/G } & \text { Auger/grinder } \\ \text { BEA } & \text { Battelle Energy Alliance } \\ \text { CRR } & \text { Carbon Reduction Reformer } \\ \text { DMR } & \text { Denitration and Mineralization Reformer } \\ \text { EDS } & \text { energy dispersive spectroscopy } \\ \text { HMPD } & \text { harmonic mean particle diameter } \\ \text { IC } & \text { ion chromatography } \\ \text { IWTU } & \text { Integrated Waste Treatment Unit } \\ \text { LOI } & \text { loss on ignition } \\ \text { MMPD } & \text { mass mean particle diameter } \\ \text { PGF } & \text { Process Gas Filter } \\ \text { PRC } & \text { Product Receiver Cooler } \\ \text { SEM } & \text { scanning electron micrography } \\ \text { TGA } & \text { thermal gravimetric analysis } \\ \text { TI } & \text { Test Instruction } \\ \text { XRD } & \text { x-ray diffraction }\end{array}$


This page is intentionally blank 


\section{IWTU TI-102 - Part 2 Sample Analyses \\ 1. INTRODUCTION}

Samples of Denitration and Mineralization Reformer (DMR) product, DMR wall scale, DMR auger scale, Process Gas Filter (PGF) solids, Carbon Reduction Reformer (CRR) bed media, Off-gas Filter (OGF) solids, and off-gas system condensates were collected for sample analysis after the Test Instruction (TI)-102 - Part 2 shutdown. The scope of analyses performed by Battelle Energy Alliance (BEA) included:

- $\quad$ Scanning electron micrography (SEM) and energy dispersive spectroscopy (EDS) analysis for particle morphology, particle size, and elemental composition estimates

- $\quad$ Loss on ignition (LOI) for determining the fraction that is coke and not bauxite

- $\quad$ Proximate and ultimate analysis

- $\quad$ Particle-size analysis using sieve trays

- $\quad$ Bulk and particle density

- Elemental analysis

- Solubility

- $\quad$ X-ray diffraction for mineralogy analysis

- $\quad$ Thermal gravimetric analysis (TGA).

This report provides the results of those analyses. 


\section{DMR BED PRODUCT SEM/EDS ANALYSIS RESULTS}

Scanning electron microscopy (SEM)/energy dispersive spectroscopy (EDS) was completed on some of the product that was collected from the DMR. Figures 2-1 and 2-2 show the bed media sampled on January 2, 1015. This bed media was sampled after it passed through the DMR Auger/grinder (A/G) and solids handling system to a Product Receiver Cooler (PRC) that was dedicated at the time for processing DMR product, and so should have less if any contamination from OGF or PGF solids. The particles are generally spherical and appear to be the expected type of solids based on pilot-plant testing except for the size, which is smaller than expected. A few larger particles $>100$ micron in diameter were present, but nearly all particles were under 100 microns in diameter.

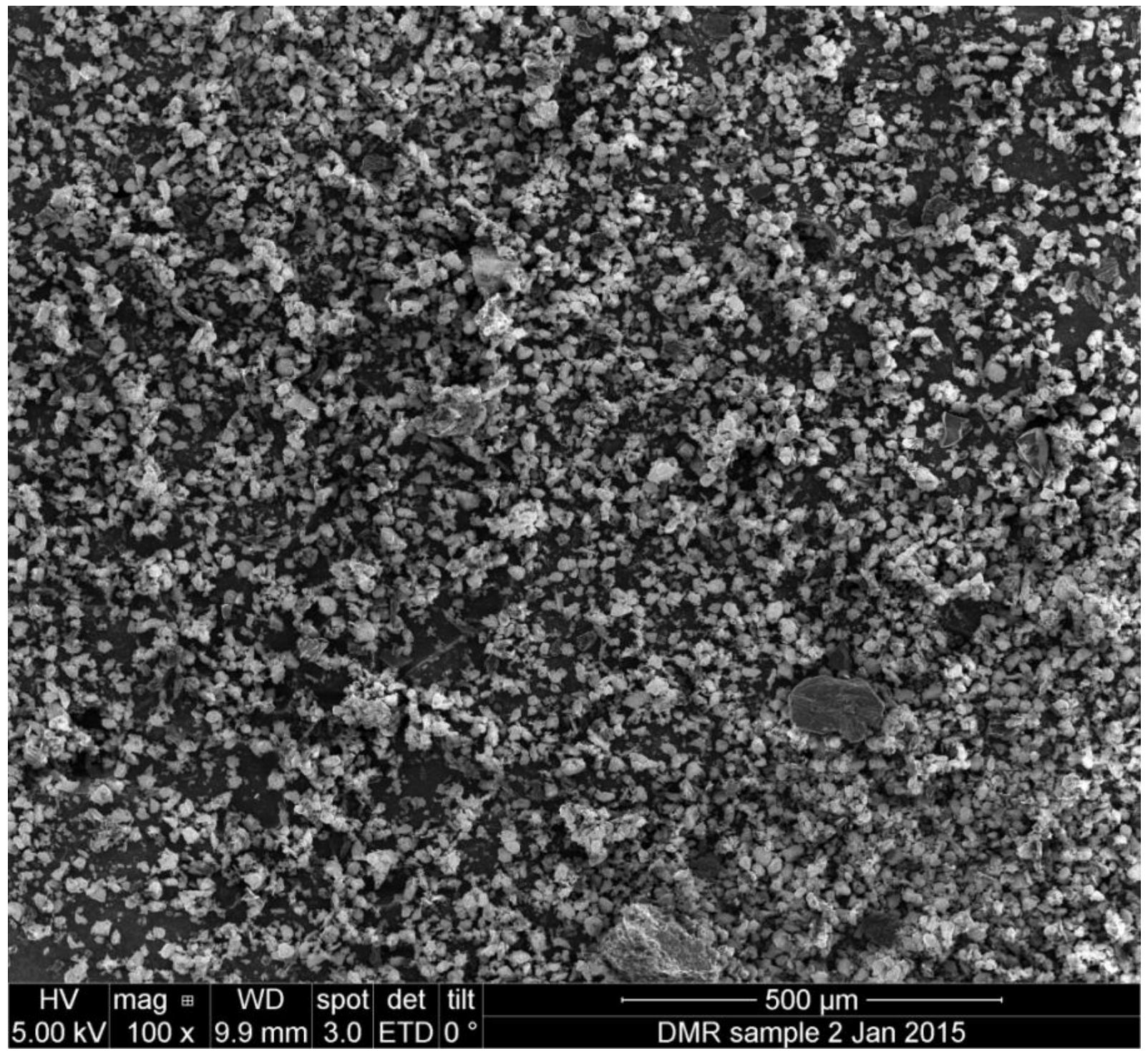

Figure 2-1. SEM photograph of DMR bed product sampled on January 2, 2015, at 100x magnification. 


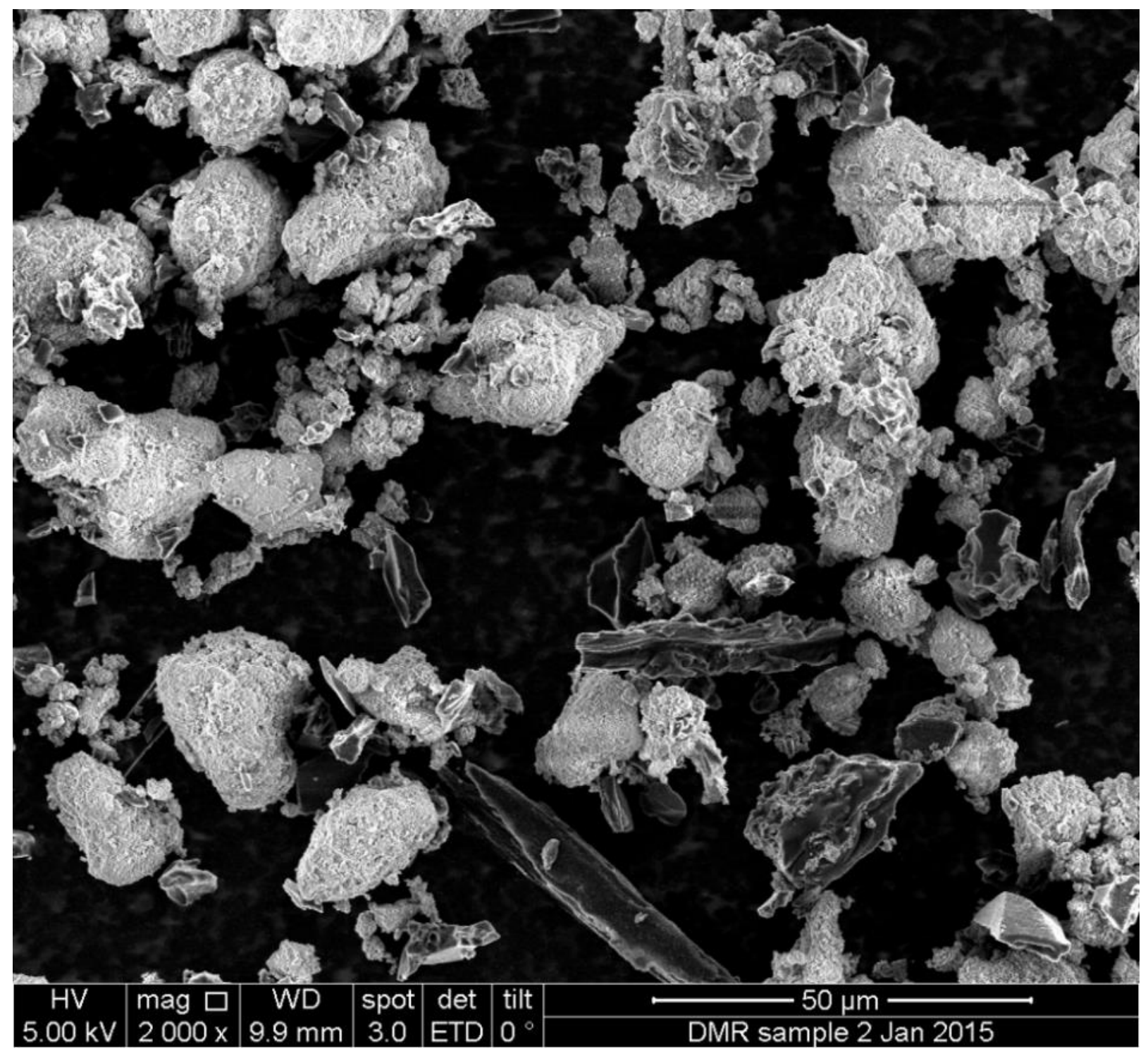

Figure 2-2. SEM photograph of DMR bed product sampled on January 2, 2015, at 2,000x magnification.

The SEM/EDS analyses (Table 2-1) show that the rounded particles that appear white in the photos are primarily sodium and potassium carbonate, aluminate, and aluminosilicate product, and other particles are primarily coal particles. The black, angular-shaped particles are coal particles. The samples are coated with a thin layer of carbon prior to SEM/EDS analysis to provide an electrical conductive path in the SEM, and so the total $\mathrm{C}$ is expected to be biased slightly high (and the non-C elements are biased slightly low). If the particle composition is homogeneous from the surface to the core, then these analyses should be considered representative. The EDS analysis is not calibrated for these sample matrices. The elemental identification and quantification are based on a library of data. It might be reasonable to assume that the experimental error is about $\pm 10 \%$ for values greater than about $10 \mathrm{wt} \%$, $\pm 30 \%$ for values between 1 to $10 \mathrm{wt} \%$, and about $\pm 70 \%$ for values less than $1 \mathrm{wt} \%$. 
Table 2-1. Elemental analysis from SEM/EDS for the Jan. 2, 2015 DMR bed product sample.

\begin{tabular}{|c|c|c|c|c|c|c|c|}
\hline \multirow[b]{2}{*}{ Element } & \multicolumn{7}{|c|}{ Composition, wt\% } \\
\hline & $\begin{array}{c}\text { img-1- } \\
1 . s p c \\
\text { (coal } \\
\text { particle) }\end{array}$ & $\begin{array}{c}\text { img-2- } \\
\text { 1.spc (coal } \\
\text { particle) }\end{array}$ & $\begin{array}{l}\text { img-3- } \\
1 . \mathrm{spc}\end{array}$ & $\begin{array}{l}\text { img-5- } \\
1 . \mathrm{spc}\end{array}$ & $\begin{array}{l}\text { img-6- } \\
1 . \mathrm{spc}\end{array}$ & $\begin{array}{c}\text { img-7- } \\
1 . \operatorname{spc}(\mathrm{FS})\end{array}$ & $\begin{array}{c}\text { Sample } \\
\text { averages } \\
\text { excluding } \\
\text { coal }\end{array}$ \\
\hline C & 75.57 & 84.13 & 26.75 & 32.37 & 59.77 & 48.95 & 41.96 \\
\hline 0 & 11.05 & 8.58 & 33.26 & 30.9 & 20.63 & 26.71 & 27.88 \\
\hline $\mathrm{Na}$ & 2.58 & 1.36 & 21.1 & 18.29 & 2.7 & 11.7 & 13.45 \\
\hline $\mathrm{Al}$ & 0.88 & 0.84 & 14.29 & 13.3 & 7.05 & 8.83 & 10.87 \\
\hline $\mathrm{Si}$ & 0.68 & 2.89 & 1.36 & 1.73 & 8.44 & 1.3 & 3.21 \\
\hline $\mathrm{S}$ & 1.82 & 0.13 & 0.82 & 0.63 & 0.33 & 0.78 & 0.64 \\
\hline $\mathrm{Cl}$ & 0 & 0 & 0 & 0 & 0 & 0 & 0.00 \\
\hline K & 7.42 & 2.07 & 2.42 & 2.79 & 1.08 & 1.73 & 2.01 \\
\hline $\mathrm{Fe}$ & 0 & 0 & 0 & 0 & 0 & 0 & 0.00 \\
\hline $\mathrm{Zn}$ & 0 & 0 & 0 & 0 & 0 & 0 & 0.00 \\
\hline Total & 100.00 & 100.00 & 100.00 & 100.01 & 100.00 & 100.00 & 100.00 \\
\hline \multicolumn{8}{|l|}{ Notes: } \\
\hline \multicolumn{8}{|c|}{$\begin{array}{l}\text { 1. The samples are coated with carbon to enable electrical charging as needed for } \\
\text { SEM/EDS analysis. The } C \text { content of all samples is biased somewhat high due to the }\end{array}$} \\
\hline \multicolumn{4}{|c|}{ 2. The analyses are normalized to $100 \%$. } & & & & \\
\hline \multicolumn{8}{|c|}{$\begin{array}{l}\text { 3. FS = Full scan or average, which is an average composition for multiple particles } \\
\text { within a specifed area in the SEM field of view. }\end{array}$} \\
\hline
\end{tabular}

[dmr sample psd, eds analysis 15may1515.xIsx]EDS dmr bed samples 
A final DMR bed sample from drums 3 and 5 was collected on January 13, 2015 and is shown in Figure 2-3. These bed product particles appear more uniformly round than those in the January 2 sample. The elemental composition of this sample from SEM/EDS is shown in Table 2-2.

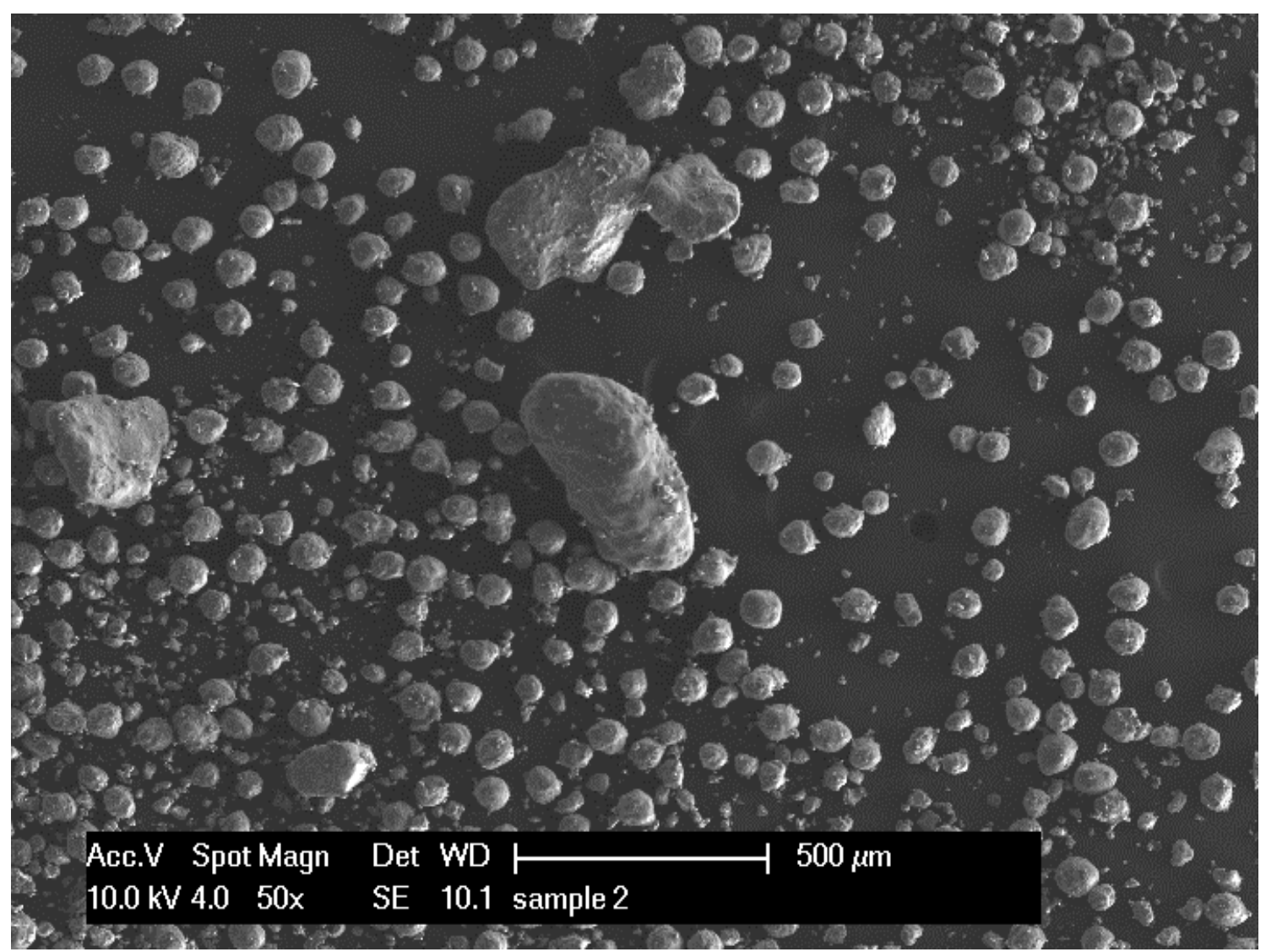

Figure 2-3. SEM photograph of DMR bed removed after shutdown (collected from drums 3 and 5, January 13,2015$)$, at 50x magnification.

Table 2-2. Elemental analysis from SEM/EDS for the DMR bed removed after shutdown (drums 3 and 5, January 13, 2015).

\begin{tabular}{|c|c|c|c|c|c|c|}
\hline \multirow[b]{2}{*}{ Element } & \multicolumn{6}{|c|}{ Composition, wt\% } \\
\hline & $\begin{array}{c}\text { Area scan } \\
1 \text { (coal } \\
\text { particle) }\end{array}$ & $\begin{array}{c}\text { Area scan } \\
2 \\
\end{array}$ & $\begin{array}{c}\text { Area scan } \\
3 \\
\end{array}$ & $\begin{array}{c}\text { Area scan } \\
4 \\
\end{array}$ & $\begin{array}{r}\text { img-6- } \\
1 . \mathrm{spc} \\
\end{array}$ & $\begin{array}{c}\text { Sample } \\
\text { averages } \\
\text { excluding } \\
\text { coal }\end{array}$ \\
\hline C & 91.14 & 20.87 & 22.68 & 41 & 59.77 & 36.08 \\
\hline $\mathrm{O}$ & 5.96 & 35.42 & 35.5 & 32.5 & 20.63 & 31.01 \\
\hline $\mathrm{Na}$ & 0.8 & 24.63 & 24.38 & 13.8 & 2.7 & 16.38 \\
\hline $\mathrm{Al}$ & 0.36 & 14.27 & 11.25 & 6.38 & 7.05 & 9.74 \\
\hline Si & 0.67 & 0.69 & 0.91 & 2.02 & 8.44 & 3.02 \\
\hline S & 0.31 & 1.02 & 1.27 & 0.49 & 0.33 & 0.78 \\
\hline $\mathrm{Cl}$ & 0 & 0 & 0 & 0 & 0 & 0.00 \\
\hline K & 0.77 & 3.1 & 4 & 3.8 & 1.08 & 3.00 \\
\hline $\mathrm{Fe}$ & 0 & 0 & 0 & 0 & 0 & 0.00 \\
\hline $\mathrm{Zn}$ & 0 & 0 & 0 & 0 & 0 & 0.00 \\
\hline Total & 100.01 & 100.00 & 99.99 & 99.99 & 100.00 & 100.00 \\
\hline
\end{tabular}


The DMR bed product from Drum 6 collected on January 13, 2015 is shown in Figure 2-4. This figure shows how one product particle has been broken to reveal an inner core. The EDS elemental composition of the scans indicated in this figure is shown in Table 2-3. The inner core of the broken particle has same general composition as the other product particles (not a core of bauxite, suggesting that this particle did not grow by coating on a bauxite particle, but by onion-ring growth).

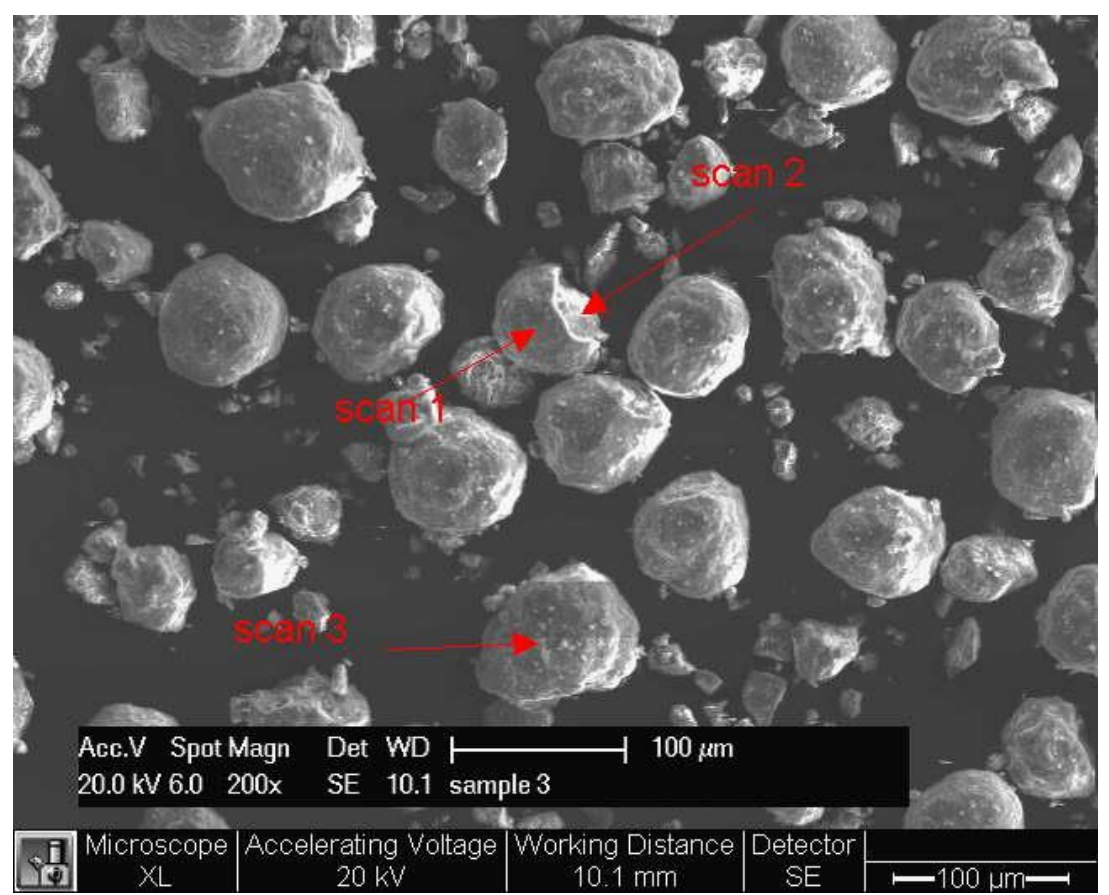

Figure 2-4. SEM photograph of DMR bed removed after shutdown (Drum 6, January 13, 2015), at 200x magnification.

Table 2-3. Elemental analysis from SEM/EDS for the DMR bed removed after shutdown (Drum 6 January 13, 2015).

\begin{tabular}{|c|r|r|r|r|}
\hline & \multicolumn{4}{|c|}{ Composition, wt\% } \\
\cline { 2 - 5 } & & & & \\
& & & & \\
& Point & \multicolumn{1}{|c|}{ Point } & \multicolumn{1}{c|}{ Point } & Sample \\
Element & scan 1 & scan 2 & scan 3 & averages \\
\hline $\mathrm{C}$ & 13.92 & 26.9 & 13.67 & $\mathbf{1 8 . 1 6}$ \\
\hline $\mathrm{O}$ & 38.47 & 39.42 & 38.08 & $\mathbf{3 8 . 6 6}$ \\
\hline $\mathrm{Na}$ & 28.7 & 18.2 & 26.59 & $\mathbf{2 4 . 5 0}$ \\
\hline $\mathrm{Al}$ & 13.44 & 12.24 & 14.99 & $\mathbf{1 3 . 5 6}$ \\
\hline $\mathrm{Si}$ & 0.86 & 0.52 & 1.22 & $\mathbf{0 . 8 7}$ \\
\hline $\mathrm{S}$ & 1.3 & 0.54 & 1.25 & $\mathbf{1 . 0 3}$ \\
\hline $\mathrm{Cl}$ & 0 & 0 & 0 & $\mathbf{0 . 0 0}$ \\
\hline $\mathrm{K}$ & 3.16 & 1.8 & 3.59 & $\mathbf{2 . 8 5}$ \\
\hline $\mathrm{Fe}$ & 0.16 & 0.38 & 0.61 & $\mathbf{0 . 3 8}$ \\
\hline $\mathrm{Zn}$ & 0 & 0 & 0 & $\mathbf{0 . 0 0}$ \\
\hline Total & 99.85 & 100.00 & 100.00 & $\mathbf{9 9 . 6 2}$ \\
\hline
\end{tabular}


The DMR bed media sampled on January 22, 2015 is shown in Figures 2-5 through 2-7. These figures show, with increasing magnification, whole product particles and one broken product particle. The EDS elemental composition of the scans indicated in these figures are shown in Table 2-4. The inside of the broken particle is the same general composition as the whole particles, and does not have a bauxite core, but is a result of new product growing on a particle (onion-ring growth of product material).

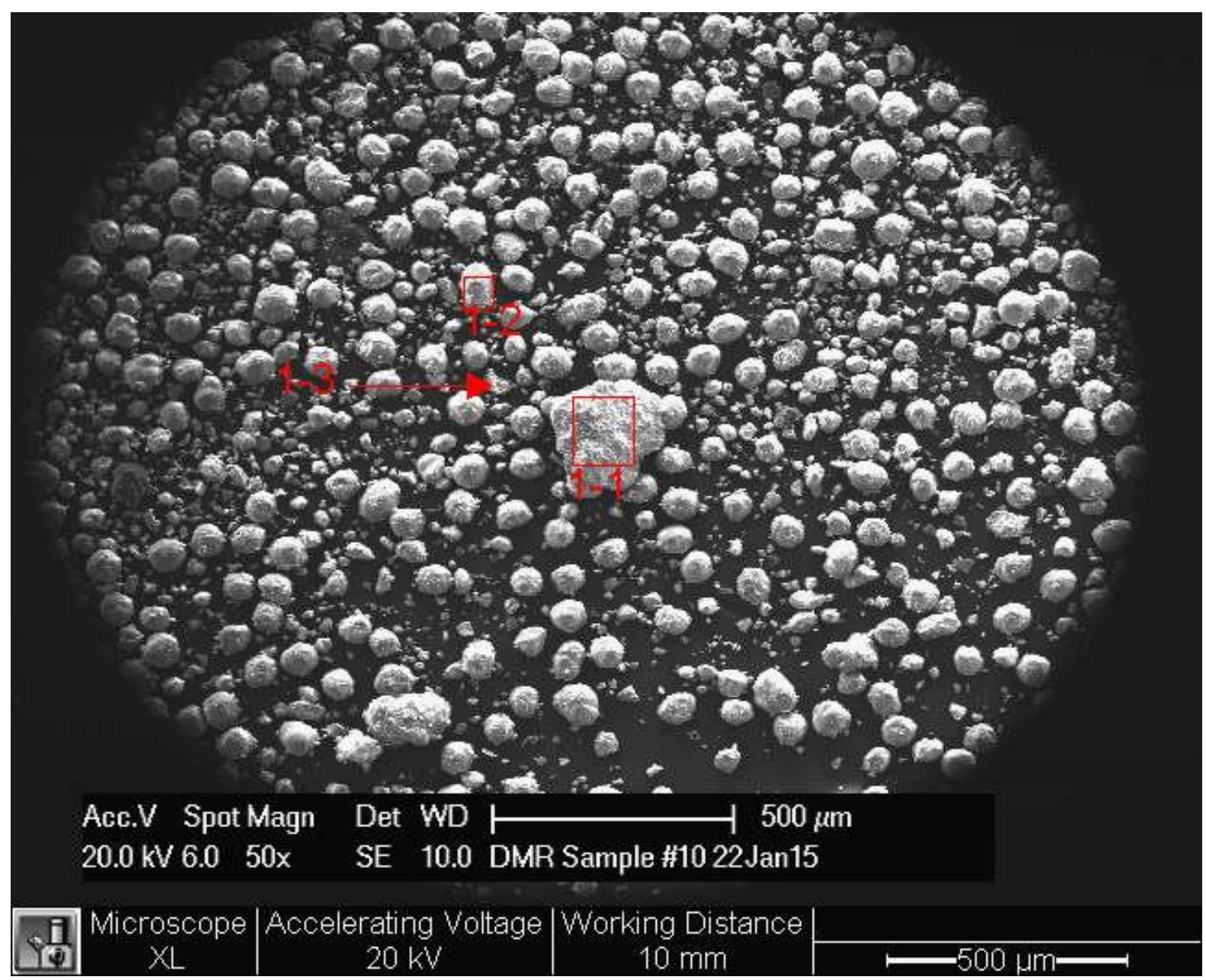

Figure 2-5. SEM photograph of DMR bed removed after shutdown (sampled on January 22, 2015), at 50x magnification. 


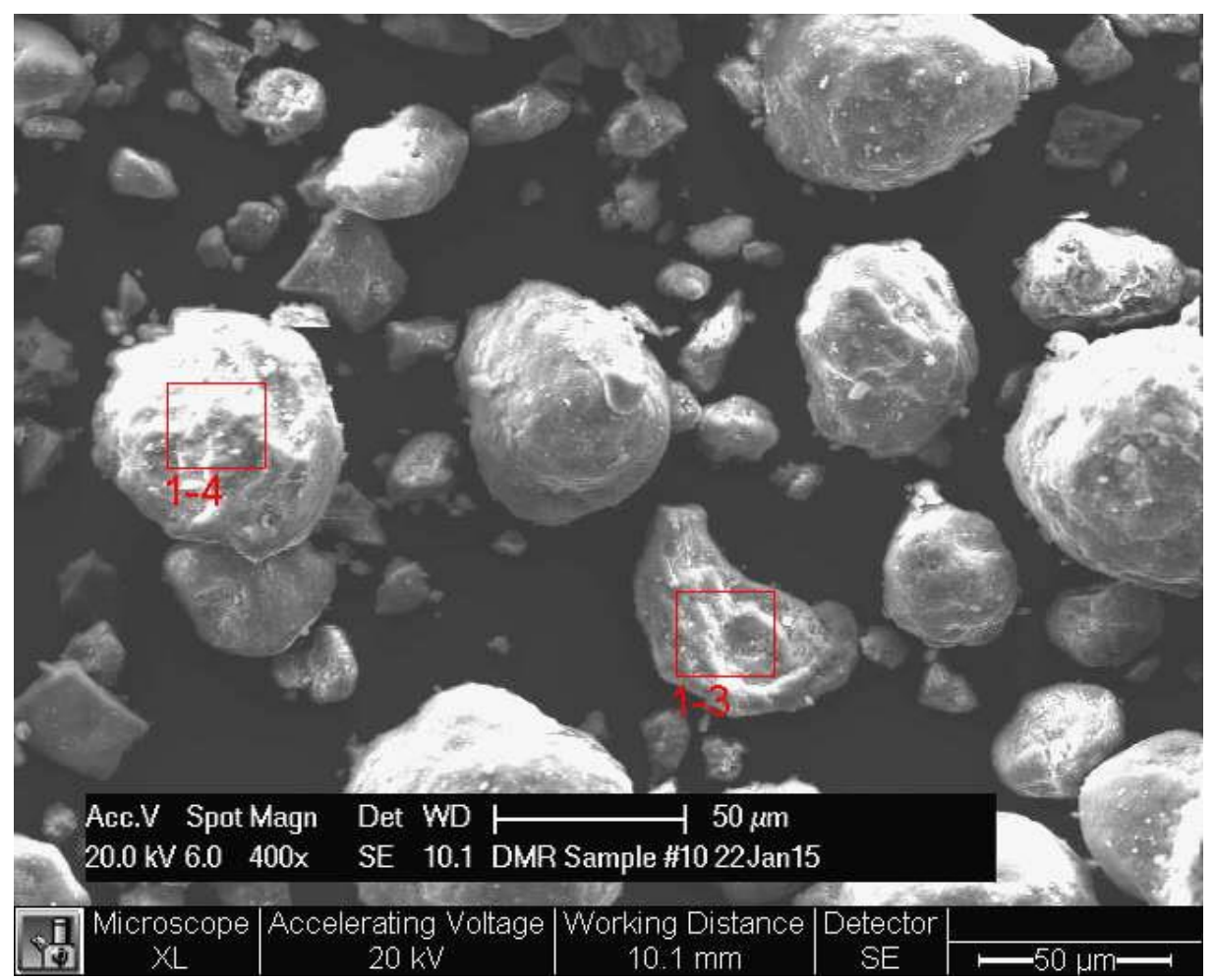

Figure 2-6. SEM photograph of DMR bed removed after shutdown (sampled on January 22, 2015), at 400x magnification.

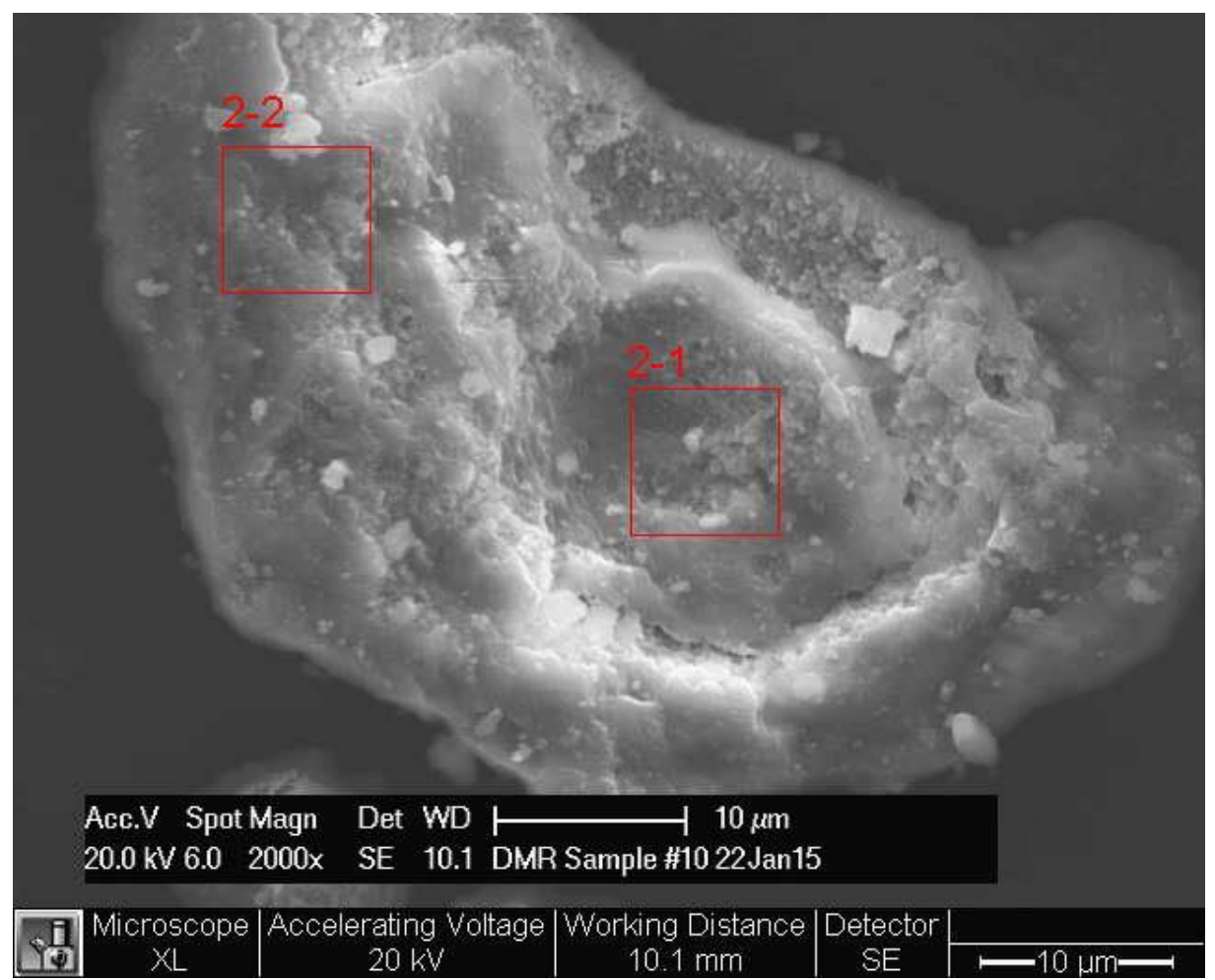

Figure 2-7. SEM photograph of DMR bed removed after shutdown (sampled on January 22, 2015), at 2,000x magnification. 
Table 2-4. Elemental analysis from SEM/EDS for the DMR bed removed after shutdown (sampled on January 22, 2015).

\begin{tabular}{|c|c|c|c|c|c|c|c|}
\hline \multirow[b]{2}{*}{ Element } & \multicolumn{7}{|c|}{ Composition, wt\% } \\
\hline & $\begin{array}{c}\text { Area scan } \\
1-1\end{array}$ & $\begin{array}{c}\text { Area scan } \\
1-2\end{array}$ & $\begin{array}{c}\text { Area scan } \\
1-3 \\
\end{array}$ & $\begin{array}{c}\text { Area scan } \\
1-4 \\
\end{array}$ & $\begin{array}{c}\text { Area scan } \\
2-1\end{array}$ & $\begin{array}{c}\text { Area scan } \\
2-2 \\
\end{array}$ & $\begin{array}{c}\text { Sample } \\
\text { averages } \\
\text { excluding } \\
\text { coal }\end{array}$ \\
\hline C & 14.52 & 18.17 & 17.74 & 16.5 & 14.67 & 13.43 & 15.84 \\
\hline 0 & 38.83 & 39.18 & 39.46 & 37.16 & 37.28 & 39.19 & 38.52 \\
\hline $\mathrm{Na}$ & 25.85 & 23.75 & 26.26 & 26.54 & 26.37 & 27.9 & 26.11 \\
\hline $\mathrm{Al}$ & 16.7 & 15.36 & 12.27 & 14.39 & 15.28 & 15.12 & 14.85 \\
\hline $\mathrm{Si}$ & 1.04 & 0.9 & 0.6 & 0.7 & 0.65 & 0.64 & 0.76 \\
\hline$S$ & 0.73 & 0.62 & 0.98 & 1.23 & 1.49 & 1.09 & 1.02 \\
\hline $\mathrm{Cl}$ & 0 & 0 & 0 & 0 & 0 & 0 & 0.00 \\
\hline K & 2.33 & 2.01 & 2.69 & 3.48 & 4.26 & 2.63 & 2.90 \\
\hline $\mathrm{Fe}$ & 0 & 0 & 0 & 0 & 0 & 0 & 0.00 \\
\hline $\mathrm{Zn}$ & 0 & 0 & 0 & 0 & 0 & 0 & 0.00 \\
\hline Total & 100.00 & 99.99 & 100.00 & 100.00 & 100.00 & 100.00 & 100.00 \\
\hline
\end{tabular}




\section{PARTICLE SIZE ANALYSES}

Particle size measurements were performed on selected DMR, PGF, CRR, and OGF samples. Two analysis methods were used. When the particles were considered large enough and not subject to potential agglomeration due to static or other cohesive forces, then sieve tray analyses were performed using sieve trays according to ASTM D4749 "Standard Test Method for Performing the Sieve Analysis of Coal and Designating Coal Size" or equivalent. When the SEM micrographs indicated that the particles were small, with significant fractions under 10-100 microns, or that the particles appeared cohesive due to particle shape or clumping, then the particle size was estimated using particle size estimating and counting during the SEM analysis. This method of estimating particle size is semi-quantitative, but might not be as subject to bias due to particle agglomerations as the sieve tray method, because this method allows counting of individual particles down to about 1 micron in size, even if they are clumped together with other particles.

These particle size analyses are shown in Table 3-1. The harmonic mean particle diameter (HMPD) and mass mean particle diameter MMPD) of the DMR bed product particles are on the order of one-fifth to one-third of the size of the 40/80 (177-420 micron nominal size range) bauxite starting bed. The two different methods of particle size measurement agreed within about 15-20\% for the DMR bed sample collected from drums 3 and 5 on January 13, 2015.

The one analysis of the PGF solids indicates that the PGF solids averaged on the order of onefourth to one-half of the average particle size of the DMR product, not surprising since the PGF solids represent material that elutriated from the DMR.

Two CRR bed samples were analyzed.

The average particle size of the OGF solids was estimated for one sample.

Table 3-1. Particle size analysis results for DMR, PGF, CRR, and OGF samples.

\begin{tabular}{|l|c|c|c|c|}
\hline \multirow{2}{*}{\multicolumn{1}{c|}{ Sample }} & \multicolumn{4}{c|}{ Mean particle size, micron } \\
\cline { 2 - 5 } & \multicolumn{2}{c|}{ Sieve tray } & \multicolumn{1}{c|}{ SEM estimate } \\
\cline { 2 - 5 } & HMPD & MMPD & HMPD & MMPD \\
\hline DMR 40/80 bauxite 24Jan15 & 396 & 413 & --- & --- \\
\hline DMR bed 2Jan15 & --- & --- & 68 & 98 \\
\hline DMR bed Jan 13 2015 drums 3,5 & 119 & 140 & 107 & 172 \\
\hline DMR bed media 22Jan15 & 69 & 92 & --- & --- \\
\hline PGF solids 2Feb15 & --- & --- & 27 & 39 \\
\hline CRR bed media Jan. 18, 2015 & 502 & 673 & --- & --- \\
\hline CRR bed media Jan. 22, 2015 & 491 & 692 & --- & --- \\
\hline OGF drums 1-5 19Jan15 & --- & --- & 65 & 83 \\
\hline \multicolumn{5}{|c|}{ [dmr sample psd, eds analysis 9feb15.xIsx]sieve analysis } \\
\hline
\end{tabular}

Figure 3-1 shows the distribution of particle sizes found in the two CRR bed samples. As shown in the figure, both bed media samples exhibited bi-modal distributions. 

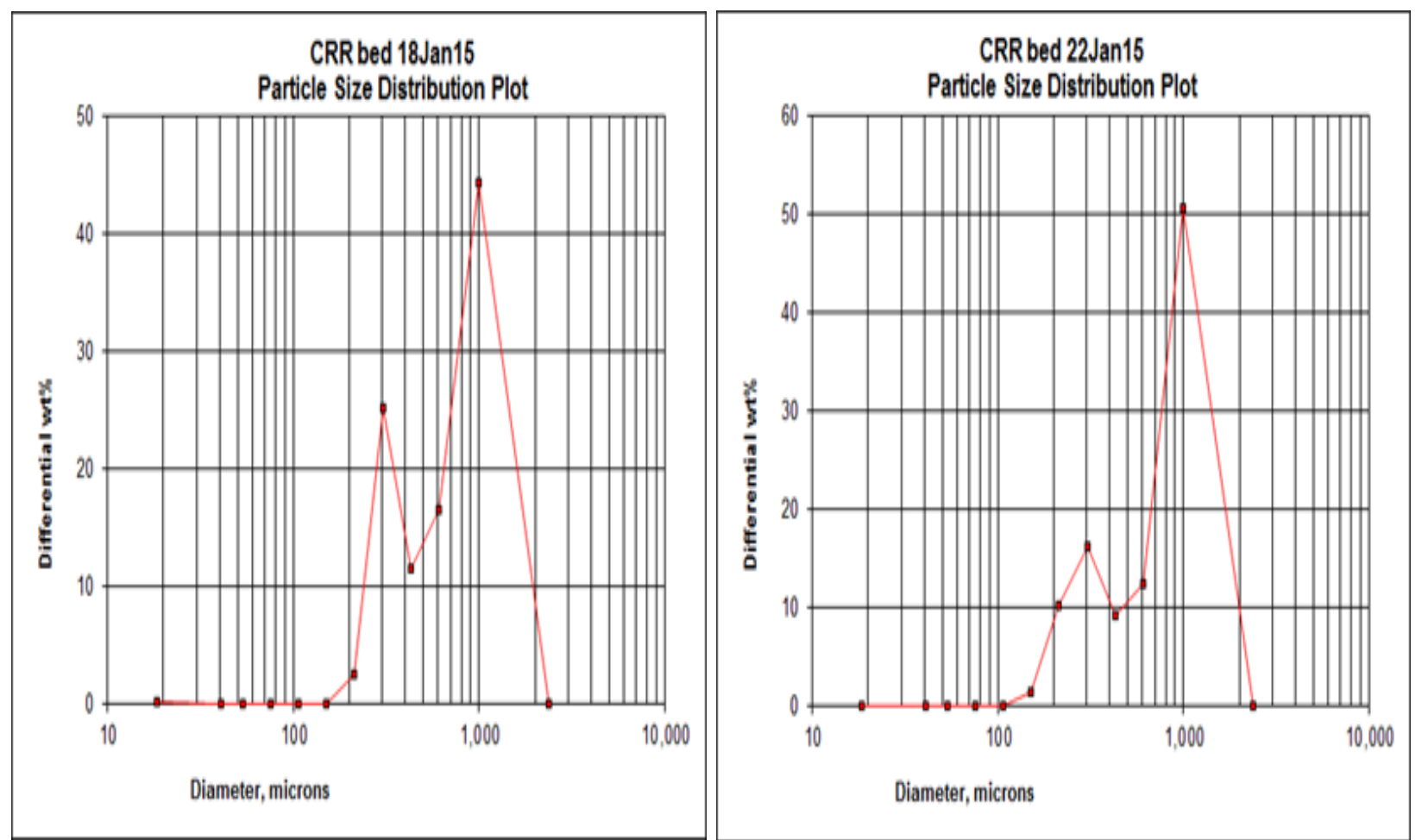

Figure 3-1. Particle-size distribution of CRR bed samples removed after Test Period 7 of TI-102 - Part 2, testing. 


\section{DMR WALL AND AUGER SCALE SEM/EDS ANALYSES}

Samples of the DMR wall and auger scale were analyzed by SEM/EDS analysis.

\subsection{DMR Wall Scale EDS Analyses}

The elemental compositions from EDS for the DMR wall scale are shown in Tables 4-1 through 44. These tables provide composition measurements for the mixed average wall scale composition (from a ground sample), the black-colored outer wall that was adhered to the DMR vessel wall, the white inner portion, and the black inside surface of the scale that faced the DMR bed media. These different regions of the wall scale were analyzed to determine if there are any elemental composition gradients through the thickness of the wall scale from the side of the scale that faces the DMR bed media to the side of the scale that faces the DMR vessel wall.

Figure 4-1 shows the fractured surface of the white inner material in the wall scale is shown in Figure 4-3. Glued-together particles of the bed product are visible. At least two layers are evident. The compositions of each of those layers are shown in Table 4-3.

Table 4-1. Elemental analysis from SEM/EDS for the Jan. 13, 2015 DMR wall scale sample (ground to obtain better averages).

\begin{tabular}{|c|r|r|r|r|r|r|r|}
\hline & \multicolumn{7}{|c|}{ Composition, wt\% } \\
\cline { 2 - 9 } & & & & & & $\begin{array}{c}\text { Point 6 } \\
\text { (coal }\end{array}$ & \\
Element & Point 1 & Point 2 & Point 3 & Point 4 & Point 5 & particle) & Averages \\
\hline $\mathrm{C}$ & 18.46 & 10.79 & 14.40 & 67.28 & 16.01 & 86.15 & $\mathbf{2 5 . 3 9}$ \\
\hline $\mathrm{O}$ & 39.42 & 33.83 & 37.14 & 20.80 & 27.61 & 12.87 & $\mathbf{3 1 . 7 6}$ \\
\hline $\mathrm{Na}$ & 23.90 & 26.51 & 19.59 & 5.81 & 13.47 & 0.60 & $\mathbf{1 7 . 8 6}$ \\
\hline $\mathrm{Al}$ & 9.50 & 21.63 & 13.95 & 2.60 & 7.13 & 0.18 & $\mathbf{1 0 . 9 6}$ \\
\hline $\mathrm{Si}$ & 1.88 & 3.39 & 1.32 & 0.84 & 2.33 & 0.07 & $\mathbf{1 . 9 5}$ \\
\hline $\mathrm{S}$ & 0.70 & 0.24 & 2.07 & 0.22 & 0.72 & 0.00 & $\mathbf{0 . 7 9}$ \\
\hline $\mathrm{Cl}$ & 0.00 & 0.00 & 0.00 & 0.00 & 0.00 & 0.00 & $\mathbf{0 . 0 0}$ \\
\hline $\mathrm{K}$ & 6.13 & 3.61 & 11.54 & 2.45 & 29.75 & 0.06 & $\mathbf{1 0 . 7 0}$ \\
\hline $\mathrm{Fe}$ & 0 & 0 & 0 & 0 & 2.98 & 0.07 & $\mathbf{0 . 6 0}$ \\
\hline Zn & 0 & 0 & 0 & 0 & 0 & 0 & $\mathbf{0 . 0 0}$ \\
\hline Total & 99.99 & 100.00 & 100.01 & 100.00 & 100.00 & 100.00 & $\mathbf{1 0 0 . 0 0}$ \\
\hline [dmr sample psd, eds analysis 9feb15_150302kmr check.xlsx]EDS wall scale 13jan15 \\
\hline
\end{tabular}

Table 4-2. Elemental analysis from SEM/EDS for the Jan. 13, 2015 DMR wall scale sample (black outside adhered to metal wall).

\begin{tabular}{|c|c|c|c|c|}
\hline \multirow[b]{2}{*}{ Element } & \multicolumn{4}{|c|}{ Composition, wt\% } \\
\hline & $\begin{array}{c}\text { Area } \\
\text { scan } 10- \\
1\end{array}$ & $\begin{array}{c}\text { Area } \\
\text { scan 10- } \\
2\end{array}$ & $\begin{array}{c}\text { Area } \\
\text { scan } 10 \\
3\end{array}$ & Averages \\
\hline $\mathrm{C}$ & 47.24 & 34.65 & 36.96 & 39.62 \\
\hline $\mathrm{O}$ & 28.85 & 36.09 & 34.92 & 33.29 \\
\hline $\mathrm{Na}$ & 10.15 & 13.85 & 12.85 & 12.28 \\
\hline $\mathrm{Al}$ & 6.96 & 8.38 & 8.23 & 7.86 \\
\hline $\mathrm{Si}$ & 0.96 & 1.11 & 1.06 & 1.04 \\
\hline$S$ & 0.47 & 0.61 & 0.57 & 0.55 \\
\hline $\mathrm{Cl}$ & 0.84 & 0.72 & 0.77 & 0.78 \\
\hline K & 3.72 & 3.82 & 3.79 & 3.78 \\
\hline $\mathrm{Fe}$ & 0.81 & 0.78 & 0.86 & 0.82 \\
\hline $\mathrm{Zn}$ & 0 & 0 & 0 & 0.00 \\
\hline Total & 100.00 & 100.01 & 100.01 & 100.01 \\
\hline
\end{tabular}


Table 4-3. Elemental analysis from SEM/EDS for the Jan. 13, 2015 DMR wall scale sample (white inner portion).

\begin{tabular}{|c|c|c|c|c|c|c|c|}
\hline \multirow[b]{2}{*}{ Element } & \multicolumn{7}{|c|}{ Composition, wt\% } \\
\hline & \begin{tabular}{|c} 
Area \\
scan 1- \\
1 \\
\end{tabular} & $\begin{array}{c}\text { Area } \\
\text { scan 1- } \\
2 \\
\end{array}$ & $\begin{array}{c}\text { Area } \\
\text { scan 1- } \\
3 \\
\end{array}$ & $\begin{array}{c}\text { Area } \\
\text { scan 2- } \\
1 \\
\end{array}$ & $\begin{array}{c}\text { Area } \\
\text { scan 2- } \\
2 \\
\end{array}$ & $\begin{array}{c}\text { Area scan 2-3 } \\
\text { (coal ash } \\
\text { impurity) } \\
\end{array}$ & Averages \\
\hline$C$ & 23.01 & 23.59 & 23.66 & 23.67 & 23.30 & 32.92 & 23.45 \\
\hline 0 & 38.01 & 37.22 & 38.17 & 38.13 & 36.99 & 18.88 & 37.70 \\
\hline $\mathrm{Na}$ & 20.40 & 20.05 & 19.85 & 19.46 & 20.43 & 15.68 & 20.04 \\
\hline $\mathrm{Al}$ & 13.21 & 12.57 & 13.66 & 13.94 & 13.09 & 7.80 & 13.29 \\
\hline Si & 1.00 & 1.03 & 0.78 & 1.01 & 0.94 & 0.84 & 0.95 \\
\hline $\mathrm{S}$ & 0.82 & 0.91 & 0.75 & 0.75 & 0.86 & 1.93 & 0.82 \\
\hline $\mathrm{Cl}$ & 0.06 & 0.13 & 0.06 & 0.06 & 0.10 & 0.55 & 0.08 \\
\hline K & 3.24 & 4.14 & 2.79 & 2.69 & 3.96 & 6.01 & 3.36 \\
\hline $\mathrm{Fe}$ & 0.27 & 0.36 & 0.28 & 0.30 & 0.32 & 0.58 & 0.31 \\
\hline $\mathrm{Zn}$ & 0 & 0 & 0 & 0 & 0 & 14.83 & 0.00 \\
\hline Total & 100.02 & 100.00 & 100.00 & 100.01 & 99.99 & 100.02 & 100.00 \\
\hline
\end{tabular}

Table 4-4. Elemental analysis from SEM/EDS for the Jan. 13, 2015 DMR wall scale sample (black inside facing bed).

\begin{tabular}{|c|rrr|r|}
\hline & \multicolumn{4}{|c|}{ Composition, wt\% } \\
\cline { 2 - 5 } Element & & & & \multicolumn{1}{|c|}{1} \\
\hline $\mathrm{C}$ & 28.60 & 31.36 & 38.32 & $\mathbf{3 2 . 7 6}$ \\
$\mathrm{O}$ & 39.33 & 37.52 & 34.01 & $\mathbf{3 6 . 9 5}$ \\
$\mathrm{Na}$ & 16.84 & 15.36 & 13.78 & $\mathbf{1 5 . 3 3}$ \\
$\mathrm{Al}$ & 8.56 & 8.53 & 7.80 & $\mathbf{8 . 3 0}$ \\
$\mathrm{Si}$ & 1.10 & 1.15 & 1.24 & $\mathbf{1 . 1 6}$ \\
\hline $\mathrm{S}$ & 0.58 & 0.61 & 0.53 & $\mathbf{0 . 5 7}$ \\
$\mathrm{Cl}$ & 0.33 & 0.42 & 0.52 & $\mathbf{0 . 4 2}$ \\
\hline $\mathrm{K}$ & 3.67 & 3.99 & 2.98 & $\mathbf{3 . 5 5}$ \\
\hline $\mathrm{Fe}$ & 0.99 & 1.06 & 0.81 & $\mathbf{0 . 9 5}$ \\
\hline $\mathrm{Zn}$ & 0 & 0 & 0 & $\mathbf{0 . 0 0}$ \\
\hline Total & 100.00 & 100.00 & 99.99 & $\mathbf{1 0 0 . 0 0}$ \\
\hline
\end{tabular}




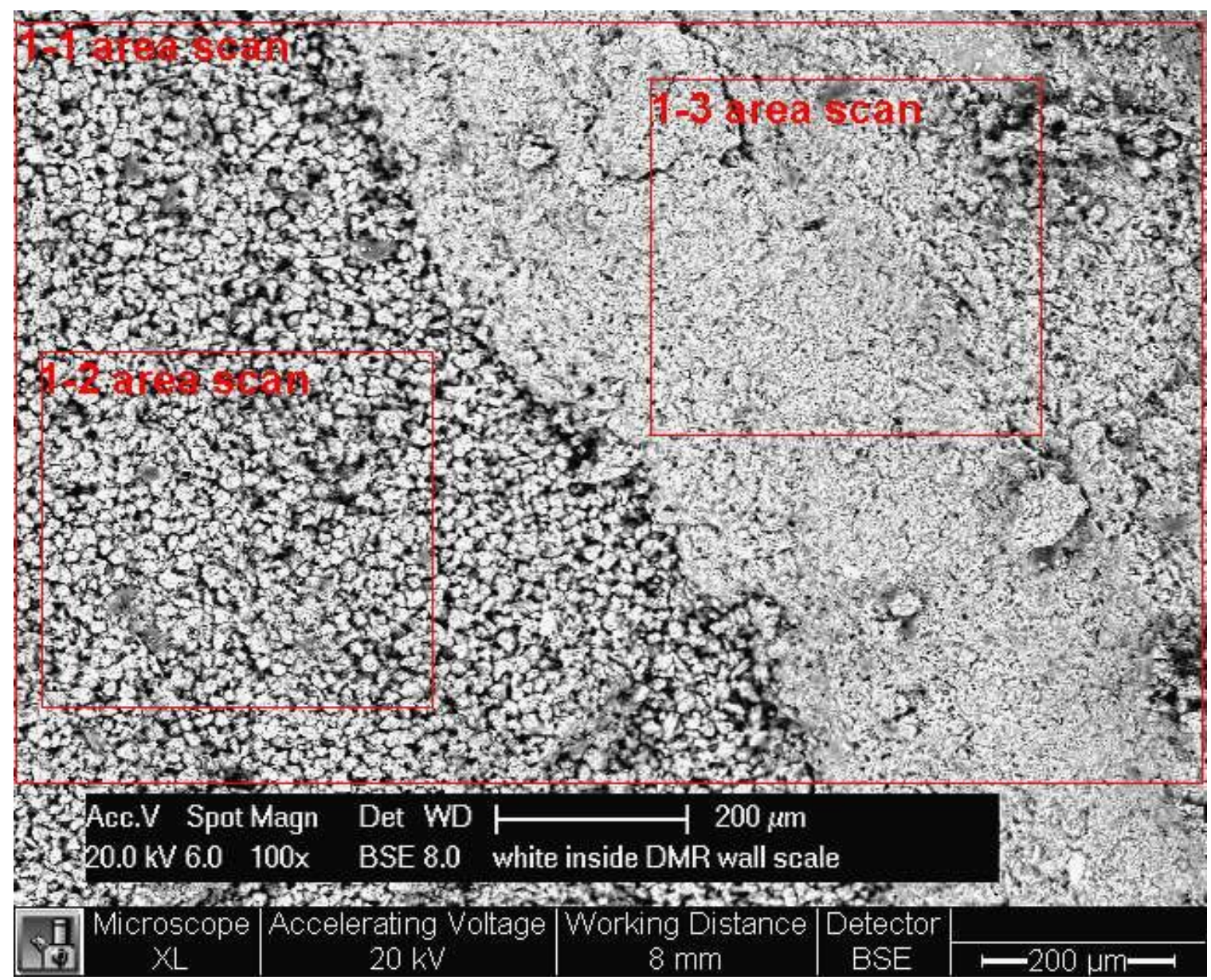

Figure 4-1. SEM photograph of a fractured inner surface of the DMR wall scale magnified 100x.

Figure 4-2 shows how these different wall scale measurements compare. The $\mathrm{C}$ concentration is higher, and $\mathrm{Na}$ and $\mathrm{Al}$ are somewhat depleted, at the outer side of scale that faced the DMR vessel wall. Depleted $\mathrm{Na}$ at the side of the scale facing the vessel wall is consistent with a theory that wall scale formation began growing at as soon as the bed turnover started, when simulated waste feed was started.

Levels of $\mathrm{K}$ in each of the three regions in the wall scale are not consistent with the average $\mathrm{K}$ value measured in a ground sample of wall scale. Perhaps grinding the sample enabled exposure of more $\mathrm{K}$ to the EDS analysis than was detectable at the wall scale surfaces. The EDS analysis normally only penetrates a few microns into the surface of a solid particle. Coal ash analyses (if performed) may indicate how much $\mathrm{K}$ is present in the coal ash; but no $\mathrm{K}$ was included in the simulant feed recipe until Batch 2 . If wall scale contains $\mathrm{K}$, it could only have formed after Batch 2 was started on December 24, or from the (expectedly small amount of) $\mathrm{K}$ that in the coal ash. 


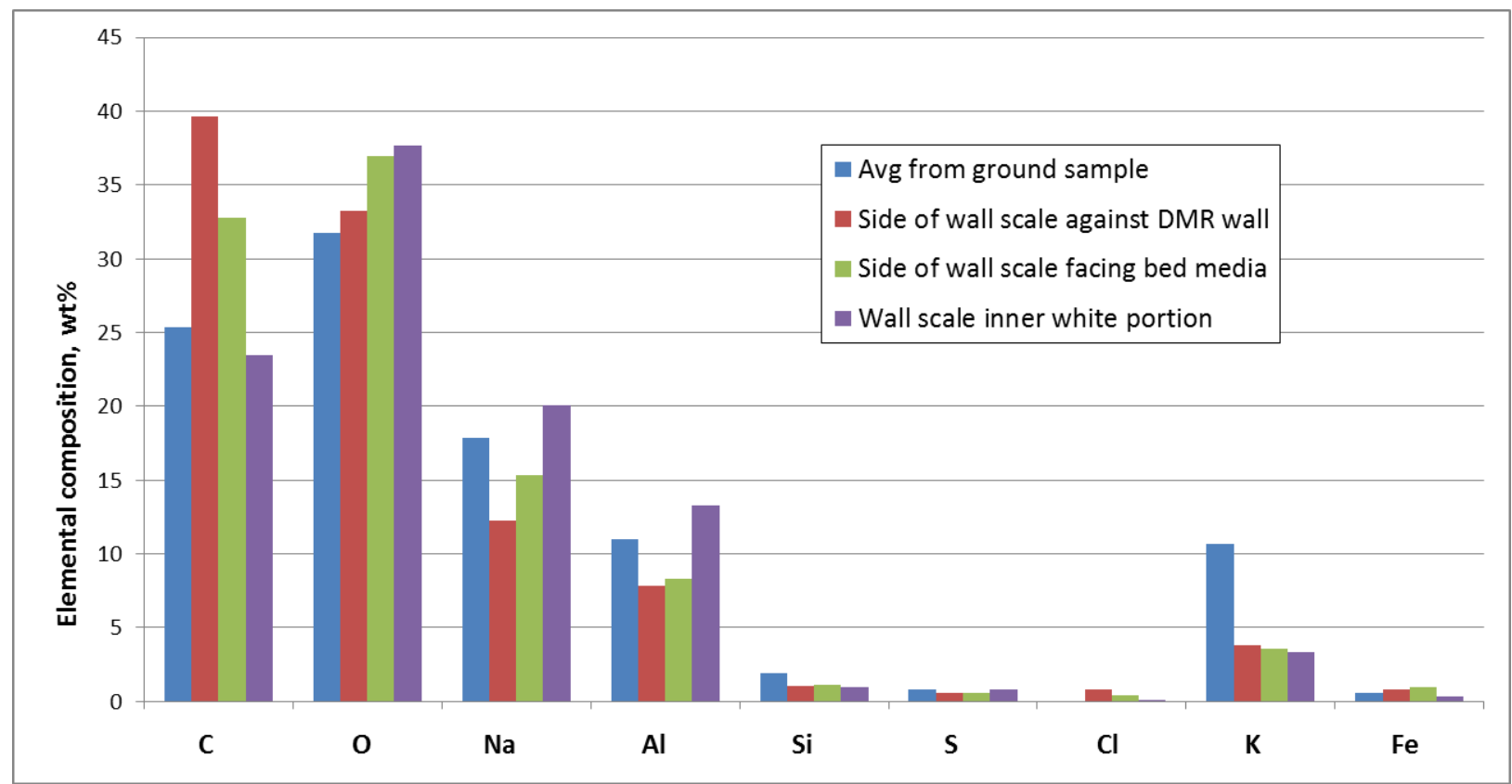

Figure 4-2. Trends of average elemental compositions from EDS for the DMR wall scale.

\subsection{DMR Auger Scale EDS Analyses}

The elemental composition from EDS analysis for the A/G scale sample is shown in Table 4-5 and Figure 4-3. Two regions generally identified by color were analyzed separately. The white portion has lower $\mathrm{C}$ and higher $\mathrm{O}, \mathrm{Na}, \mathrm{Al}$, and $\mathrm{Si}$. $\mathrm{K}$ is approximately equally distributed between the white and black regions.

Table 4-5. EDS compositions of the A/G scale (January 19, 2015 sample).

\begin{tabular}{|c|c|c|c|c|c|c|}
\hline \multirow[b]{4}{*}{ Element } & \multicolumn{5}{|c|}{ White portion } & \\
\hline & \multicolumn{6}{|c|}{ Composition, wt\% } \\
\hline & Point 6- & Point 6- & Point 6- & Point 6- & - Point 6- & \\
\hline & 1 & 2 & 3 & 4 & 5 & Avg. \\
\hline C & 12.22 & 14.08 & 14.64 & 12.22 & 14.35 & 13.50 \\
\hline $\mathrm{O}$ & 36.83 & 36.99 & 38.46 & 38.82 & 39.74 & 38.17 \\
\hline $\mathrm{Na}$ & 26.15 & 26.74 & 22.24 & 17.46 & 27.42 & 24.00 \\
\hline Al & 20.29 & 17.04 & 18.34 & 11.45 & 13.06 & 16.04 \\
\hline $\mathrm{Si}$ & 0.79 & 1.07 & 0.89 & 11.88 & 0.92 & 3.11 \\
\hline$S$ & 0.86 & 0.96 & 1.35 & 0.46 & 1.18 & 0.96 \\
\hline $\mathrm{Cl}$ & 0.15 & 0.07 & 0.08 & 0.01 & 0.05 & 0.07 \\
\hline K & 2.51 & 2.89 & 3.81 & 7.16 & 3.14 & 3.90 \\
\hline $\mathrm{Fe}$ & 0.20 & 0.17 & 0.19 & 0.53 & 0.13 & 0.24 \\
\hline $\mathrm{Zn}$ & 0.00 & 0.00 & 0.00 & 0.00 & 0.00 & 0.00 \\
\hline Total & 100.00 & 100.01 & 100.00 & 99.99 & 99.99 & 100.00 \\
\hline
\end{tabular}

\begin{tabular}{|c|r|r|r|r|r|}
\hline \multicolumn{7}{|c|}{ Black portion } \\
\hline & \multicolumn{5}{|c|}{ Composition, wt\% } \\
\cline { 2 - 6 } & Area & Area & Area & Area & \\
& scan 3- & scan 3- & scan 4- & scan 5- & \\
\hline Element & 1 & 2 & 1 & \multicolumn{1}{|c|}{1} & Avg. \\
\hline $\mathrm{C}$ & 24.61 & 21.79 & 25.42 & 21.12 & $\mathbf{2 3 . 2 4}$ \\
\hline $\mathrm{O}$ & 32.32 & 32.54 & 32.66 & 33.44 & $\mathbf{3 2 . 7 4}$ \\
$\mathrm{Na}$ & 21.73 & 22.55 & 21.47 & 23.17 & $\mathbf{2 2 . 2 3}$ \\
\hline $\mathrm{Al}$ & 11.69 & 12.30 & 12.11 & 13.56 & $\mathbf{1 2 . 4 2}$ \\
$\mathrm{Si}$ & 1.62 & 1.86 & 1.48 & 1.49 & $\mathbf{1 . 6 1}$ \\
$\mathrm{S}$ & 1.40 & 1.55 & 1.18 & 1.32 & $\mathbf{1 . 3 6}$ \\
\hline $\mathrm{Cl}$ & 0.28 & 0.36 & 0.15 & 0.16 & $\mathbf{0 . 2 4}$ \\
\hline $\mathrm{K}$ & 4.39 & 4.85 & 4.58 & 4.86 & $\mathbf{4 . 6 7}$ \\
\hline $\mathrm{Fe}$ & 1.69 & 1.69 & 0.95 & 0.88 & $\mathbf{1 . 3 0}$ \\
\hline $\mathrm{Zn}$ & 0.26 & 0.51 & 0.00 & 0.00 & $\mathbf{0 . 1 9}$ \\
\hline Total & 99.99 & 100.00 & 100.00 & 100.00 & $\mathbf{1 0 0 . 0 0}$ \\
\hline & & & &
\end{tabular}

\begin{tabular}{|c|c|}
\hline \multicolumn{2}{|c|}{$\begin{array}{c}\text { Average } \mathrm{A} / \mathrm{G} \text { wall } \\
\text { scale composition }\end{array}$} \\
\hline Element & $\begin{array}{c}\text { Overall } \\
\text { avg. } \\
\text { comp., } \\
\text { wt\% }\end{array}$ \\
\hline $\mathrm{C}$ & $\mathbf{1 8 . 3 7}$ \\
$\mathrm{O}$ & $\mathbf{3 5 . 4 5}$ \\
$\mathrm{Na}$ & $\mathbf{2 3 . 1 2}$ \\
$\mathrm{Al}$ & $\mathbf{1 4 . 2 3}$ \\
$\mathrm{Si}$ & $\mathbf{2 . 3 6}$ \\
$\mathrm{S}$ & $\mathbf{1 . 1 6}$ \\
$\mathrm{Cl}$ & $\mathbf{0 . 1 5}$ \\
$\mathrm{K}$ & $\mathbf{4 . 2 9}$ \\
$\mathrm{Fe}$ & $\mathbf{0 . 7 7}$ \\
$\mathrm{Zn}$ & $\mathbf{0 . 1 0}$ \\
\hline Total & $\mathbf{1 0 0 . 0 0}$ \\
\hline
\end{tabular}




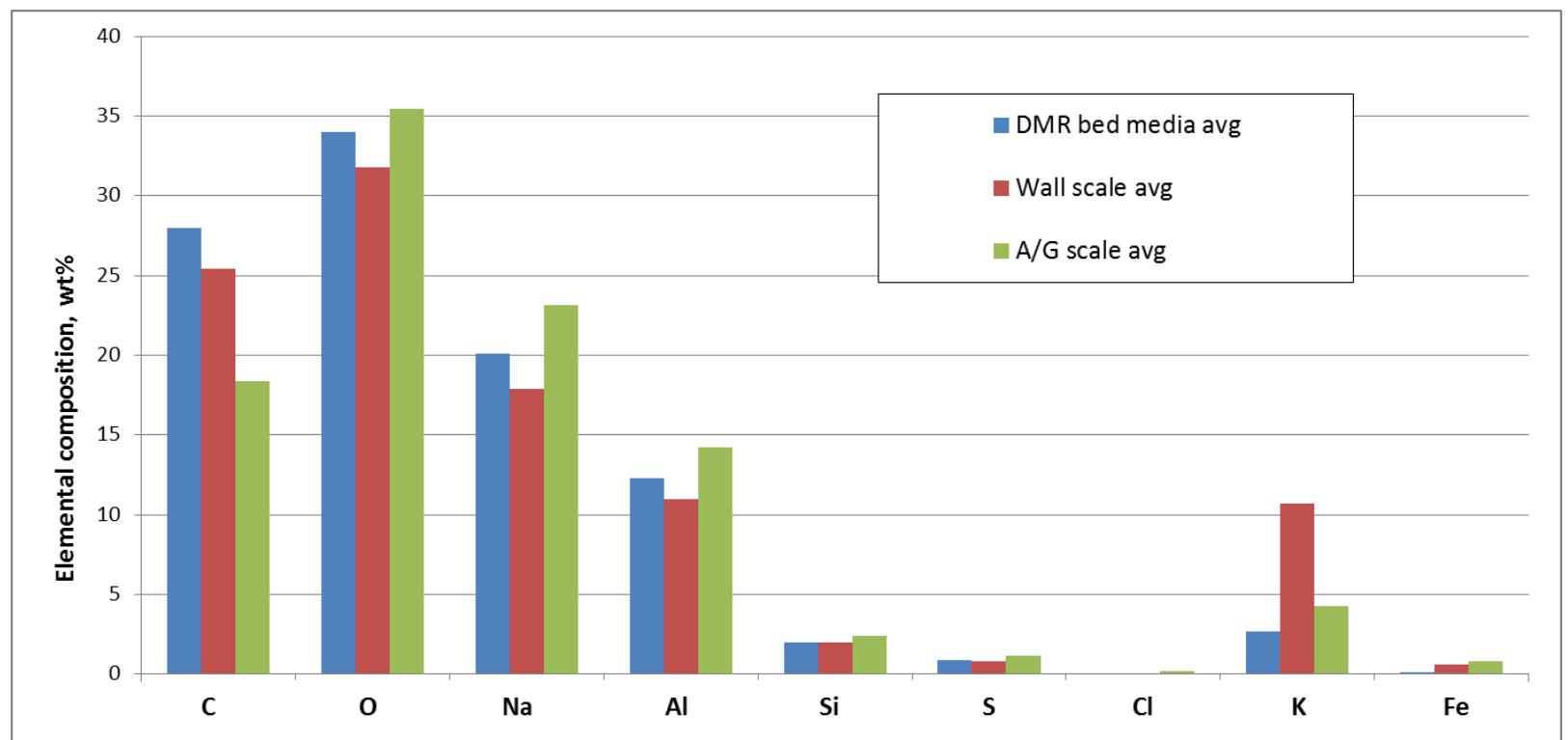

Figure 4-3. Comparisons of the EDS compositions for the white and black regions of the A/G scale (January 19, 2015 sample).

\subsection{Comparison of DMR bed media, wall scale, and auger scale EDS analyses}

Figure 4-4 and Table 4-6 compare the EDS elemental analysis for the DMR bed product, wall scale, and auger scale samples. This figure shows the average analyses of the multiple bed product samples, not including the coal or bauxite particles found in those analyses.

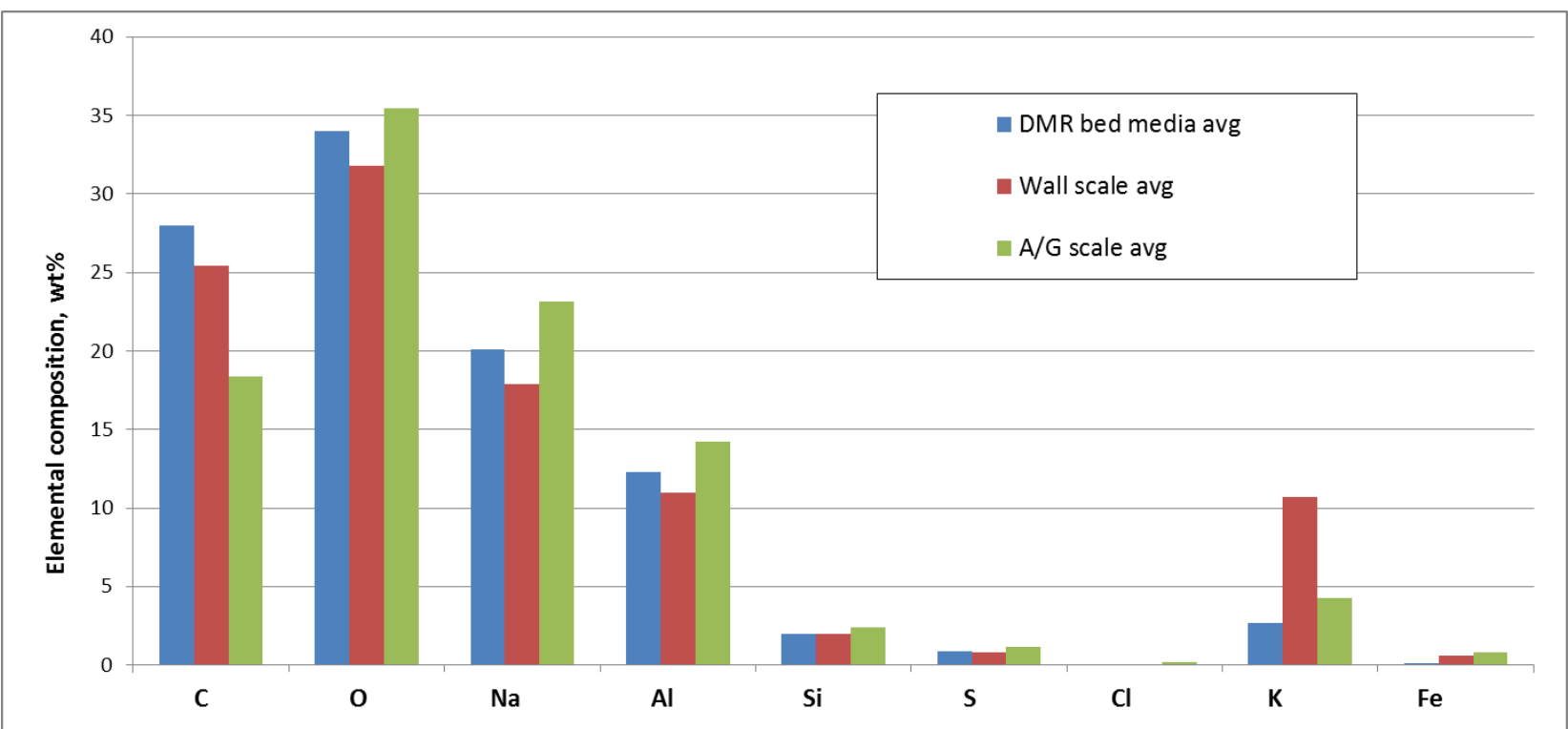

Figure 4-4. Comparison of average elemental compositions from EDS for the DMR bed product, the wall scale, and the $\mathrm{A} / \mathrm{G}$ scale. 
Based on the EDS analyses, these materials all contain the same elements.

- The DMR product samples average higher $\mathrm{C}$ and the $\mathrm{A} / \mathrm{G}$ scale sample has the lowest $\mathrm{C}$

- Oxygen and Na concentrations in the wall and $\mathrm{A} / \mathrm{G}$ scale samples range within about $15 \%$ of the bed samples

- $\quad$ The wall and $\mathrm{A} / \mathrm{G}$ scale samples have up to $30 \%$ higher $\mathrm{Al}$

- The wall and $\mathrm{A} / \mathrm{G}$ scale samples have up to $21 \%$ higher $\mathrm{Si}$

- The wall scale has $9 \%$ lower $\mathrm{S}$, but the $\mathrm{A} / \mathrm{G}$ scale has $34 \%$ more $\mathrm{S}$, compared to the DMR product

- The wall scale has about $4 \mathrm{x}$ higher $\mathrm{K}$, and the $\mathrm{A} / \mathrm{G}$ scale has $59 \%$ higher $\mathrm{K}$, compared to the DMR product

- The wall scale has about $6 \mathrm{x}$ higher Fe, and the $\mathrm{A} / \mathrm{G}$ scale has about 8x higher Fe, compared to the DMR product.

Table 4-6. Average EDS compositions of 4 DMR samples, wall scale, and A/G scale.

\begin{tabular}{|c|c|c|c|c|c|c|}
\hline \multirow[b]{2}{*}{ Element } & \multicolumn{3}{|c|}{ Composition, wt\% } & \multirow[b]{2}{*}{$\begin{array}{c}\text { Enrichment } \\
\text { in wall scale } \\
\text { vs average } \\
\text { bed }\end{array}$} & \multirow[b]{2}{*}{$\begin{array}{c}\text { Enrichment } \\
\text { in A/G scale } \\
\text { vs average } \\
\text { bed }\end{array}$} & \multirow[b]{2}{*}{$\begin{array}{c}\text { Comparison, } \\
\text { A/G scale vs } \\
\text { wall scale }\end{array}$} \\
\hline & $\begin{array}{c}\text { 4-sample } \\
\text { DMR } \\
\text { product } \\
\text { averages }\end{array}$ & $\begin{array}{c}\text { Wall } \\
\text { scale } \\
\text { averages }\end{array}$ & $\begin{array}{l}\mathrm{A} / \mathrm{G} \text { scale } \\
\text { averages }\end{array}$ & & & \\
\hline C & 28.01 & 25.39 & 18.37 & 0.91 & 0.66 & 0.72 \\
\hline $\mathrm{O}$ & 34.02 & 31.76 & 35.45 & 0.93 & 1.04 & 1.12 \\
\hline $\mathrm{Na}$ & 20.11 & 17.86 & 23.12 & 0.89 & 1.15 & 1.29 \\
\hline Al & 12.25 & 10.96 & 14.23 & 0.89 & 1.16 & 1.30 \\
\hline $\mathrm{Si}$ & 1.96 & 1.95 & 2.36 & 1.00 & 1.20 & 1.21 \\
\hline$S$ & 0.87 & 0.79 & 1.16 & 0.91 & 1.34 & 1.47 \\
\hline $\mathrm{Cl}$ & 0.00 & 0.00 & 0.15 & --- & --- & --- \\
\hline K & 2.69 & 10.70 & 4.29 & 3.98 & 1.59 & 0.40 \\
\hline $\mathrm{Fe}$ & 0.10 & 0.60 & 0.77 & 6.22 & 8.07 & 1.30 \\
\hline $\mathrm{Zn}$ & 0.00 & 0.00 & 0.10 & --- & --- & --- \\
\hline Total & 100.00 & 100.00 & 100.00 & --- & --- & --- \\
\hline
\end{tabular}

[dmr sample psd, eds analysis 9feb15.xlsx]EDS dmr bed samples 


\section{IWTU SAMPLE SOLUBILITY AND DENSITY}

The DMR bed, wall scale, A/G scale, PGF solids, and OGF solids samples were analyzed for solubility in water and density. The solubility in water results are shown in Table 5-1. This table shows the results of two sets of solubility data - the solubility in room-temperature water followed by hot water, and the solubility in only hot water without an initial test of solubility in room-temperature water.

Solubility in cold (room temperature) and hot water were determined sequentially and then totaled to estimate the total water solubility. The DMR bed sample from January 2, 2015 is only about $44 \mathrm{wt} \%$ soluble in cold and hot water, and only $38 \mathrm{wt} \%$ soluble in hot water only, presumably because of incomplete bed turnover or higher coal levels. The DMR bed sample and the wall scale sample from January 13 , and the A/G scale sample from January 19 , are more soluble, ranging between $66-84 \mathrm{wt} \%$ soluble in cold and then hot water, and $59-72 \%$ in hot water only. These higher solubilities are presumably due to higher bed turnover at the end of the TI-102 test, or to lower coal inventories, especially in the DMR bed sample.

The comparison of the two sets of solubility results indicates that the DMR, wall scale, and A/G scale samples are more soluble in the sequence of cold and hot water solubility tests, compared to hot water only. This might be due to the fact that some compounds and minerals are more soluble in cold water than in hot water.

The hot water solubility of the PGF fines is relatively high at about $59 \mathrm{wt} \%$, consistent with the expectation that the PGF solids are primarily fines of the DMR bed media, which also averaged $59 \mathrm{wt} \%$ hot water solubility.

The hot water solubility of the OGF fines is low, averaging about $6 \mathrm{wt} \%$, presumably because the OGF solids contain mostly fines of insoluble bauxite (that was only about $2 \mathrm{wt} \%$ soluble) and petroleum coke.

Table 5-1. DMR bed, wall scale, and A/G scale sample water solubility test results.

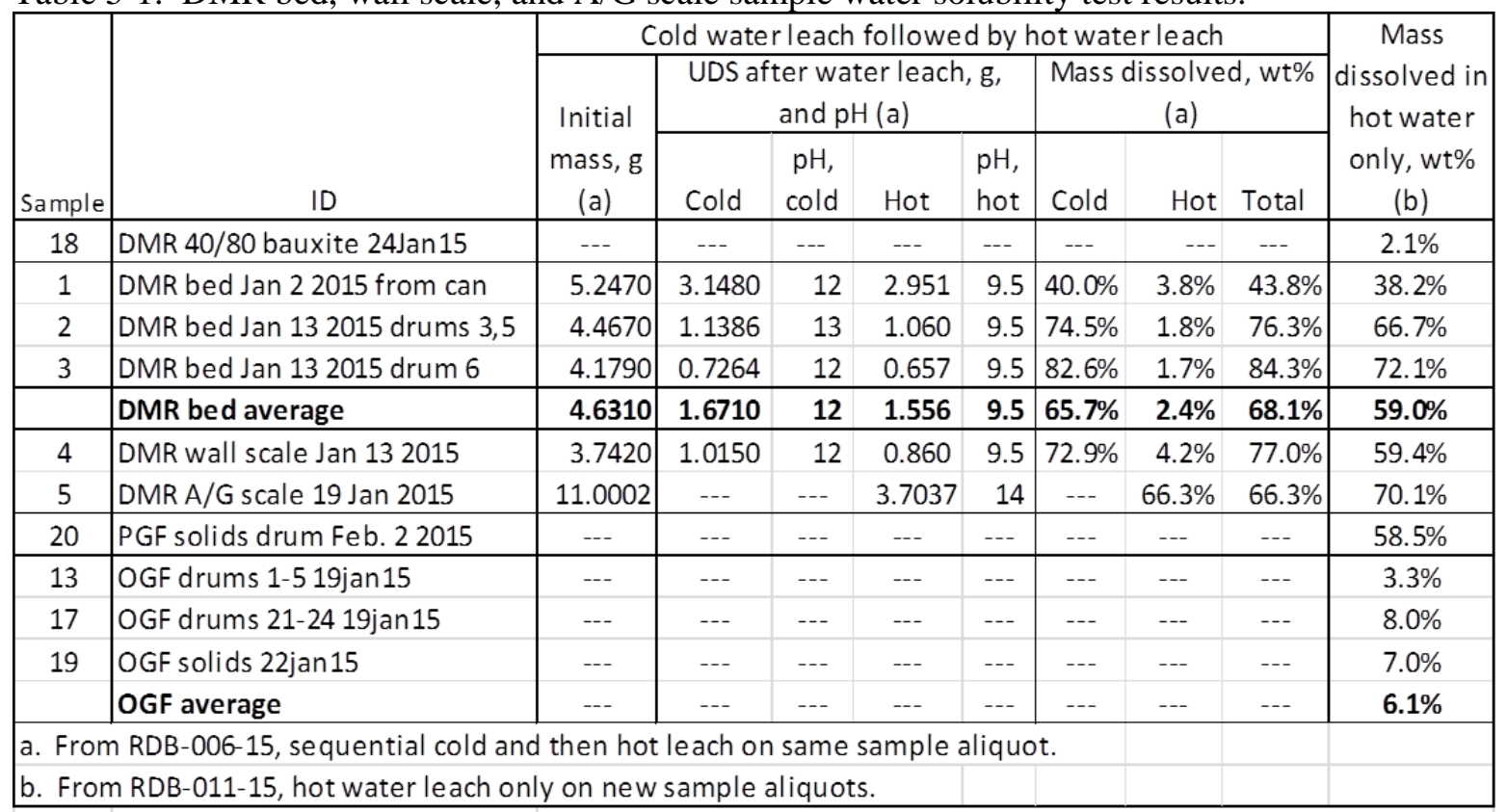

[RDB-006-15 IWTU I on Chromatography nrs16mar15.xIsx]mass loss data

The $\mathrm{pH}$ of the water samples containing the dissolved bed, wall scale, and $\mathrm{A} / \mathrm{G}$ scale material ranged from about 9.5-14. 
The solubility tests showed that both the wall scale and the A/G scale samples appreciably dissolved in water. After about $1 \mathrm{hr}$, much of the sample retained is original shape and size. After about 12 hours, the sample appeared more flaked apart and physically decomposed, and most of the mass was dissolved. The residual undissolved solids (UDS) appeared to be flakes and particles of original sample that crumbled further upon handling.

These results indicate that dissolution by water is a viable DMR vessel cleanout method, although dissolution of large masses of material is likely slowed by mass transfer or kinetics of the dissolution process. Larger particles than the one tested may dissolve more slowly.

The bulk and particle density measurements for IWTU samples are reported in Table 5-2. Acetone was used as the liquid for filling in interstitial space between the product particles for the particle density analysis, because sodium carbonate is not highly soluble in acetone.

Table 5-2. DMR bed sample bulk and particle density.

\begin{tabular}{|c|l|c|c|}
\hline \multirow{2}{*}{ Sample } & \multicolumn{1}{|c|}{ ID } & \multicolumn{2}{|c|}{ Density, gm/cc } \\
\cline { 2 - 4 } & \multicolumn{1}{|c|}{ Tapped bulk } & Particle (a) \\
\hline 18 & DMR 40/80 bauxite 24Jan15 & 2.05 & 3.24 \\
\hline 1 & DMR bed Jan 2 2015 from can & 1.09 & 1.64 \\
\hline 2 & DMR bed Jan 132015 drums 3,5 & 1.39 & 1.89 \\
\hline 3 & DMR bed Jan 132015 drum 6 & 1.39 & 2.30 \\
\hline 10 & DMR bed media 22Jan15 & 1.35 & 2.21 \\
\hline--- & DMR bed average & 1.30 & 2.01 \\
\hline 4 & DMR wall scale Jan 13 2015 & Insufficient sample \\
\hline 5 & DMR A/G scale 19 Jan 2015 & --- & 2.08 \\
\hline 20 & PGF solids drum Feb. 2 2015 & 0.63 & 0.81 \\
\hline 11 & CRR bed media Jan. 18, 2015 & 2.33 & 3.17 \\
\hline 12 & CRR bed media Jan. 22, 2015 & 2.16 & 2.74 \\
\hline--- & CRR average & $\mathbf{2 . 2 5}$ & $\mathbf{2 . 9 5}$ \\
\hline 13 & OGF drums 1-5 19jan15 & 0.45 & 0.73 \\
\hline 17 & OGF drums 21-24 19jan15 & 0.48 & 0.69 \\
\hline 19 & OGF solids 22jan15 & 0.44 & 0.62 \\
\hline--- & OGF average & 0.45 & 0.68 \\
\hline $\begin{array}{l}\text { a. The bauxite particle densities trend Iower than expected densities } \\
\text { of about 3.5 g/cc from vendor literature. }\end{array}$ \\
\hline
\end{tabular}




\section{ELEMENTAL COMPOSITIONS FROM WET CHEMISTRY ANALYSIS}

Elemental compositions were semiquantitatively determined using SEM/EDS because that is a relatively fast method compared to digestions and wet chemistry analysis of the elements in the samples. Digestion and wet chemistry analysis is expected to provide more accurate and more sensitive elemental analysis results because it is not biased by the carbon coating used for SEM/EDS analyses, it has better detection limits, and it provides a more representative average composition since it is not limited to a depth of just a few microns into a particle. Wet chemistry analysis can be biased unless digestions are complete, with no residual undissolved material, so considerable time and multiple digestion methods are sometimes needed for accurate wet chemistry analysis. While SEM/EDS analysis can be done as soon after sample collection as the SEM can be scheduled (often within 1 week of sample collection), the wet chemistry analyses often require over 3-4 weeks due to the duration of sequential analytical work needed for analysis.

\subsection{IWTU Sample Anion Concentrations}

The ITWU sample anion concentrations were determined two ways. First, aliquots of DMR bed, wall scale, and A/G scale samples were tested by dissolution in cold (room temperature) water. The remaining UDS was filtered from the dissolved solution, and re-dissolved in hot water. The two dissolved solutions from these two sequential dissolutions were analyzed for dissolved anions by ion chromatography (IC). The results of these two sequential dissolutions are shown in Table 6-1. Fluoride, $\mathrm{NO}_{2}$, and $\mathrm{Br}$ were largely not detectable. Chloride, $\mathrm{SO}_{4}, \mathrm{NO}_{3}$, and $\mathrm{PO}_{4}$ were detectable, although $\mathrm{NO}_{3}$ and $\mathrm{PO}_{4}$ levels were low, ranging on the order of $0.01 \mathrm{wt} \%$ or lower. Carbonate was not included in this analysis. Generally more than $1 / 2$ of the amount of each anion detected was dissolved in the cold water leach. This analysis did not detect any amounts of these anions that were not soluble in cold or hot water. 
Table 6-1. Anion concentrations in the DMR samples from sequential cold and hot water leaches.

\begin{tabular}{|c|c|c|c|c|c|c|c|c|c|c|c|}
\hline \multirow[b]{2}{*}{ Sample } & \multirow[b]{2}{*}{ Sample ID } & \multirow[b]{2}{*}{ Leach } & \multicolumn{8}{|c|}{ Anion concentration in DMR bed media, wt $\%$, from water leaches } & \multirow{2}{*}{$\begin{array}{c}\text { Test } \\
\text { strip } \mathrm{pH}\end{array}$} \\
\hline & & & & Fluoride & Chloride & Nitrite & Sulfate & Bromide & Nitrate & Phosphate & \\
\hline 1 & DMR bed Jan 22015 from can & \multirow{5}{*}{$\begin{array}{l}\text { Cold } \\
\text { water }\end{array}$} & $<$ & $0.00016 \%$ & $0.0348 \%$ & $0.00059 \%$ & $1.86 \%$ & $0.00279 \%$ & $0.0112 \%$ & $0.0049 \%$ & 12 \\
\hline 2 & DMR bed Jan 132015 drums 3,5 & & $<$ & $0.00014 \%$ & $0.0561 \%$ & $<0.00010 \%$ & $2.66 \%$ & $0.00000 \%$ & $0.0013 \%$ & $0.0062 \%$ & 13 \\
\hline 3 & DMR bed Jan 132015 drum 6 & & $<$ & $0.00016 \%$ & $0.0570 \%$ & $<0.00011 \%$ & $2.77 \%$ & $0.00303 \%$ & $0.0019 \%$ & $0.0092 \%$ & 12 \\
\hline 4 & DMR wall scale Jan 132015 & & 1< & $0.00019 \%$ & $0.0560 \%$ & $0.00032 \%$ & $1.92 \%$ & $0.00205 \%$ & $0.0037 \%$ & $0.0059 \%$ & 12 \\
\hline 5 & DMR A/G scale 19 Jan 2015 & & & --- & --- & --- & --- & --- & --- & --- & $\cdots$ \\
\hline
\end{tabular}

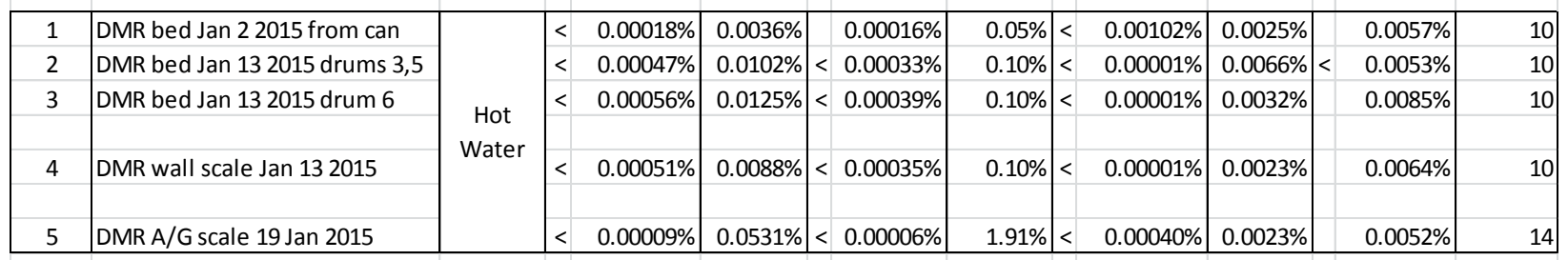

\begin{tabular}{|c|c|c|c|c|c|c|c|c|c|c|c|}
\hline 1 & DMR bed Jan 22015 from can & \multirow{5}{*}{$\begin{array}{c}\text { Total, } \\
\text { both } \\
\text { sequen- } \\
\text { tial } \\
\text { leaches }\end{array}$} & $<$ & $0.00034 \%$ & $0.0384 \%$ & $<$ & $0.00075 \%$ & $1.91 \%$ & $0.00381 \%$ & $0.0137 \%$ & $0.0106 \%$ \\
\hline 2 & DMR bed Jan 132015 drums 3,5 & & $<$ & $0.00061 \%$ & $0.0663 \%$ & 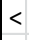 & $0.00043 \%$ & $2.76 \%$ & $0.00001 \%$ & $0.0079 \%$ & $0.0115 \%$ \\
\hline 3 & DMR bed Jan 132015 drum 6 & & $<$ & $0.00072 \%$ & $0.0695 \%$ & $<$ & $0.00051 \%$ & $2.87 \%$ & $0.00305 \%$ & $0.0051 \%$ & $0.0178 \%$ \\
\hline & Average DMR bed samples & & $<$ & $0.00056 \%$ & $0.0581 \%$ & $<$ & $0.00056 \%$ & $2.52 \%$ & $0.00229 \%$ & $0.0089 \%$ & $0.0133 \%$ \\
\hline 4 & DMR wall scale Jan 132015 & & $<$ & $0.00069 \%$ & $0.0648 \%$ & $<$ & $0.00067 \%$ & $2.02 \%$ & $0.00207 \%$ & $0.0060 \%$ & $0.0123 \%$ \\
\hline 5 & DMR A/G scale 19 Jan 2015 & & $<$ & $0.00009 \%$ & $0.0531 \%$ & & $0.00006 \%$ & $1.91 \%$ & $0.00040 \%$ & $0.0023 \%$ & $0.0052 \%$ \\
\hline
\end{tabular}

\begin{tabular}{|c|c|c|c|c|c|c|c|}
\hline Ratio, amount in wall scale/avg DMR bed samples & $-\cdots$ & 1.1 & 1.2 & 0.80 & 0.90 & 0.67 & 0.93 \\
\hline Ratio, amount in A-G/avg DMR bed samples & --- & 0.91 & 0.11 & 0.76 & 0.18 & 0.25 & 0.39 \\
\hline Notes: & & & & & & & \\
\hline 1. The Sample 5, DMR A/G scale, was received afte & wate & ach. & & & & & \\
\hline
\end{tabular}

[RDB-006-15 IWTU Ion Chromatography nrs16mar15.xIsx]reduced IC data \%

The anion analysis was repeated with a separate batch of aliquots for the DMR, wall scale, A/G scale, and other IWTU samples. These samples were leached in hot water for solubility analysis, anion analysis, and cation analysis. The anion analysis results are shown in Table 6-2. Like in the prior sequential dissolution analysis, concentrations of $\mathrm{F}, \mathrm{NO} 2$, and $\mathrm{Br}$ were low or non-detectable. Sulfate concentrations ranged between about 2-3 wt \% for the DMR and OGF samples, and 0.5-1.2 wt $\%$ for the OGF samples. Nitrate and $\mathrm{PO}_{4}$ levels were low, ranging around $0.04 \mathrm{wt} \%$ or less.

Carbonate samples ranged from 21-41 wt $\%$ in the DMR and PGF samples, and 1.7-3 wt $\%$ in the OGF samples. The presence of $\mathrm{CO}_{3}$ in the OGF samples, at levels up to $1,000 \mathrm{x}$ higher than the $\mathrm{CO}_{3}$ measured in the DMR bauxite sample $(0.0034 \mathrm{wt} \%)$, is potentially from petroleum coke ash, or from small amounts of carbonate product pass-through from the PGF. 
Table 6-2. Anion concentrations in the DMR samples from a single hot water leach.

\begin{tabular}{|c|c|c|c|c|c|c|c|c|c|}
\hline \multirow[b]{2}{*}{ Sample } & \multirow[b]{2}{*}{ ID } & \multicolumn{8}{|c|}{ Concentration, wt $\%$} \\
\hline & & Fluoride & Chloride & Nitrite & Sulfate & Bromide & Nitrate & Phosphate & Carbonate \\
\hline 18 & DMR $40 / 80$ bauxite $24 J \operatorname{lan} 15$ & $0.00011 \%$ & $0.0020 \%$ & $<0.000032 \%$ & $<0.01 \%$ & $<0.0000 \%$ & $<0.0006 \%$ & $<0.009 \%$ & $0.0034 \%$ \\
\hline 1 & DMR bed Jan 22015 from can & $<0.00014 \%$ & $0.0454 \%$ & $<0.000040 \%$ & $1.94 \%$ & $0.0047 \%$ & $0.0030 \%$ & $0.011 \%$ & $37.4 \%$ \\
\hline 2 & DMR bed Jan 132015 drums 3,5 & $<0.00014 \%$ & $0.0818 \%$ & $<0.000041 \%$ & $2.85 \%$ & $0.0019 \%$ & $<0.0008 \%$ & $0.012 \%$ & $21.2 \%$ \\
\hline \multirow[t]{3}{*}{3} & DMR bed Jan 132015 drum 6 & $<0.00012 \%$ & $0.0721 \%$ & $<0.000035 \%$ & $2.50 \%$ & $0.0000 \%$ & $0.0016 \%$ & $0.014 \%$ & $35.4 \%$ \\
\hline & DMR bed average & $<0.00013 \%$ & $0.0664 \%$ & $<0.000039 \%$ & $2.43 \%$ & $0.0022 \%$ & $0.0018 \%$ & $0.013 \%$ & $31.4 \%$ \\
\hline & DMR bed avg from EDS analysis & $\ldots$ & $0.00 \%$ & $\ldots$ & $2.61 \%$ & $0.00 \%$ & ... & $\ldots$ & $\ldots$ \\
\hline 4 & DMR wall scale Jan 132015 & $<0.00064 \%$ & $0.0639 \%$ & $<0.000188 \%$ & $2.37 \%$ & $0.0165 \%$ & $<0.0036 \%$ & $0.052 \%$ & $38.1 \%$ \\
\hline 4 & DMR wall scale Jan 132016 from EDS & ... & $0.00 \%$ & ... & $2.37 \%$ & ... & ... & ... & ... \\
\hline 5 & DMR A/G scale 19 Jan 2015 & $<0.00014 \%$ & $0.1030 \%$ & $<0.000041 \%$ & $2.15 \%$ & $0.0000 \%$ & $<0.0008 \%$ & $0.012 \%$ & $46.2 \%$ \\
\hline 5 & DMR A/G scale 19 Jan 2016 from EDS & ... & $0.15 \%$ & ... & $3.48 \%$ & $0.00 \%$ & ... & -.. & ... \\
\hline \multirow[t]{2}{*}{20} & PGF solids drum Feb. 22015 & $0.00010 \%$ & $0.1009 \%$ & $<0.000030 \%$ & $2.14 \%$ & $0.0043 \%$ & $0.0019 \%$ & $0.009 \%$ & $33.4 \%$ \\
\hline & PGF solids drum Feb. 22016 from EDS & $\ldots$ & $0.1100 \%$ & $\ldots$ & $2.73 \%$ & $\ldots$ & $\ldots$ & $\ldots$ &..- \\
\hline 13 & OGF drums 1-5 19jan15 & $0.01344 \%$ & $0.0366 \%$ & $<0.000085 \%$ & $1.21 \%$ & $0.0142 \%$ & $0.0422 \%$ & $0.049 \%$ & $3.0 \%$ \\
\hline 17 & OGF drums 21-24 19jan 15 & $0.00128 \%$ & $0.0174 \%$ & $<0.000092 \%$ & $0.51 \%$ & $0.0044 \%$ & $0.0196 \%$ & $0.032 \%$ & $1.7 \%$ \\
\hline \multirow[t]{3}{*}{19} & OGF solids 22 jan 15 & $0.00903 \%$ & $0.0283 \%$ & $<0.000047 \%$ & $0.82 \%$ & $0.0090 \%$ & $0.0305 \%$ & $0.044 \%$ & $2.4 \%$ \\
\hline & OGF average & $0.00792 \%$ & $0.0274 \%$ & $<0.000074 \%$ & $0.84 \%$ & $0.0092 \%$ & $0.0308 \%$ & $0.042 \%$ & $2.4 \%$ \\
\hline & OGF average from EDS & $\ldots$ & $0.00 \%$ & $\ldots$ & $0.48 \%$ & $\ldots$ & $\ldots$ & $\ldots$ & $\ldots$ \\
\hline \multicolumn{10}{|l|}{ Notes: } \\
\hline \multicolumn{10}{|c|}{ 1. These values are from a sample leach in hot DI water, and so only indicate amounts of these anions that are hot water-soluble. } \\
\hline \multicolumn{10}{|c|}{ 2. "<" indicates detection limit values for measurements be low the de tection limit. } \\
\hline \multicolumn{10}{|c|}{ 3. $\mathrm{F}, \mathrm{Cl}, \mathrm{NO} 2, \mathrm{SO} 4, \mathrm{Br}, \mathrm{NO} 3$, and $\mathrm{PO} 4$ we re de termined by ion chromatography. } \\
\hline \multicolumn{10}{|c|}{ 4. CO3 was determined by carbonate titration per ASTM D 3875-08 from RDB-013-15 IWTU metals12may15.xIsx. } \\
\hline \multicolumn{10}{|c|}{ 5. EDS elemental results are included where applicable, for comparison. } \\
\hline 6. Char & ge balance calculations: $\mathrm{F}-1 ; \mathrm{Cl}-1 ; \mathrm{NO} 2-1$ & $1 ; \mathrm{SO} 4-2 ; \mathrm{Br}-1 ; \mathrm{NC}$ & 03-1; PO4-3 & 3;CO3-3. & & & & & \\
\hline
\end{tabular}

[RDB-011-15 density, IC, grav, LOI 16mar15.xIsx]IC data hot le ach

Since the ion chromatograph used to obtain these analyses was configured for these analyses and concentrations, this analysis was unable to provide carbonate analysis. The $\mathrm{CO}_{3}$ analysis was obtained by ASTM-D 3875-08, "Standard Test Method for Alkalinity in Brackish Water, Seawater, and Brines." This method is used to measure carbonate and bicarbonate.

The $\mathrm{Cl}, \mathrm{SO}_{4}$, and $\mathrm{Br}$ analyses from the EDS analysis are included in the table for comparison. The $\mathrm{SO}_{4}$ value is normalized to $\mathrm{SO}_{4}$ from the EDS S measurement. While the EDS and wet chemistry analysis techniques are very different, these analyses generally agree within about $1-50 \%$.

\subsection{IWTU Cation Concentrations}

Cation analyses were done to determine both water-soluble and insoluble cations in the IWTU samples. Table 6-3 shows separate blocks for (a) insoluble metals determined by analyzing the remaining undissolved solids from the hot water solubility tests, after the LOI analyses, (b) the soluble cations determined by analyzing the dissolved solutions from the hot water solubility tests, and (c) the sum of the insoluble and soluble analysis results. 
Table 6-3. Cation concentrations in IWTU samples.

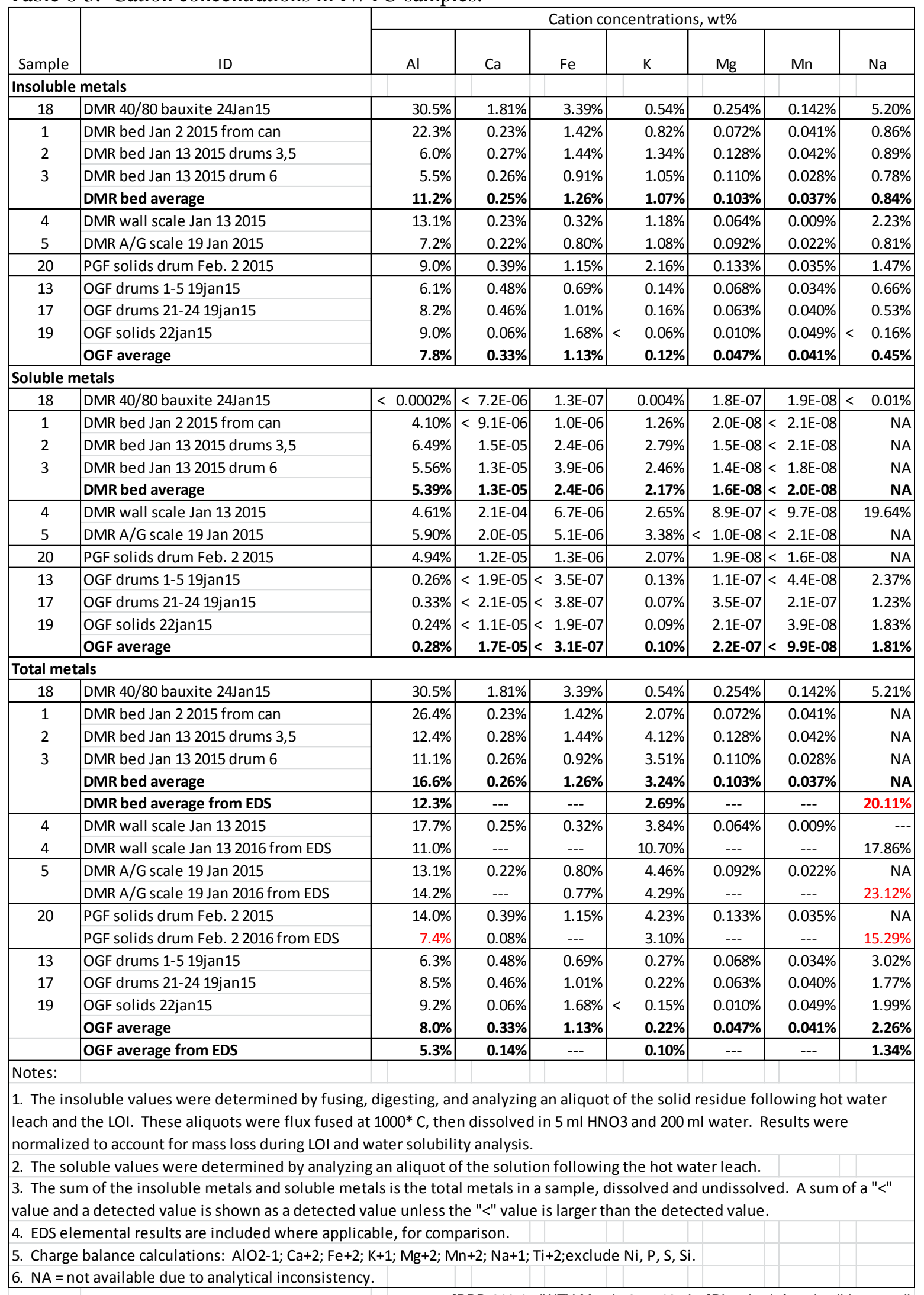

[RDB-013-15 IWTU Metals 8mar16.xlsx]Dissolved, fused solids normali 
Table 6-3. Cation concentrations in IWTU samples (continued).

\begin{tabular}{|c|c|c|c|c|c|c|c|}
\hline \multirow[b]{2}{*}{ Sample } & \multirow[b]{2}{*}{ ID } & \multicolumn{6}{|c|}{ Cation concentrations, wt $\%$} \\
\hline & & $\mathrm{Ni}$ & $\mathrm{P}$ & $\mathrm{S}$ & $\mathrm{Si}$ & $\mathrm{Ti}$ & $\begin{array}{l}\text { Total } \\
\text { Cations }\end{array}$ \\
\hline \multicolumn{8}{|c|}{ Insoluble metals } \\
\hline 18 & DMR $40 / 80$ bauxite $24 \operatorname{Jan} 15$ & $0.062 \%$ & $0.120 \%$ & $0.266 \%$ & $0.611 \%$ & $1.075 \%$ & $44.0 \%$ \\
\hline 1 & DMR bed Jan 22015 from can & $0.004 \%$ & $0.022 \%$ & $0.030 \%$ & $<0.110 \%$ & $0.257 \%$ & $26.2 \%$ \\
\hline 2 & DMR bed Jan 132015 drums 3,5 & $0.004 \%$ & $0.022 \%$ & $0.041 \%$ & $<0.050 \%$ & $0.059 \%$ & $10.2 \%$ \\
\hline \multirow[t]{2}{*}{3} & DMR bed Jan 132015 drum 6 & $0.004 \%$ & $0.017 \%$ & $0.026 \%$ & $<0.041 \%$ & $0.037 \%$ & $8.8 \%$ \\
\hline & DMR bed average & $0.004 \%$ & $0.020 \%$ & $0.032 \%$ & $<0.067 \%$ & $0.118 \%$ & $15.1 \%$ \\
\hline 4 & DMR wall scale Jan 132015 & $0.004 \%$ & $0.010 \%$ & $0.059 \%$ & $<0.135 \%$ & $0.021 \%$ & $17.3 \%$ \\
\hline 5 & DMR A/G scale 19 Jan 2015 & $0.003 \%$ & $0.005 \%$ & $0.246 \%$ & $<0.049 \%$ & $0.025 \%$ & $10.6 \%$ \\
\hline 20 & PGF solids drum Feb. 22015 & $0.008 \%$ & $0.026 \%$ & $0.053 \%$ & $<0.075 \%$ & $0.165 \%$ & $14.7 \%$ \\
\hline 13 & OGF drums 1-5 19jan15 & $0.017 \%$ & $0.032 \%$ & $0.075 \%$ & $<0.037 \%$ & $0.238 \%$ & $8.5 \%$ \\
\hline 17 & OGF drums 21-24 19jan15 & $0.017 \%$ & $0.031 \%$ & $0.062 \%$ & $<0.048 \%$ & $0.310 \%$ & $10.9 \%$ \\
\hline \multirow[t]{2}{*}{19} & OGF solids 22jan15 & $0.001 \%$ & $0.014 \%$ & $0.002 \%$ & $<0.040 \%$ & $0.348 \%$ & $11.4 \%$ \\
\hline & OGF average & $0.012 \%$ & $0.026 \%$ & $0.046 \%$ & $<0.042 \%$ & $0.299 \%$ & $10.3 \%$ \\
\hline \multicolumn{8}{|c|}{ Soluble metals } \\
\hline 18 & DMR $40 / 80$ bauxite $24 J a n 15$ & $<8.9 \mathrm{E}-08$ & $<0.00001 \%$ & $0.00007 \%$ & $2.3 \mathrm{E}-05$ & $<5.7 \mathrm{E}-08$ & $0.01 \%$ \\
\hline 1 & DMR bed Jan 22015 from can & $<1.1 \mathrm{E}-07$ & $0.024 \%$ & $0.57 \%$ & $3.9 \mathrm{E}-04$ & $1.2 \mathrm{E}-07$ & NA \\
\hline 2 & DMR bed Jan 132015 drums 3,5 & $2.2 \mathrm{E}-07$ & $0.032 \%$ & $1.00 \%$ & 7.7E-04 & $9.2 \mathrm{E}-08$ & NA \\
\hline \multirow[t]{2}{*}{3} & DMR bed Jan 132015 drum 6 & $1.6 \mathrm{E}-07$ & $0.028 \%$ & $0.89 \%$ & $6.9 \mathrm{E}-04$ & $1.3 \mathrm{E}-07$ & NA \\
\hline & DMR bed average & $1.7 \mathrm{E}-07$ & $0.028 \%$ & $0.822 \%$ & $6.2 \mathrm{E}-04$ & $1.1 \mathrm{E}-07$ & NA \\
\hline 4 & DMR wall scale Jan 132015 & $<5.3 \mathrm{E}-07$ & $0.028 \%$ & $0.64 \%$ & 2.7E-03 & $4.6 \mathrm{E}-07$ & $27.9 \%$ \\
\hline 5 & DMR A/G scale 19 Jan 2015 & $2.2 \mathrm{E}-07$ & $0.043 \%$ & $0.87 \%$ & $4.3 \mathrm{E}-04$ & $<7.3 \mathrm{E}-08$ & NA \\
\hline 20 & PGF solids drum Feb. 22015 & $1.6 \mathrm{E}-07$ & $0.040 \%$ & $0.87 \%$ & $5.6 \mathrm{E}-04$ & $1.6 \mathrm{E}-07$ & NA \\
\hline 13 & OGF drums 1-5 19jan15 & $<2.4 \mathrm{E}-07$ & $0.003 \%$ & $0.31 \%$ & $<4.4 \mathrm{E}-05$ & $<1.5 \mathrm{E}-07$ & $3.1 \%$ \\
\hline 17 & OGF drums 21-24 19jan15 & $<2.6 \mathrm{E}-07$ & $0.004 \%$ & $0.15 \%$ & 2.4E-04 & $<1.7 \mathrm{E}-07$ & $1.8 \%$ \\
\hline \multirow[t]{2}{*}{19} & OGF solids 22 jan 15 & $<1.3 \mathrm{E}-07$ & $0.003 \%$ & $0.25 \%$ & $4.2 \mathrm{E}-05$ & $<8.4 \mathrm{E}-08$ & $2.4 \%$ \\
\hline & OGF average & $<2.1 \mathrm{E}-07$ & $0.003 \%$ & $0.236 \%$ & $1.1 \mathrm{E}-04$ & $1.3 \mathrm{E}-07$ & $2.4 \%$ \\
\hline \multicolumn{8}{|c|}{ Total metals } \\
\hline 18 & DMR 40/80 bauxite 24Jan15 & $6.2 \mathrm{E}-04$ & $0.12041 \%$ & $0.27 \%$ & $0.614 \%$ & $1.07 \%$ & $44.0 \%$ \\
\hline 1 & DMR bed Jan 22015 from can & $4.5 \mathrm{E}-05$ & $0.046 \%$ & $0.60 \%$ & $0.149 \%$ & $0.26 \%$ & NA \\
\hline 2 & DMR bed Jan 132015 drums 3,5 & 4.4E-05 & $0.054 \%$ & $1.04 \%$ & $0.127 \%$ & $0.06 \%$ & NA \\
\hline \multirow[t]{3}{*}{3} & DMR bed Jan 132015 drum 6 & 4.1E-05 & $0.045 \%$ & $0.92 \%$ & $0.110 \%$ & $0.04 \%$ & NA \\
\hline & DMR bed average & 4.3E-05 & $0.049 \%$ & $0.85 \%$ & $0.129 \%$ & $0.12 \%$ & NA \\
\hline & DMR bed average from EDS & --- & --- & $0.87 \%$ & $1.960 \%$ & --- & --- \\
\hline 4 & DMR wall scale Jan 132015 & 3.7E-05 & $0.038 \%$ & $0.70 \%$ & $0.408 \%$ & $0.02 \%$ & $41.2 \%$ \\
\hline 4 & DMR wall scale Jan 132016 from EDS & --- & --- & $0.79 \%$ & $1.950 \%$ & --- & --- \\
\hline \multirow[t]{2}{*}{5} & DMR A/G scale 19 Jan 2015 & $3.3 \mathrm{E}-05$ & $0.048 \%$ & $1.12 \%$ & $0.092 \%$ & $0.02 \%$ & $20.0 \%$ \\
\hline & DMR A/G scale 19 Jan 2016 from EDS & --- & --- & $1.16 \%$ & $2.360 \%$ & --- & --- \\
\hline \multirow[t]{2}{*}{20} & PGF solids drum Feb. 22015 & $8.3 \mathrm{E}-05$ & $0.067 \%$ & $0.92 \%$ & $0.131 \%$ & $0.17 \%$ & $21.2 \%$ \\
\hline & PGF solids drum Feb. 22016 from EDS & --- & --- & $0.91 \%$ & $1.100 \%$ & $0.09 \%$ & --- \\
\hline 13 & OGF drums 1-5 19jan15 & $1.8 \mathrm{E}-04$ & $0.035 \%$ & $0.38 \%$ & $<0.042 \%$ & $0.24 \%$ & $11.6 \%$ \\
\hline 17 & OGF drums 21-24 19jan15 & 1.7E-04 & $0.035 \%$ & $0.22 \%$ & $0.072 \%$ & $0.31 \%$ & $12.8 \%$ \\
\hline \multirow[t]{3}{*}{19} & OGF solids 22 jan 15 & $1.2 \mathrm{E}-05$ & $0.018 \%$ & $0.25 \%$ & $0.044 \%$ & $0.35 \%$ & $13.8 \%$ \\
\hline & OGF average & $1.2 \mathrm{E}-04$ & $0.029 \%$ & $0.28 \%$ & $0.053 \%$ & $0.30 \%$ & $12.7 \%$ \\
\hline & OGF average from EDS & --- & --- & $0.16 \%$ & $0.410 \%$ & $0.19 \%$ & --- \\
\hline \multicolumn{8}{|l|}{ Notes: } \\
\hline \multicolumn{8}{|c|}{$\begin{array}{l}\text { 1. The insoluble values were determined by fusing, digesting, and analyzing an aliquot of the solid residue following hot } \\
\text { water leach and the LOI. These aliquots were flux fused at } 1000^{*} \mathrm{C} \text {, then dissolved in } 5 \mathrm{ml} \mathrm{HNO} \text { and } 200 \mathrm{ml} \text { water. Results } \\
\text { were normalized to account for mass loss during LOI and water solubility analysis. }\end{array}$} \\
\hline \multirow{2}{*}{\multicolumn{8}{|c|}{$\begin{array}{l}\text { 2. The soluble values were determined by analyzing an aliquot of the solution following the hot water leach. } \\
\text { 3. The sum of the insoluble metals and soluble metals is the total metals in a sample, dissolved and undissolved. A sum } \\
\text { of a "<" value and a detected value is shown as a detected value unless the " }<\text { "value is larger than the detected value. }\end{array}$}} \\
\hline & & & & & & & \\
\hline \multicolumn{8}{|c|}{ 4. EDS elemental results are included where applicable, for comparison. } \\
\hline \multicolumn{8}{|c|}{ 5. Charge balance calculations: $\mathrm{AlO} 2-1 ; \mathrm{Ca}+2 ; \mathrm{Fe}+2 ; \mathrm{K}+1 ; \mathrm{Mg}+2 ; \mathrm{Mn}+2 ; \mathrm{Na}+1 ; \mathrm{Ti}+2 ;$ exclude $\mathrm{Ni}, \mathrm{P}, \mathrm{S}, \mathrm{Si}$. } \\
\hline 6. $N A=n$ & t available due to analytical inconsistenc & & & & & & \\
\hline
\end{tabular}

[RDB-013-15 IWTU Metals 8mar16.xlsx]Dissolved, fused solids normali 


\section{LOSS-ON-IGNITION ANALYSES}

Loss-on-ignition (LOI) analyses were performed on selected samples, shown in Table 7-1. The LOI test is performed to indicate the amount of organic $\mathrm{C}, \mathrm{H}, \mathrm{N}, \mathrm{O}$, and $\mathrm{S}$ that would oxidize in a high temperature oxidizing lab oven. Three sets of LOI measurements were made. The first set was performed on aliquots of the as-received samples. For those samples with significant inorganic carbonate or other material that can be volatile or react at LOI temperatures, this set of LOI data could be somewhat biased high if there is mass loss in the LOI analysis that is not from organic material. Carbonate in the samples is one of the most likely inorganic species that could interfere with the LOI analysis. For this reason, two other sets of LOI measurements were made on aliquots of the same samples, after the hot water dissolution and drying. The UDS following the hot water dissolution test is presumably free of water-soluble species like $\mathrm{CO}_{3}$. These two sets of LOI data were obtained with the furnace at $650{ }^{\circ} \mathrm{C}$ and then raised to $750^{\circ} \mathrm{C}$.

None of the as-received samples analyzed had appreciable moisture, as expected. The DMR starting bauxite and the CRR bed media had low LOI results, all under $1 \mathrm{wt} \%$, as expected. The LOI results for the various DMR bed samples was somewhat scattered, ranging between 5.3-21.3 wt\%, presumably due to some variation in the representativeness of these samples. These results indicate that for the different DMR bed media samples, the coal content in these samples ranged from about 5-11 wt $\%$ (after accounting for the portion of the LOI in Sample 3 that could have been due to carbonate loss during the LOI test). The A/G scale sample had an LOI result of 5.4-5.7 wt\%, which was at the low end of the range of LOI results for the individual DMR bed samples. The PGF solids LOI was within the same range as the DMR bed sample LOI. The OGF solids LOI results ranged from about $73-80 \mathrm{wt} \%$, indicating that most of mass of the OGF solids was elutriated petroleum coke.

Figure 7-1 shows the individual sample and averaged LOI data for the as-received and post-hotwater-leach analyses. On average, loss of mass due to carbonate or other inorganic matter was negligible; the DMR bed average LOI results were essentially equivalent for the as-received and post-hot-waterleach analyses. In two out of three sets of samples (the DMR bed and OGF solid samples) the LOI actually decreased slightly when the LOI temperature was increased from $650^{\circ} \mathrm{C}$ to $750^{\circ} \mathrm{C}$, presumably due to oxidizing reactions of the residual inorganic matter, causing an increase in that mass. However, the PGF solids LOI mass increased when the LOI temperature was increased from $650{ }^{\circ} \mathrm{C}$ to $750^{\circ} \mathrm{C}$. 
Table 7-1. Loss-on-ignition analysis results.

\begin{tabular}{|c|c|c|c|c|c|}
\hline \multirow[b]{2}{*}{ Sample } & \multirow[b]{2}{*}{ ID } & \multicolumn{2}{|c|}{ As-received } & \multicolumn{2}{|c|}{$\begin{array}{l}\text { After hot water leach } \\
\text { and drying, } \\
\text { normalized to as- } \\
\text { received basis }\end{array}$} \\
\hline & & $\begin{array}{c}\text { Moisture, } \\
\text { wt } \%\end{array}$ & $\begin{array}{l}\text { LOI, wt\% } \\
\text { at } 750 \mathrm{C}\end{array}$ & $\begin{array}{r}\text { LOI, wt\% } \\
\text { at } 650 \mathrm{C} \\
\end{array}$ & $\begin{array}{c}\text { LOI, wt\% } \\
\text { at } 750 \mathrm{C}\end{array}$ \\
\hline 18 & DMR $40 / 80$ bauxite $24 \operatorname{Jan} 15$ & $-0.01 \%$ & $0.30 \%$ & $0.8 \%$ & $0.2 \%$ \\
\hline 1 & DMR bed Jan 22015 from can & --- & --- & $13.5 \%$ & $9.5 \%$ \\
\hline 2 & DMR bed Jan 132015 drums 3,5 & --- & --- & $15.7 \%$ & $13.7 \%$ \\
\hline 3 & DMR bed Jan 132015 drum 6 & $0.39 \%$ & $21.30 \%$ & $10.7 \%$ & $8.8 \%$ \\
\hline 10 & DMR bed media 22Jan 15 & $-0.14 \%$ & $5.30 \%$ & --- & --- \\
\hline--- & DMR bed media average & $0.12 \%$ & $13.30 \%$ & $13.3 \%$ & $10.6 \%$ \\
\hline 4 & DMR wall scale Jan 132015 & --- & --- & \multicolumn{2}{|c|}{ Insufficient sample } \\
\hline 5 & DMR A/G scale 19 Jan 2015 & --- & --- & $5.7 \%$ & $5.4 \%$ \\
\hline 20 & PGF solids drum Feb. 22015 & --- & --- & $13.7 \%$ & $17.4 \%$ \\
\hline 11 & CRR bed media Jan. 18, 2015 & $-0.04 \%$ & $0.10 \%$ & --- & $-\cdots$ \\
\hline 12 & CRR bed media Jan. 22, 2015 & $0.01 \%$ & $0.70 \%$ & --- & --- \\
\hline--- & CRR bed media average & $-0.02 \%$ & $0.40 \%$ & --- & --- \\
\hline 13 & OGF drums 1-5 19jan15 & $0.66 \%$ & $77.90 \%$ & $80.4 \%$ & $79.6 \%$ \\
\hline 15 & OGF drums 11-15 19jan15 & $0.19 \%$ & $76.80 \%$ & --- & --- \\
\hline 17 & OGF drums 21-24 19jan15 & $0.12 \%$ & $78.00 \%$ & $73.8 \%$ & $72.8 \%$ \\
\hline 19 & OGF solids 22 jan 15 & $0.04 \%$ & $76.60 \%$ & $74.7 \%$ & $73.4 \%$ \\
\hline--- & OGF solids average & $0.25 \%$ & $77.30 \%$ & $76.3 \%$ & $75.3 \%$ \\
\hline
\end{tabular}

Notes:

1. Some moisture measurements were slightly negative due possibly to experimental error. 2. All of Sample 3 was used due its small initial mass, to ensure that the coal:product ratio remained representative.

3. Residual solids exhibited slight weight gain after furnace temperature was increased from $650 \mathrm{C}$ to $750 \mathrm{C}$, perhaps due to more complete oxidation of ash components.

[RDB-011-15 density, IC, grav, LOI 20mar15.xIsx]LOIs

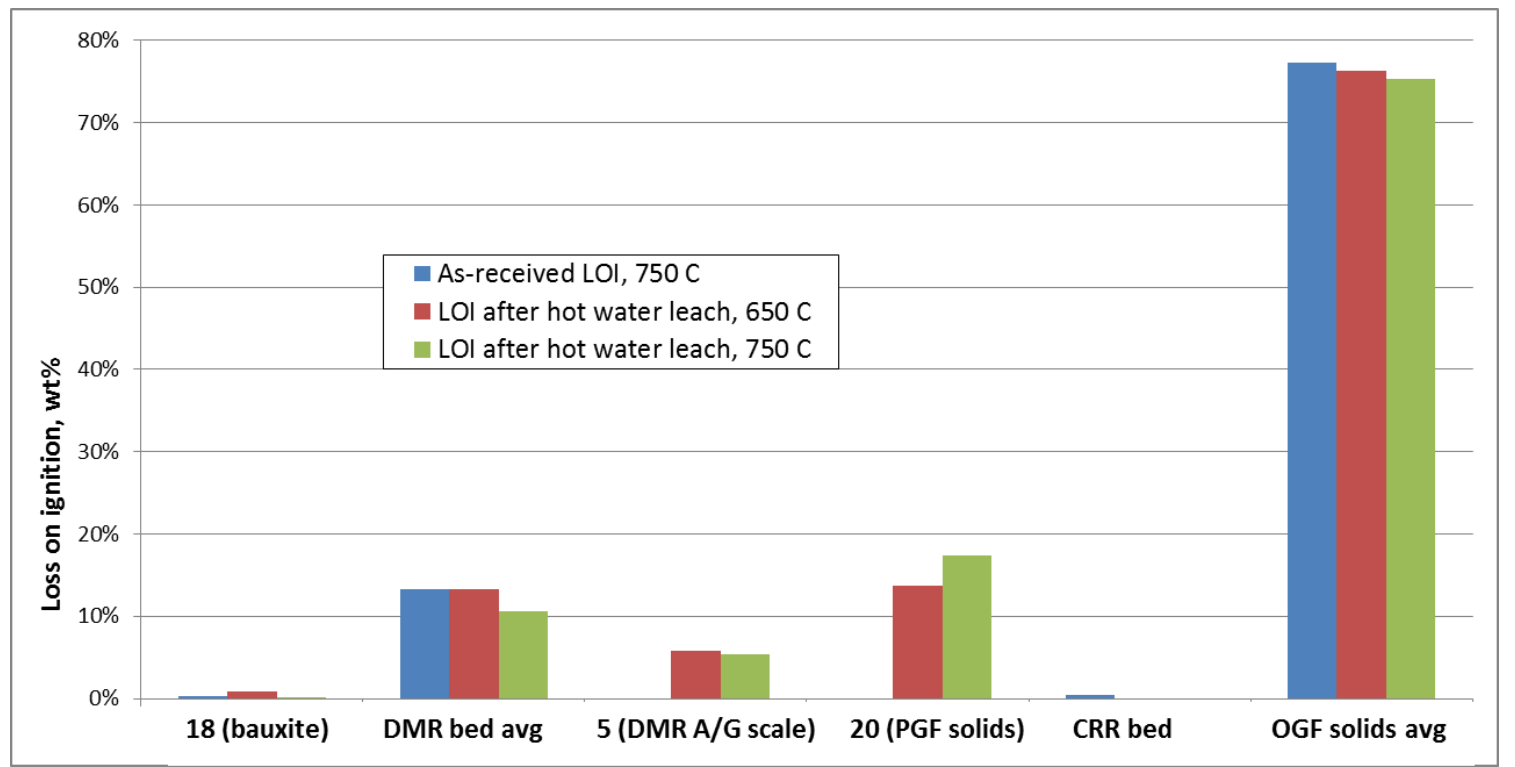

Figure 7-1. Individual and averaged LOI results. 


\section{DMR SAMPLE MINERALOGY}

X-ray diffraction (XRD) analyses were done on selected DMR bed, wall scale, and auger scale samples. Crystalline mineral species detected in the DMR bed samples are shown in Figures 8-1 through 8-3. Minerals detected in these samples include corundum, sodium aluminum silicates, coal carbon (identified as graphite), kalsilite, two forms of sodium carbonates (possibly natrite and gregoryite), sodium aluminum silicate, and potassium aluminum oxides. XRD analyses continue; these results are preliminary. Amorphous species are not detected by XRD. Any amorphous species in the samples that are not crystalline will not appear, so the XRD results are not necessarily indicative of the entire mass of the samples.

The XRD analysis for the DMR wall scale is shown in Figure 8-4. The relative amounts of detected minerals are shown in Figure 8-5. The wall scale appears to have generally the same minerals detected in the DMR bed samples, with added calcite.

Results of the XRD analysis of the A/G scale are shown in Figure 8-6. The relative amounts of detected minerals are shown in Table 8-7. The A/G scale appears to have generally the same minerals detected in the DMR bed samples, with added calcite. 


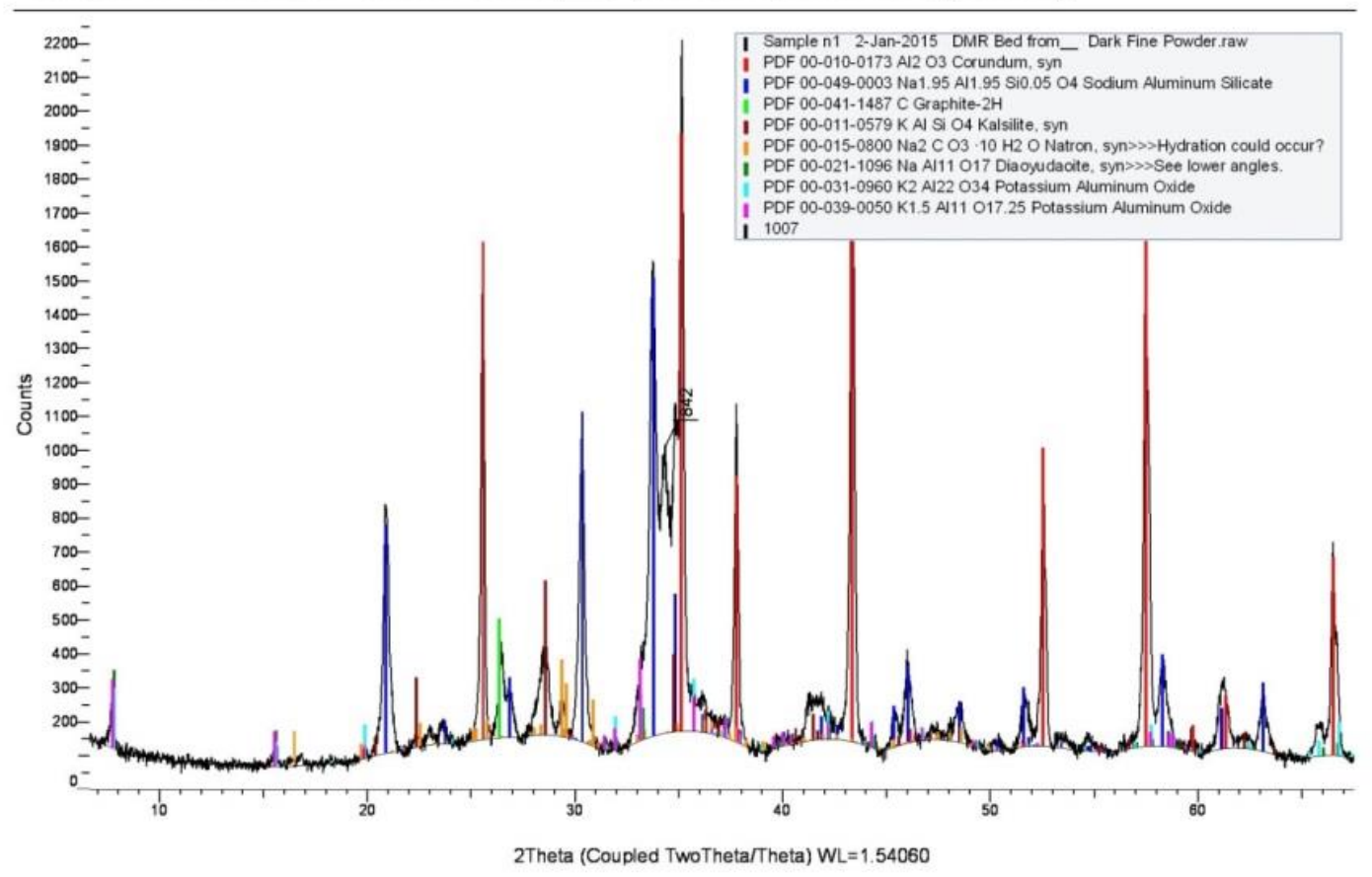

Pattern List for INL Sample \#1 2-Jan-2015 DMR Bed from Can

\begin{tabular}{|c|c|c|c|c|c|}
\hline Color & Index & Compound Name & Formula & S-Q & Name \\
\hline$\square$ & 0 & \begin{tabular}{|l|l|} 
a $-\mathrm{A} 12 \mathrm{O}$ & Aluminum Oxide \\
\end{tabular} & $\mathrm{A} 2 \mathrm{O} 3$ & $61.65 \%$ & PDF 01-076-8056 \\
\hline E & 1 & Kalsīite & $\mathrm{KN}(\mathrm{Si}$ O4) & $6.07 \%$ & PDF 01.087.1707 \\
\hline$\square$ & 2 & $\begin{array}{l}\text { Sodium Aluminum Silicon } \\
\text { Oxide }\end{array}$ & Na1.95 ( Al1.95 Si0.05 O4) & $31.30 \%$ & PDF 01-070-4845 \\
\hline$\square$ & 3 & Graphite-2H & C & $0.99 \%$ & PDF 01-075-1621 \\
\hline
\end{tabular}

Figure 8-1. XRD scan of the January 2, 2015 DMR bed product sample. S-Q in the pattern list indicates semi-quantitative analysis of the crystalline species. 


\section{Sample \#2 13-Jan-2015 DMR Bed \#3 \#5 Drum sv'd 850um}

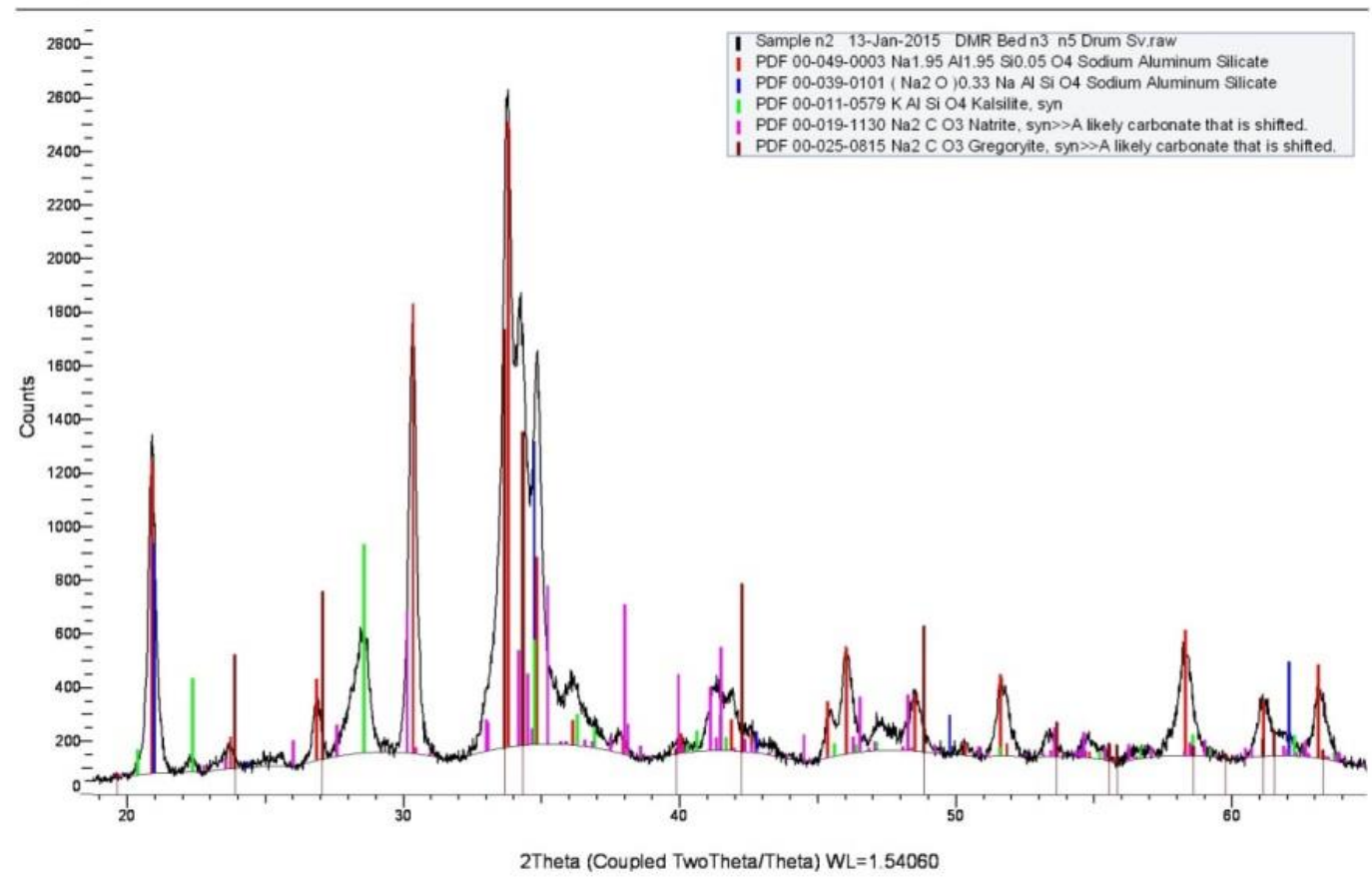

\section{Pattern List INL Sample \#2 13-Jan-2015 Bed \#3 Drum \#5}

\begin{tabular}{|c|c|c|c|c|c|c|c|}
\hline Color & Index & & mpound Nam & & Formula & S-Q & Name \\
\hline$\square$ & 0 & \begin{tabular}{|l} 
Sodium \\
Oxide
\end{tabular} & Aluminum & Silicon & Na1.95 ( A1.95 Si0.05 O4) & $91.34 \%$ & PDF 01-070-4845 \\
\hline 口 & 1 & Kalsilite & & & $\mathrm{KAN}(\mathrm{Si} \mathrm{O} 4)$ & $8.66 \%$ & PDF 01-087-1707 \\
\hline
\end{tabular}

Figure 8-2. XRD scan of the DMR bed sample from drums 3 and 5 collected January 13, 2015. 
Sample \#3 13-Jan-2015 DMR Bed \#6 Drum \#6 (Fine Powder Sv 850 um)

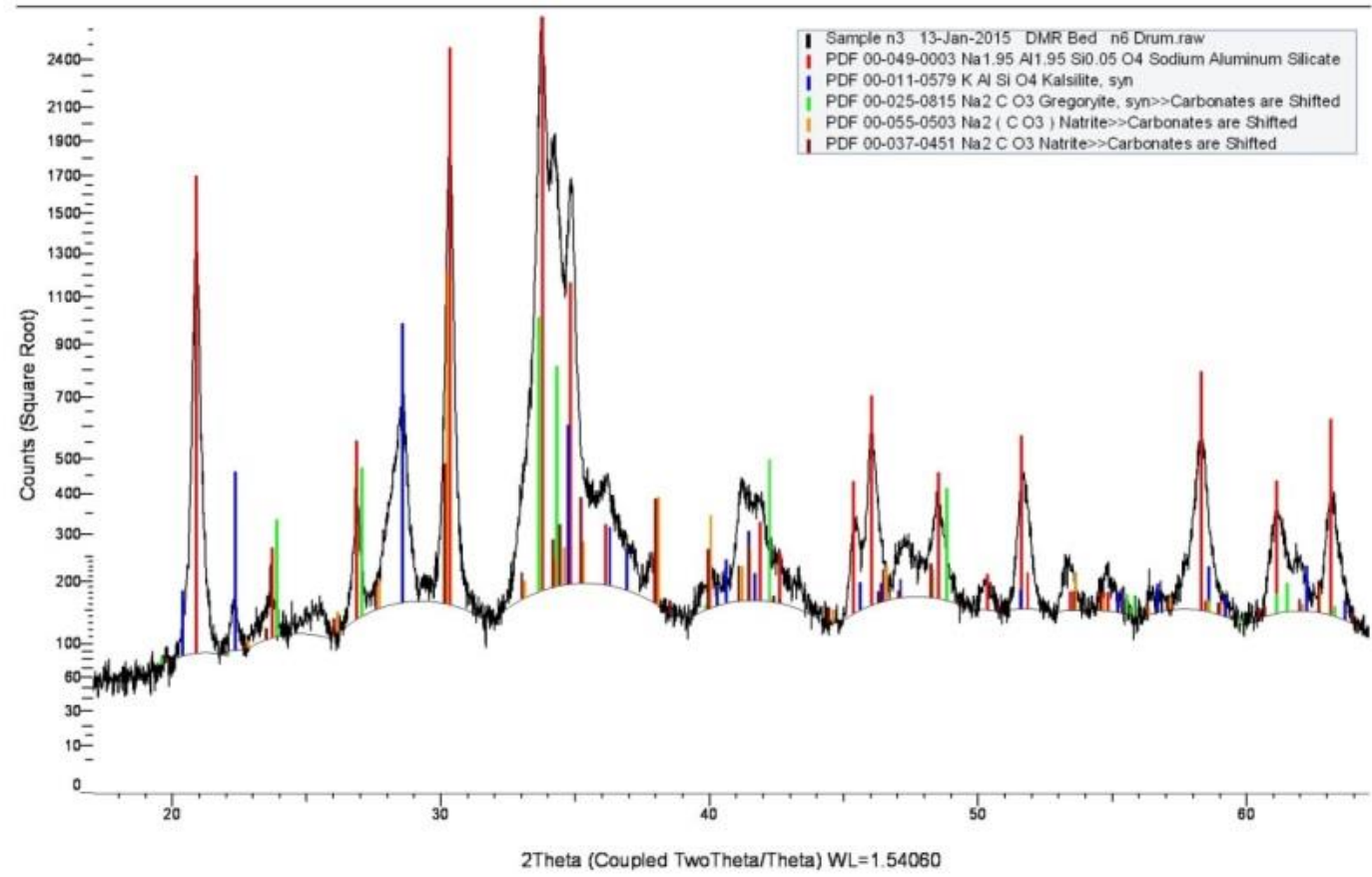

\section{Pattern List INL Sample \#3 13-Jan-2015 DMR Bed \#6 Drum}

\begin{tabular}{|c|l|c|l|l|c|}
\hline Color & Index & Name & \multicolumn{1}{|c|}{ Compound Name } & \multicolumn{1}{|c|}{ Formula } & S-Q \\
\hline$\square$ & 0 & PDF 01-070-4845 & $\begin{array}{l}\text { Sodium Aluminum Silicon } \\
\text { Oxide }\end{array}$ & Na1.95 ( A1 1.95 Si0.05 O4) & $85.83 \%$ \\
\hline$\square$ & 1 & PDF 01-087-1707 & Kalsilite & KAN ( Si O4) & $14.17 \%$ \\
\hline
\end{tabular}

Figure 8-3. XRD scan of the DMR bed sample from drum 6 collected January 13, 2015. 
INL Sample \#4 DMR Wall Scale (Bark) 13-Jan-2015

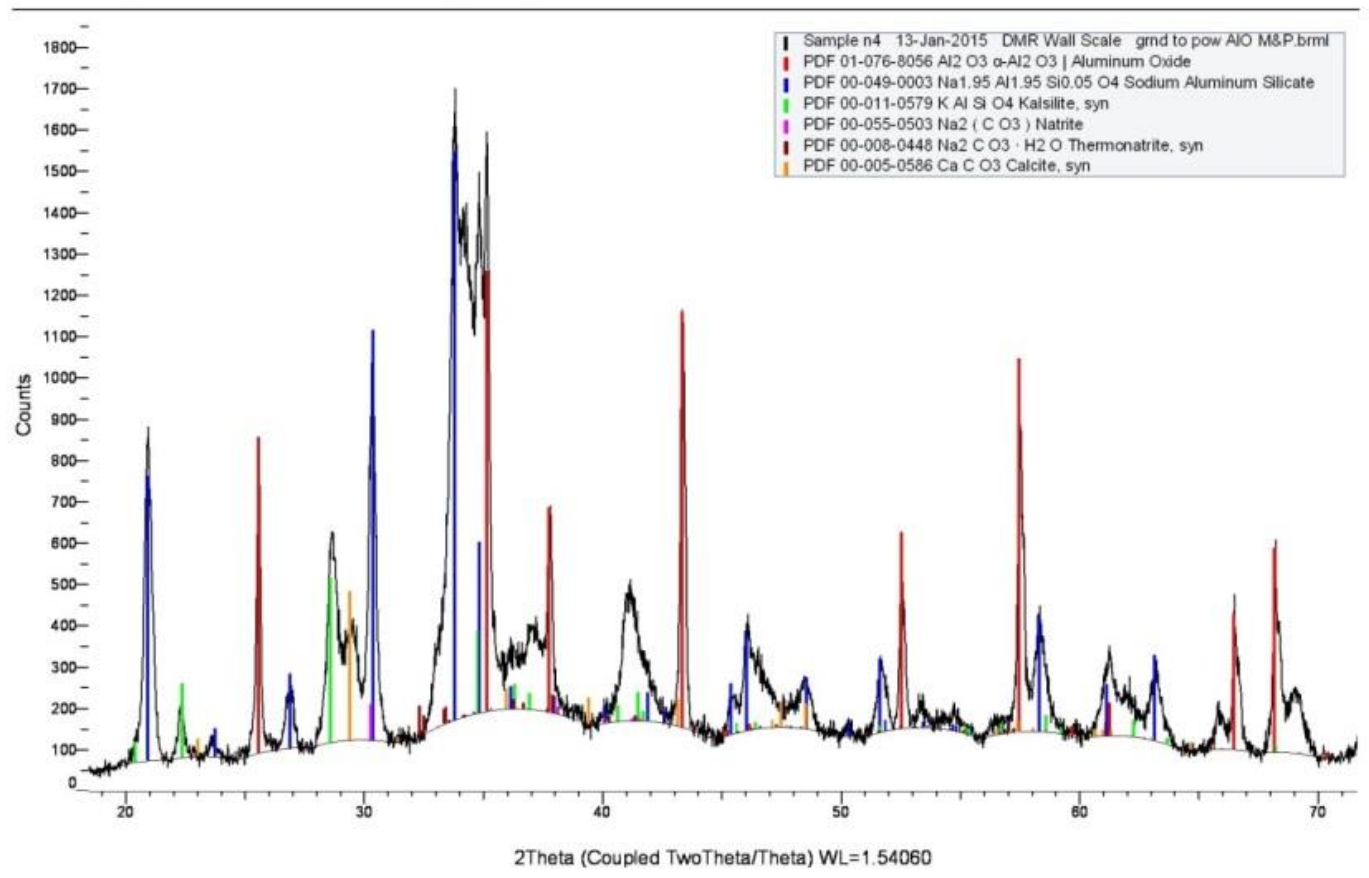

\section{Pattern List for INL Sample \#4 DMR Wall Scale (Bark) 13-Jan-2015}

\begin{tabular}{|c|c|c|c|c|c|}
\hline Coler & Index & Name & Compound Name & Formula & s-o \\
\hline$\square$ & 0 & PDF 01.076-8056 & $\begin{array}{llll}\text { a-A2 } & 03 & \text { I } & \text { Aluminum } \\
\text { Oxide }\end{array}$ & N2OS & $35.37 \%$ \\
\hline 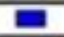 & 1 & PDF 00-049-0003 & Sodium Numinum Silcate & Nat.95 N1.95 510.05 O4 & $4207 \%$ \\
\hline$\square$ & 2 & PDF 00.011 .0579 & Kalsilite, syn & KA SIO4 & $1215 \%$ \\
\hline$\square$ & 3 & PDF 00-055.0503 & Netrice & $\operatorname{Na2}(\mathrm{C} \mathrm{O})$ & $261 \times$ \\
\hline E & 4 & PDF $00-000-0448$ & Thermenatrite. syn & $\mathrm{Na} 2 \mathrm{CO}$ O3. $\mathrm{H} 2 \mathrm{O}$ & $230 \%$ \\
\hline$\square$ & 5 & PDF 00.005 .0585 & Calche, syn & $\mathrm{CaCO}$ & $5.51 \%$ \\
\hline
\end{tabular}

Figure 8-4. XRD scan of the DMR wall scale sample collected January 13, 2015. 
DMR Scale from A-G 19-Jan-2015

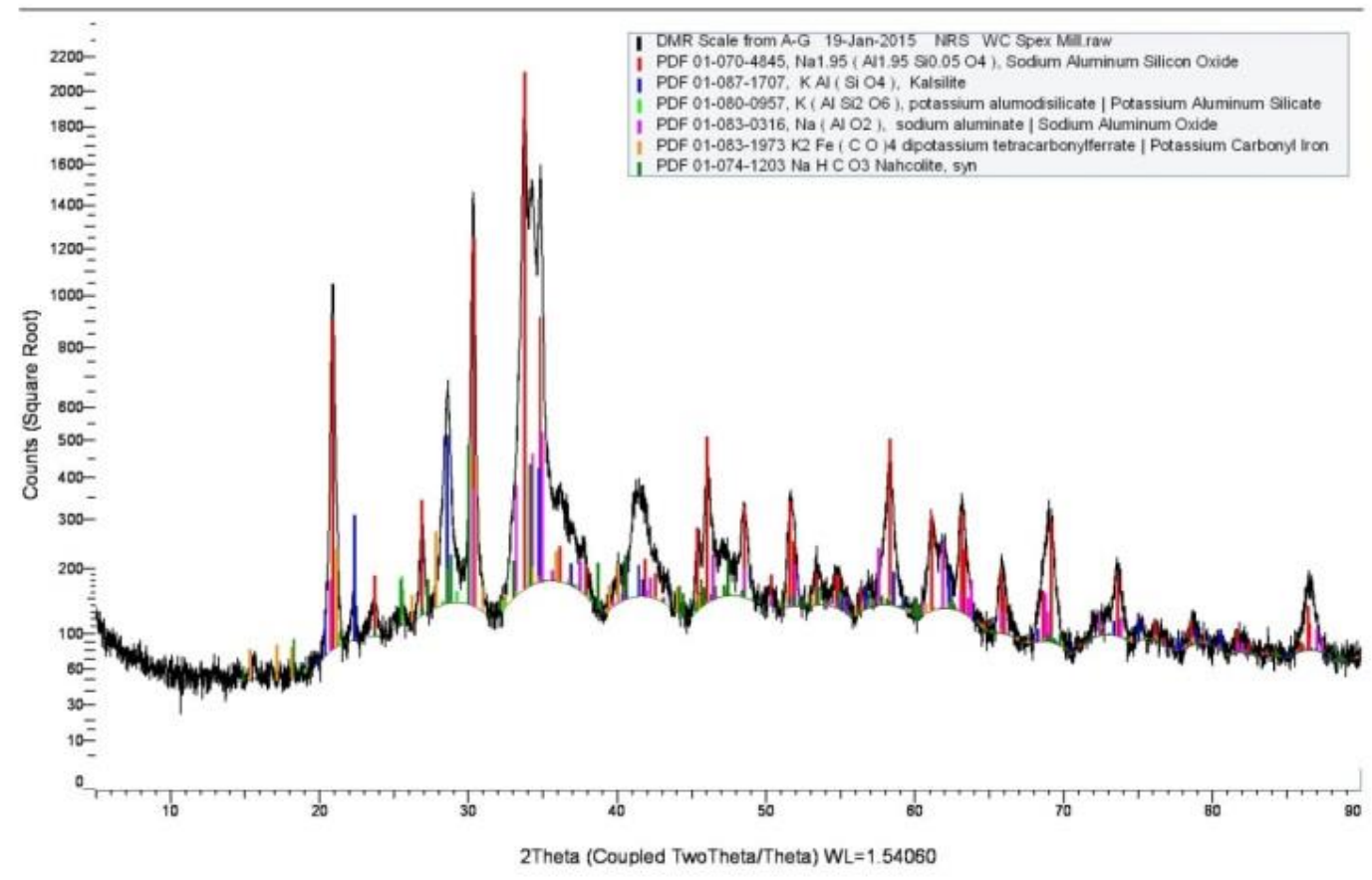

\section{DMR Scale from A/G 19-Jan-2015 Pattern/Phase List}

\begin{tabular}{|c|c|c|c|c|c|}
\hline Index & Coler & Cempound Name & Fermula & S-Q & Name \\
\hline 0 & $\square$ & Sodium Aluminum Slicon Oxide & Na1.95 (A1.95 Sio.05 O4) & $55.32 \%$ & POF 01-070-4345 \\
\hline 1 & $\square$ & Nahcolite, syn & $\mathrm{NaHCO}$ & $18.10 \%$ & PDF 01-074-1203 \\
\hline 2 & $\square$ & \begin{tabular}{|l|l|} 
potassium alumodislicate I Potassium Aluminum \\
Sllicate
\end{tabular} & $K($ A S:2 O6) & $1.20 \%$ & POF 01-080-0957 \\
\hline 3 & $\square$ & sodium aluminate I Sodium Aluminum Oxide & $\mathrm{Na}(\mathbf{A} \mathrm{O} 2)$ & $13.44 \%$ & POF 01-083-0316 \\
\hline 4 & $\square$ & $\begin{array}{l}\text { dipotassium tetracarbonyterrate I Potassium Carbonyl } \\
\text { Iren }\end{array}$ & $\mathrm{K} 2 \mathrm{~F}_{*}(\mathrm{C} O)^{4}$ & $5.33 \%$ & POF 01-083-1973 \\
\hline 5 & E & Kalsillte & KA ( SI O4) & $6.61 \%$ & POF 01-087-1707 \\
\hline
\end{tabular}

Figure 8-5. XRD scan of the DMR A/G scale sample collected January 19, 2015. 


\section{PGF SOLIDS SEM/EDS ANALYSES}

Samples of PGF solids removed from the PGF vessel were collected for analysis. The PGF solids consist mainly of particles ranging in size from under 10 micron to over 50 micron, as shown in Figures 9-1 through 9-3. Very few particles exceeded 50 micron, and practically no particles exceeded 100 micron in size.

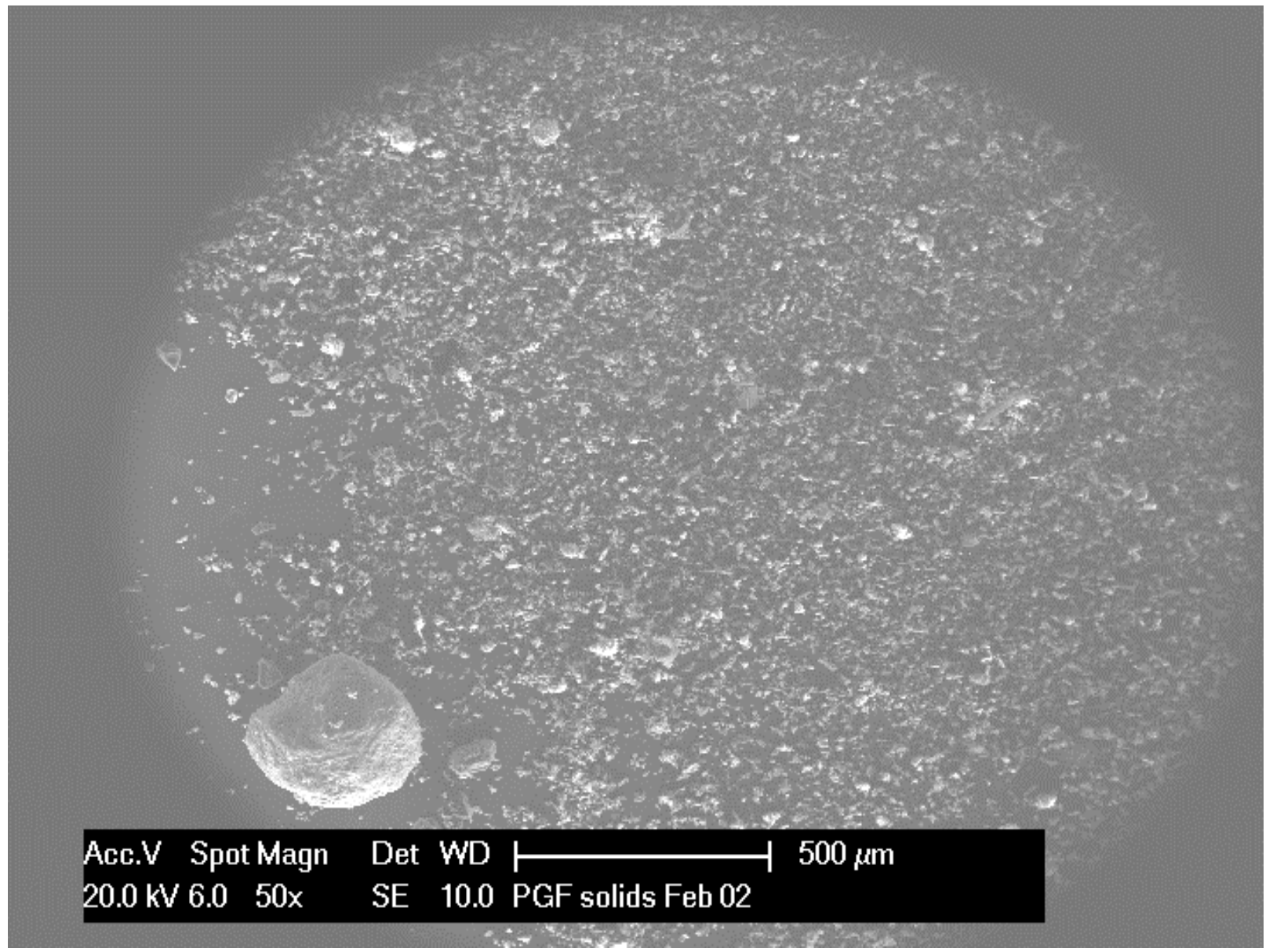

Figure 9-1. SEM photograph of PGF solids removed after shutdown (sampled on February 2, 2015), at 50x magnification. 


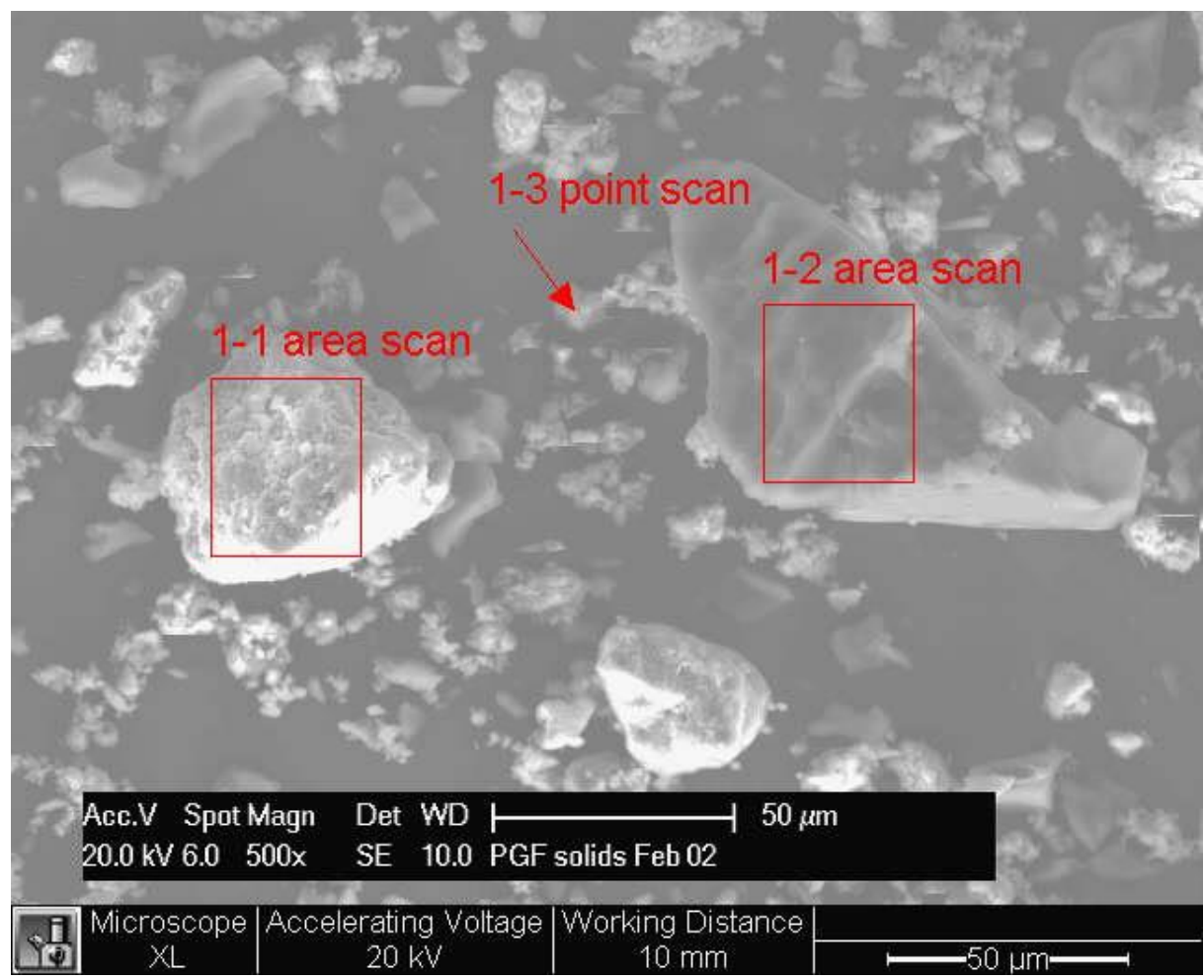

Figure 9-2. SEM photograph of PGF solids removed after shutdown (sampled on February 2, 2015), at 500x magnification, showing particles $>50$ micron.

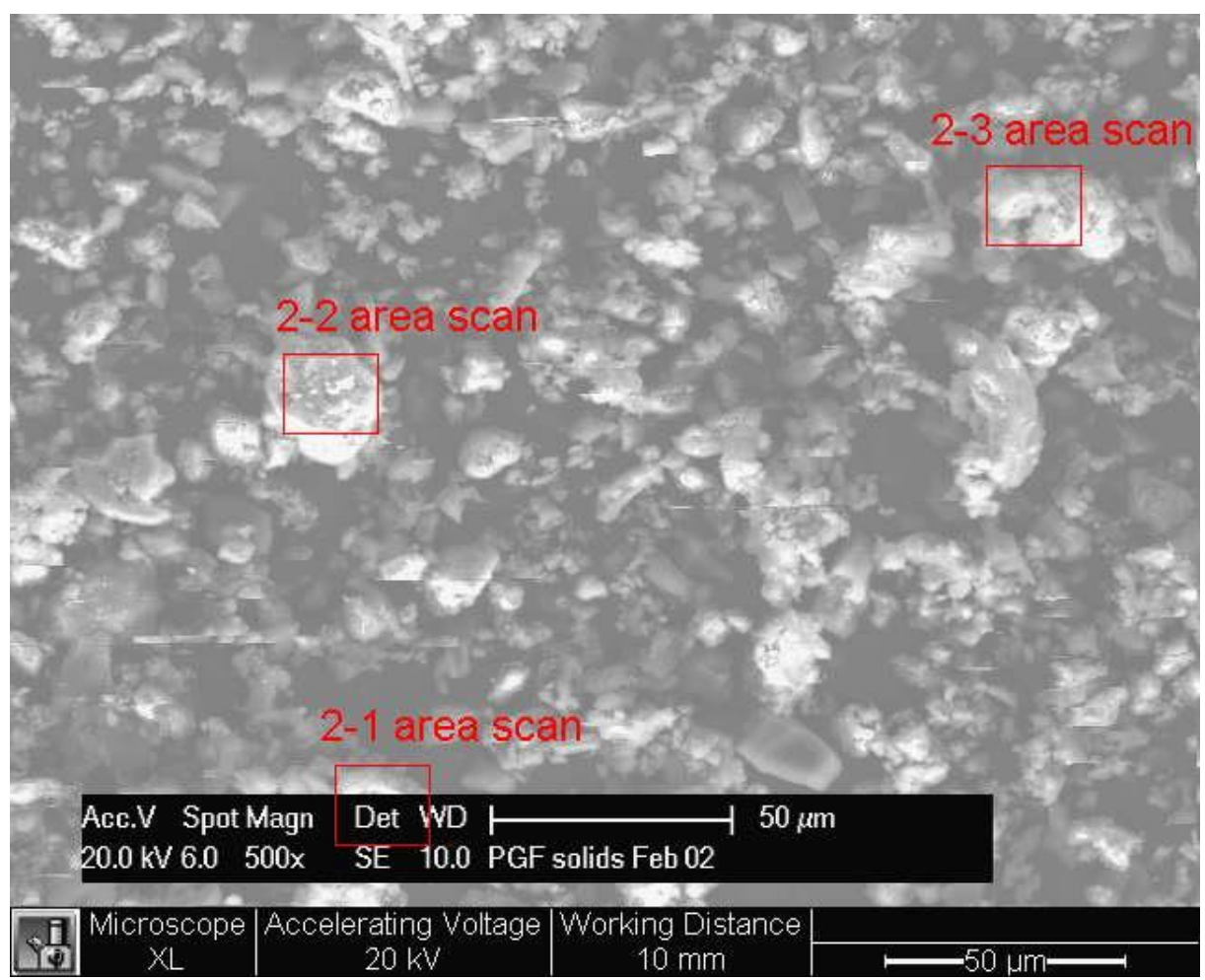

Figure 9-3. SEM photograph of PGF solids removed after shutdown (sampled on February 2, 2015), at 500x magnification, showing majority of particles $<50$ micron. 
The SEM photos show that the shapes of the product particles in the PGF particle were different from those in the DMR bed samples. While the DMR bed product particles were largely spherical and uniform, the product particles in the PGF solids were less spherical, and there was a greater amount of $<20$ micron particles.

The elemental compositions from EDS for the PGF solids are shown in Table 9-1. The elemental composition for individual particles varied. Elutriated coal particles (Particle 1-2 in Figure 9-2 and in Table 9-1) are mostly carbon. Some particles (Particle 1-3) appear to have both coal and $\mathrm{Na}, \mathrm{Al}, \mathrm{Si}, \mathrm{K}$, carbonates and oxides, with lesser levels of coal ash elements ( $\mathrm{Si}, \mathrm{Ca}, \mathrm{Ti}$, and $\mathrm{Fe}$ ). Many particles appear to consist of primarily $\mathrm{Na}, \mathrm{Al}, \mathrm{Si}$, and $\mathrm{K}$ carbonates and oxides. The average composition of the PGF solids based on the SEM/EDS analysis was about $40 \mathrm{w} \% \mathrm{C}$ (presumably from $\mathrm{CO}_{3}$ and coal $\mathrm{C}$ ), $30 \mathrm{wt} \%$ oxygen (presumably from $\mathrm{CO}_{3}$ and oxides), $15 \mathrm{wt} \% \mathrm{Na}$ and $3 \mathrm{wt} \% \mathrm{~K}$ (presumably from $\mathrm{Na}$, $\mathrm{K}$ carbonate, aluminate, and aluminosilicate), about $1 \mathrm{wt} \%$ each Si and S, and less than $1 \mathrm{wt} \%$ of several other elements. These average values should be considered semi-qualitative and semi-quantitative.

Table 9-1. Elemental analysis from SEM/EDS for the PGF solids Feb. 2, 2015.

\begin{tabular}{|c|c|c|c|c|c|c|c|}
\hline \multirow[b]{2}{*}{ Element } & \multicolumn{7}{|c|}{ Composition, wt\% } \\
\hline & \begin{tabular}{|c} 
Area \\
scan 1- \\
1
\end{tabular} & $\begin{array}{c}\text { Area } \\
\text { scan 1-2 } \\
\text { (coal) }\end{array}$ & Point 1-3 & $\begin{array}{c}\text { Area scan } \\
2-1\end{array}$ & $\begin{array}{c}\text { Areascan } \\
2-2\end{array}$ & $\begin{array}{c}\text { Area scan } \\
2-3\end{array}$ & $\begin{array}{c}\text { Averages } \\
\text { of area } \\
\text { scans }\end{array}$ \\
\hline C & 29.44 & 89.01 & 47.31 & 28.53 & 17.9 & 33.01 & 40.87 \\
\hline 0 & 35.74 & 9.84 & 31.46 & 36.16 & 40.31 & 29.26 & 30.46 \\
\hline $\mathrm{Na}$ & 21.75 & 0.40 & 7.57 & 18.35 & 28.03 & 15.62 & 15.29 \\
\hline Al & 7.93 & 0.24 & 9.24 & 11.32 & 7.89 & 8.02 & 7.44 \\
\hline $\mathrm{Si}$ & 0.68 & 0.15 & 1.80 & 1.22 & 0.90 & 1.84 & 1.10 \\
\hline $\mathrm{S}$ & 1.21 & 0.24 & 0.31 & 0.76 & 1.41 & 1.53 & 0.91 \\
\hline $\mathrm{Cl}$ & 0.08 & 0.02 & 0.04 & 0.13 & 0.04 & 0.34 & 0.11 \\
\hline K & 2.94 & 0.04 & 1.62 & 2.52 & 3.05 & 8.44 & 3.10 \\
\hline $\mathrm{Ca}$ & 0 & 0 & 0.25 & 0.21 & 0.11 & 0.52 & 0.08 \\
\hline $\mathrm{Ti}$ & 0 & 0 & 0.26 & 0.09 & 0.09 & 0.29 & 0.09 \\
\hline $\mathrm{Fe}$ & 0.23 & 0.05 & 0.16 & 0.73 & 0.27 & 1.14 & 0.43 \\
\hline \multirow[t]{2}{*}{ Total } & 100.00 & 99.99 & 100.02 & 100.02 & 100.00 & 100.01 & 99.87 \\
\hline & & & \multicolumn{5}{|c|}{ [dmr sample psd, eds analysis 9feb15.xIsx]EDS PGF solids } \\
\hline
\end{tabular}

The PGF solids collected after completion of TI-102 were different from the PGF solids collected and analyzed in October 2014 (Soelberg, 2014) because the post T-102 solids contain significant amounts of carbonate and aluminate product fines from the simulated waste feed. The PGF solids from October 2014 were mostly elutriated coal particles, with a few attrited bauxite particles, since those samples were collected prior to starting simulated waste feed. 


\section{CRR BED MEDIA SEM/EDS ANALYSES}

Two samples of CRR bed media were collected for sample analysis after TI-102 - Part 2 shutdown.

Figures 10-1 and 10-2 show two different SEM views at a low magnification (50x). The bauxite particles are mostly spherical and of different size because of attrition or other size reduction such as thermal cracking. The particles also have surface irregularities that might be the result of particle impacts. The particles are generally large enough to fill the SEM view at even low magnifications. Particles ranging in size from about $200 \mu \mathrm{m}$ to about $1,200 \mu \mathrm{m}$ were visible.

The red squares in the SEM photos show the areas of EDS scans. The elemental compositions from these scans are shown in Table 10-1. As shown in the table, the primary composition of the CRR bed media is alumina, with some silica, iron oxide, titanium oxide, and potassium oxide. The EDS scans can cover a portion of the particle surface, but the depth of the EDS scan only penetrates a short distance, on the order of 1-5 $\mu \mathrm{m}$, into the surface.

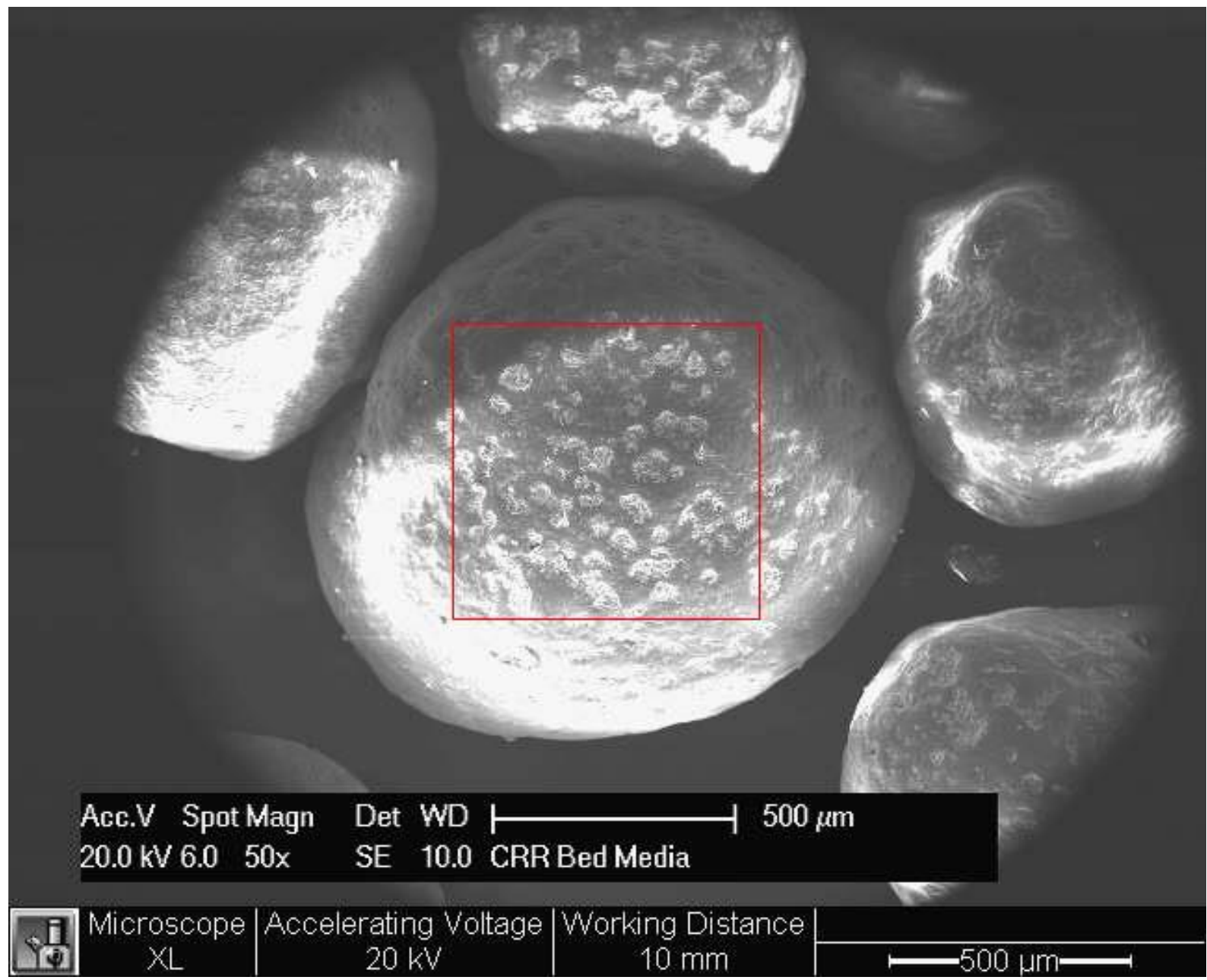

Figure 10-1. SEM photo of CRR bed media. 


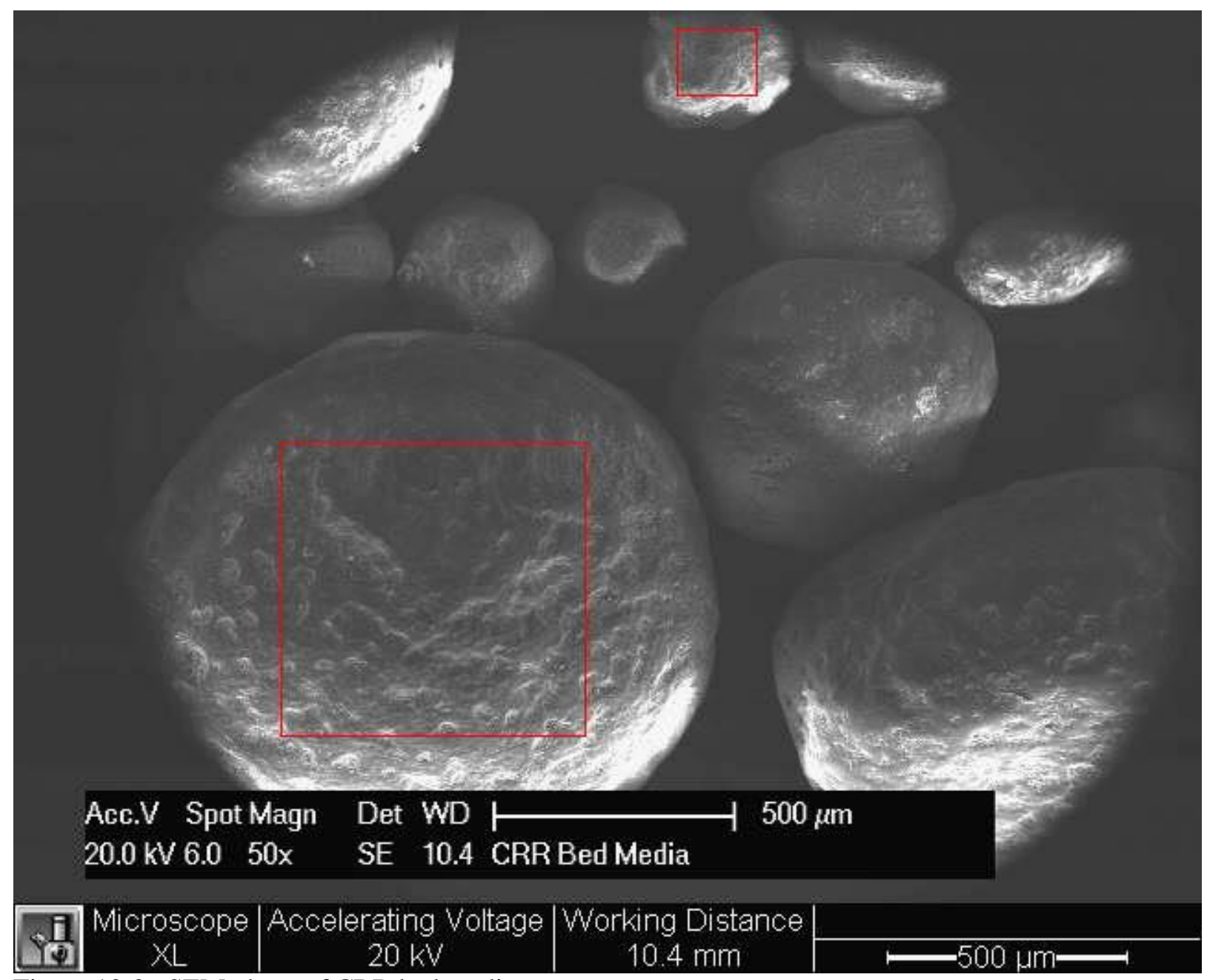

Figure 10-2. SEM photo of CRR bed media.

Table 10-1. Elemental analysis from SEM/EDS for the CRR bed media Jan. 18, 2015, Sample 11.

\begin{tabular}{|c|r|r|r|r|}
\hline & \multicolumn{4}{|c|}{ Composition, wt\% } \\
\cline { 2 - 6 } Element & $\begin{array}{c}\text { Area scan } \\
\text { large } \\
\text { particle }\end{array}$ & $\begin{array}{c}\text { Area scan } \\
\text { lower left } \\
\text { particle }\end{array}$ & $\begin{array}{c}\text { Area scan } \\
\text { small center } \\
\text { particle }\end{array}$ & $\begin{array}{c}\text { Averages } \\
\text { of area } \\
\text { scans }\end{array}$ \\
\hline $\mathrm{O}$ & 40.33 & 40.78 & 41.66 & $\mathbf{4 0 . 9 2}$ \\
$\mathrm{Na}$ & 0.34 & 0.25 & 0.23 & $\mathbf{0 . 2 7}$ \\
$\mathrm{Al}$ & 41.76 & 40.81 & 38.40 & $\mathbf{4 0 . 3 2}$ \\
\hline $\mathrm{Si}$ & 6.47 & 7.84 & 5.55 & $\mathbf{6 . 6 2}$ \\
\hline $\mathrm{P}$ & 0.20 & 0.06 & 0.15 & $\mathbf{0 . 1 4}$ \\
\hline $\mathrm{K}$ & 1.29 & 1.60 & 0.12 & $\mathbf{1 . 0 0}$ \\
\hline $\mathrm{Ca}$ & 0.66 & 0.75 & 0.21 & $\mathbf{0 . 5 4}$ \\
\hline $\mathrm{Ti}$ & 2.44 & 2.26 & 2.51 & $\mathbf{2 . 4 0}$ \\
$\mathrm{V}$ & 0.95 & 1.01 & 0.03 & $\mathbf{0 . 6 6}$ \\
\hline $\mathrm{Cr}$ & 0.70 & 0.58 & 0.09 & $\mathbf{0 . 4 6}$ \\
\hline $\mathrm{Fe}$ & 4.86 & 4.06 & 11.05 & $\mathbf{6 . 6 6}$ \\
\hline $\mathrm{Total}$ & 100.00 & 100.00 & 100.00 & 100.00 \\
\hline
\end{tabular}




\section{OGF SOLIDS SAMPLE ANALYSES}

Results of the October 2014 OGF sample analyses showed that nearly all of the OGF solids at that time was-were attrited coke particles (Soelberg 2015). The amount of bauxite attrition during the time represented by those samples was very small compared to the amount of coke elutriated from the CRR.

OGF samples were also collected for analysis on November 20, 2014, following the time period when high elutriation rates of bauxite from the CRR were observed, based on the amounts of bauxite that were added to the CRR to maintain the CRR bed level. See Appendix A for a summary of those analyses. Table 11-1 shows that the OGF solids sampled at that time were about $39 \mathrm{wt} \%$ combined bauxite and coke ash, and about 48-51 wt\% carbon from elutriated coke particles. This analysis indicates that for the time period represented by this sample, the elutriated bauxite was a little more than $1 / 3$ of the total mass attrited from the CRR. The remainder of the elutriated solids from the CRR was coke and coke ash.

Table 11-1. OGF Nov. 20, 2014 sample proximate and ultimate analysis.

\begin{tabular}{|c|c|c|c|c|c|c|c|c|c|c|c|}
\hline & \multicolumn{11}{|c|}{ Weight $\%$ AD (as determined) } \\
\hline Sample Name & $\begin{array}{l}\text { Mois- } \\
\text { ture }\end{array}$ & $\begin{array}{l}\text { Vola- } \\
\text { tile }\end{array}$ & $\begin{array}{l}\text { Bauxite } \\
\text { and ash }\end{array}$ & $\begin{array}{c}\text { Fixed } \\
\text { C }\end{array}$ & $\begin{array}{c}\text { Total } \\
\text { proximate } \\
\text { analysis } \\
\text { (moisture, } \\
\text { Vol, bauxite } \\
\text { + ash, and } \\
\text { Fixed C) }\end{array}$ & $\mathrm{H}$ & C & $\mathrm{N}$ & $\begin{array}{c}\text { O (by } \\
\text { difference) }\end{array}$ & S & $\begin{array}{c}\text { Total } \\
\text { ultimate } \\
\text { analysis } \\
\text { (moisture, } \\
\text { bauxite + } \\
\text { ash, C, H, N, } \\
\text { O, and S) }\end{array}$ \\
\hline OGF Nov. 202014 sample & 0.36 & 9.28 & 39.34 & 51.02 & 100.00 & 0.17 & 48.40 & 1.16 & 10.30 & 0.27 & 100.00 \\
\hline
\end{tabular}

OGF samples were collected for analysis in January 2015 following TI-102. LOI measurements on these samples shown in Section 6 show that about $77 \mathrm{wt} \%$ of the off-gas solids remaining the OGF after shutdown was elutriated coke. The other $23 \%$ was a combination of coke ash, bauxite, and a small amount $(0.25 \mathrm{wt} \%)$ moisture.

Figures 11-1 through 11-3 show the OGF solids in SEM micrographs. The samples appear similar to those OGF samples collected and analyzed in October 2014 (Soelberg 2014). Nearly all of the particles range in size from less than $1 \mu \mathrm{m}$ to $100 \mu \mathrm{m}$. 


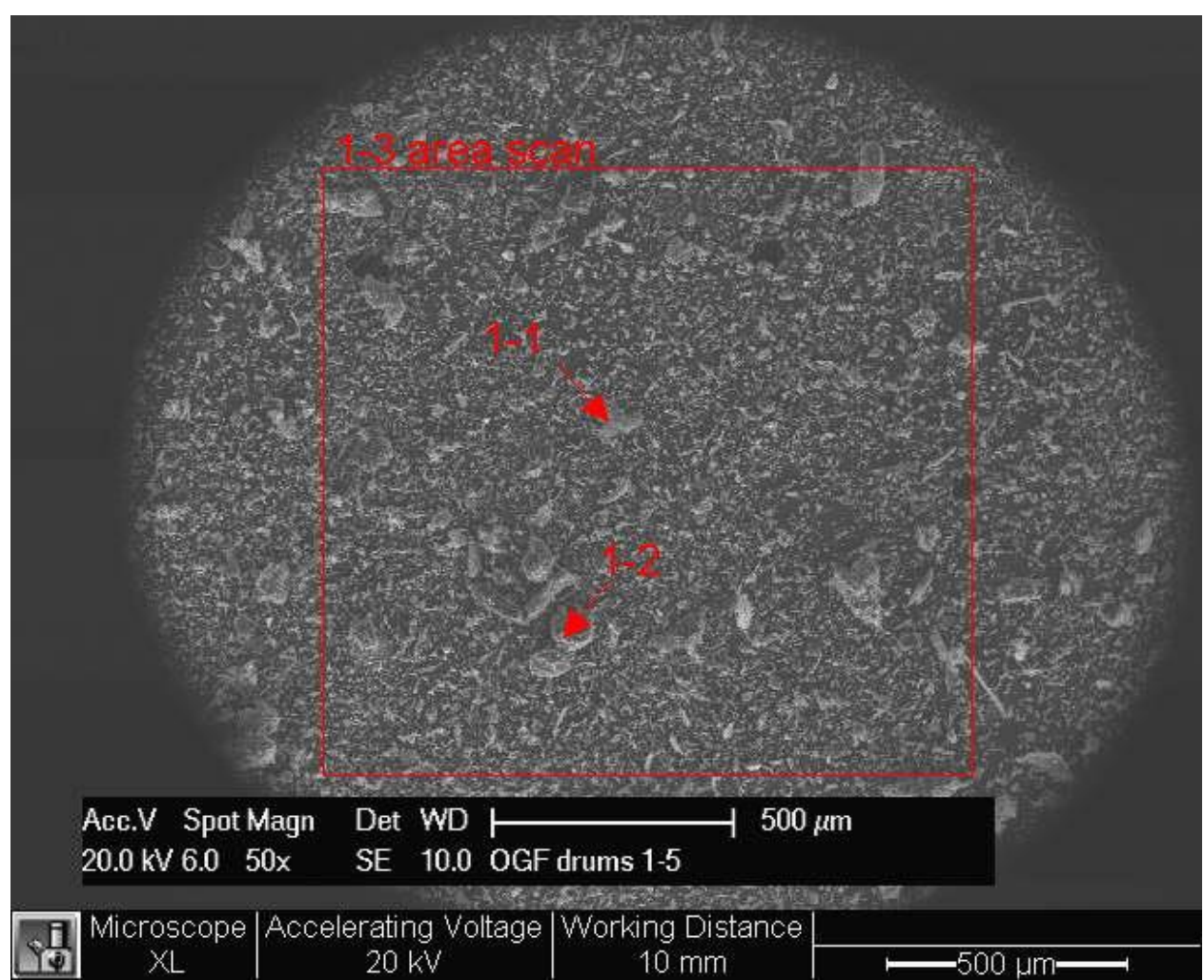

Figure 11-1. SEM photograph of OGF solids from Drums 1 through 5 at 50x magnification.

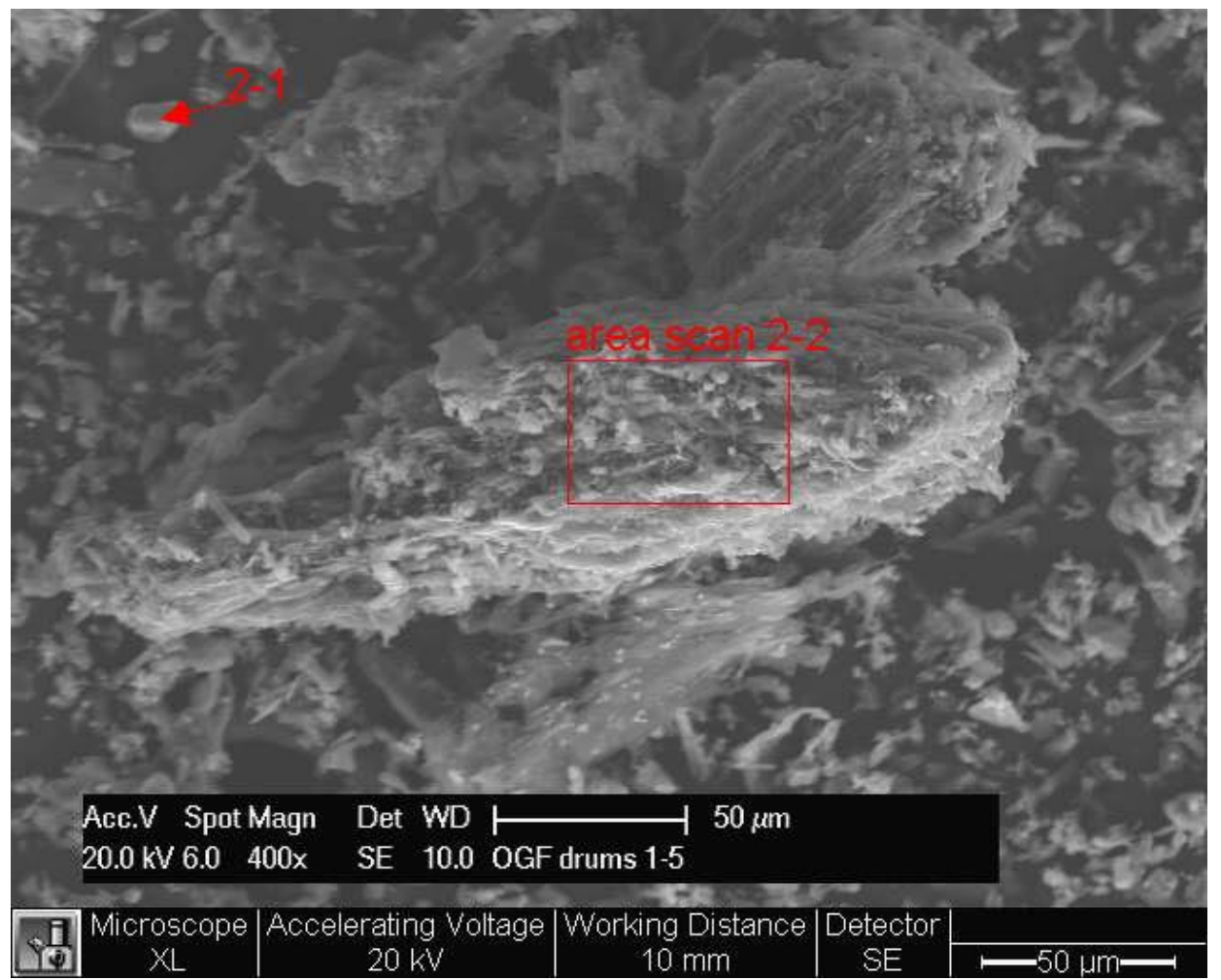

Figure 11-2. SEM photograph of OGF solids from Drums 1 through 5 at 400x magnification. 


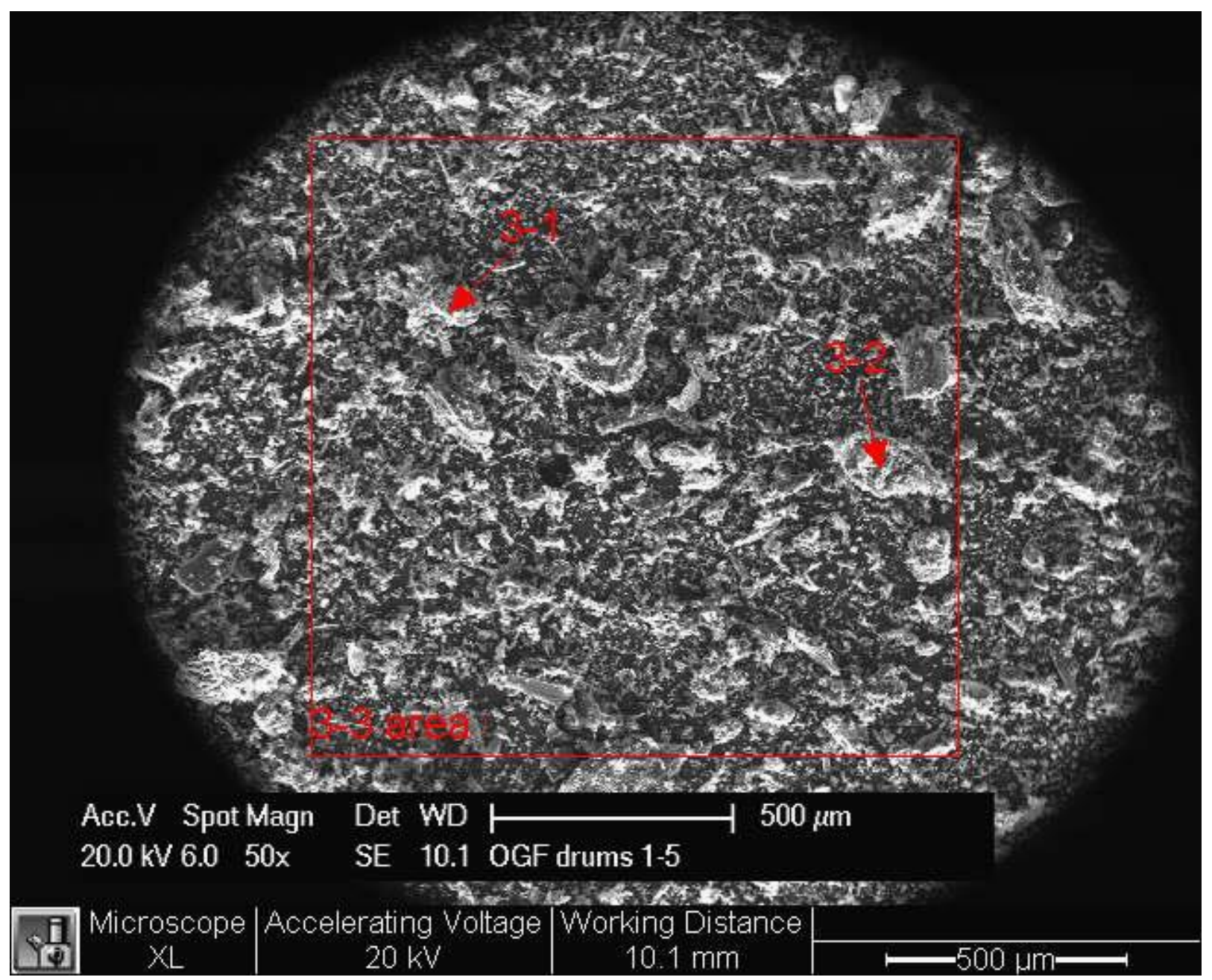

Figure 11-3. SEM photograph of OGF filter solids from Drums 21 through 24 at 50x magnification.

Tables 11-2 through 11-4 show the elemental compositions estimated by SEM/EDS of three OGF solids samples. The area scans in these tables are indicated by the red boxes in the SEM photos (see Figures 11-1 through 11-3 for two of the three samples). The point scans of individual particles are indicated by the red arrows in the photos. The average results for each of the three sample analyses are shown in Figure 11-4.

The averaged results for all three OGF solids samples are shown in Table 11-5. These analyses show that about $79 \mathrm{wt} \%$ of the OGF solids is coke fines, co-mingled with attrited bauxite particles. The inorganic components include oxides or other forms of $\mathrm{Al}$ and smaller amounts of $\mathrm{Na}, \mathrm{Si}, \mathrm{S}, \mathrm{K}, \mathrm{Ca}$, and Ti. The average ratio of Al:Na in the CRR bed media analyses was about 150:1. The average ratio of $\mathrm{Al}: \mathrm{Na}$ in the OGF solids analyses was about 3.9. As a result, the Na in the OGF solids appears to be enriched compared to Al. This degree of enrichment in the OGF solids did not occur for K. The Al:K ratio in the CRR bed media of 40 , and the $\mathrm{Al} ; \mathrm{K}$ ratio in the OGF solids averaged 53. 
Table 11-2. Elemental analysis from SEM/EDS for the OGF solids drums 1-5 19 Jan. 19, 2015 (Sample 13).

\begin{tabular}{|c|r|r|r|r|r|r|}
\hline & \multicolumn{7}{|c|}{ Composition, wt\% } \\
\cline { 2 - 8 } Element & $\begin{array}{c}\text { Area scan } \\
\text { large } \\
\text { particle }\end{array}$ & $\begin{array}{c}\text { Area } \\
\text { scan 1-3 }\end{array}$ & $\begin{array}{c}\text { Area } \\
\text { scan 2-2 }\end{array}$ & $\begin{array}{c}\text { Area } \\
\text { scan 2-3 }\end{array}$ & $\begin{array}{l}\text { Bauxite } \\
\text { particle }\end{array}$ & $\begin{array}{c}\text { Averages } \\
\text { of area } \\
\text { scans }\end{array}$ \\
\hline $\mathrm{C}$ & 92.80 & 82.70 & 86.65 & 88.09 & 27.92 & $\mathbf{7 5 . 6 3}$ \\
$\mathrm{O}$ & 5.92 & 14.06 & 10.86 & 11.10 & 38.44 & $\mathbf{1 6 . 0 8}$ \\
$\mathrm{Na}$ & 0.75 & 1.24 & 1.00 & 0.20 & 4.66 & $\mathbf{1 . 5 7}$ \\
\hline $\mathrm{Al}$ & 0.28 & 1.26 & 0.94 & 0.21 & 28.83 & $\mathbf{6 . 3 0}$ \\
\hline $\mathrm{Si}$ & 0.12 & 0.36 & 0.25 & 0.19 & 0.10 & $\mathbf{0 . 2 0}$ \\
$\mathrm{S}$ & 0.11 & 0.21 & 0.16 & 0.14 & 0.03 & $\mathbf{0 . 1 3}$ \\
$\mathrm{K}$ & 0.00 & 0.00 & 0.00 & 0.00 & 0.00 & $\mathbf{0 . 0 0}$ \\
\hline $\mathrm{Ca}$ & 0.01 & 0.16 & 0.14 & 0.07 & 0.02 & $\mathbf{0 . 0 8}$ \\
\hline $\mathrm{Ti}$ & 0.00 & 0.00 & 0.00 & 0.00 & 0.00 & $\mathbf{0 . 0 0}$ \\
\hline Total & 99.99 & 99.99 & 100.00 & 100.00 & 100.00 & $\mathbf{1 0 0 . 0 0}$ \\
\hline
\end{tabular}

Table 11-3. Elemental analysis from SEM/EDS for the OGF solids drums 21-24 19 Jan. 19, 2015 (Sample 17).

\begin{tabular}{|c|r|r|r|r|r|}
\hline \multirow{2}{*}{ Element } & \multicolumn{6}{|c|}{ Composition, wt\% } \\
\cline { 2 - 7 } & $\begin{array}{c}\text { Area scan 3- } \\
\text { 1 Bauxite } \\
\text { particle }\end{array}$ & $\begin{array}{c}\text { Area scan } \\
\text { Area scan }\end{array}$ & $\begin{array}{c}\text { Area scan } \\
\text { Averages } \\
\text { of area } \\
\text { scans }\end{array}$ \\
\hline $\mathrm{C}$ & 53.55 & 90.19 & 83.77 & \multicolumn{1}{c|}{83.87} & $\mathbf{7 7 . 8 5}$ \\
\hline $\mathrm{O}$ & 14.18 & 6.72 & 12.92 & 11.39 & $\mathbf{1 1 . 3 0}$ \\
$\mathrm{Na}$ & 0.64 & 1.26 & 1.16 & 1.45 & $\mathbf{1 . 1 3}$ \\
\hline $\mathrm{Al}$ & 27.70 & 1.04 & 1.38 & 1.82 & $\mathbf{7 . 9 9}$ \\
\hline $\mathrm{Si}$ & 1.39 & 0.32 & 0.37 & 0.52 & $\mathbf{0 . 6 5}$ \\
\hline $\mathrm{S}$ & 0.12 & 0.23 & 0.13 & 0.25 & $\mathbf{0 . 1 8}$ \\
\hline $\mathrm{K}$ & 0.38 & 0.11 & 0.09 & 0.19 & $\mathbf{0 . 1 9}$ \\
\hline $\mathrm{Ca}$ & 0.24 & 0.08 & 0.15 & 0.35 & $\mathbf{0 . 2 1}$ \\
\hline $\mathrm{Ti}$ & 1.78 & 0.03 & 0.05 & 0.15 & $\mathbf{0 . 5 0}$ \\
\hline Total & 99.98 & 99.98 & 100.02 & 99.99 & $\mathbf{9 9 . 9 9}$ \\
\hline
\end{tabular}

Table 11-4. Elemental analysis from SEM/EDS for OGF solids collected on Jan. 22, 2015 (Sample 19).

\begin{tabular}{|c|c|c|c|c|c|}
\hline \multirow[b]{3}{*}{ Element } & \multicolumn{5}{|c|}{ Composition, wt\% } \\
\hline & Area scan & Area scan & Area scan & Area scan & $\begin{array}{c}\text { Averages } \\
\text { of area }\end{array}$ \\
\hline & 3-1 & $3-2$ & $3-3$ & $3-4$ & scans \\
\hline C & 81.25 & 83.23 & 83.86 & 89.87 & 84.55 \\
\hline 0 & 13.79 & 12.53 & 11.77 & 8.33 & 11.61 \\
\hline $\mathrm{Na}$ & 1.63 & 1.59 & 1.39 & 0.63 & 1.31 \\
\hline $\mathrm{Al}$ & 1.77 & 1.50 & 1.82 & 0.80 & 1.47 \\
\hline $\mathrm{Si}$ & 0.61 & 0.37 & 0.41 & 0.12 & 0.38 \\
\hline S & 0.24 & 0.19 & 0.20 & 0.06 & 0.17 \\
\hline K & 0.16 & 0.10 & 0.13 & 0.04 & 0.11 \\
\hline $\mathrm{Ca}$ & 0.22 & 0.18 & 0.17 & 0.02 & 0.15 \\
\hline $\mathrm{Ti}$ & 0.10 & 0.05 & 0.05 & 0.01 & 0.05 \\
\hline $\mathrm{V}$ & 0.23 & 0.26 & 0.18 & 0.12 & 0.20 \\
\hline Total & 100.00 & 100.00 & 99.98 & 100.00 & 100.00 \\
\hline
\end{tabular}

[dmr sample psd, eds analysis 9feb15.xIsx]EDS OGF solids 


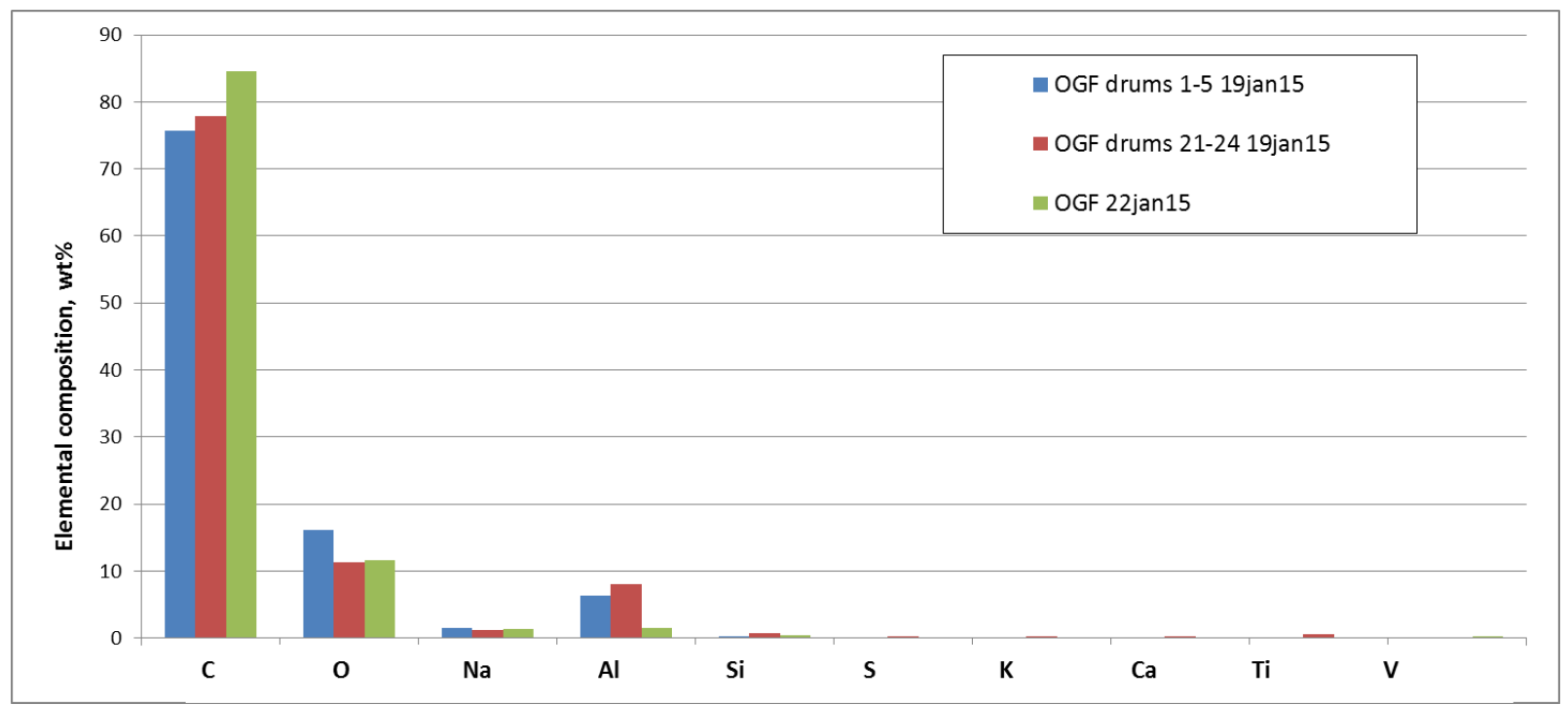

Figure 11-4. Range of elemental concentrations from SEM/EDS analysis for the post-TI-102 OGF solids samples.

Table 11-5. Average of elemental analyses from SEM/EDS for the post-TI-102 OGF solids samples.

\begin{tabular}{|c|r|r|r|r|}
\hline & \multicolumn{4}{|c|}{ Composition, wt\% } \\
\cline { 2 - 6 } & Drum 1-5 & \multicolumn{1}{|c|}{$\begin{array}{c}\text { Drum 21- } \\
\text { Element }\end{array}$} & & $\begin{array}{c}\text { Averages } \\
\text { of area } \\
\text { scans }\end{array}$ \\
\hline $\mathrm{C}$ & 75.63 & 77.85 & 84.55 & $\mathbf{7 9 . 3 4}$ \\
\hline $\mathrm{O}$ & 16.08 & 11.30 & 11.61 & $\mathbf{1 2 . 9 9}$ \\
\hline $\mathrm{Na}$ & 1.57 & 1.13 & 1.31 & $\mathbf{1 . 3 4}$ \\
\hline $\mathrm{Al}$ & 6.30 & 7.99 & 1.47 & $\mathbf{5 . 2 5}$ \\
\hline $\mathrm{Si}$ & 0.20 & 0.65 & 0.38 & $\mathbf{0 . 4 1}$ \\
\hline $\mathrm{S}$ & 0.13 & 0.18 & 0.17 & $\mathbf{0 . 1 6}$ \\
\hline $\mathrm{K}$ & 0.00 & 0.19 & 0.11 & $\mathbf{0 . 1 0}$ \\
\hline $\mathrm{Ca}$ & 0.08 & 0.21 & 0.15 & $\mathbf{0 . 1 4}$ \\
\hline $\mathrm{Ti}$ & 0.00 & 0.50 & 0.05 & $\mathbf{0 . 1 9}$ \\
\hline $\mathrm{V}$ & 0.00 & 0.00 & 0.20 & $\mathbf{0 . 0 7}$ \\
\hline Total & 100.00 & 99.99 & 100.00 & $\mathbf{9 9 . 9 9}$ \\
\hline ;ample psd, eds analysis 9feb15.xIsx]EDS OGF solids \\
\hline
\end{tabular}




\section{OFF-GAS SYSTEM LOW POINT CONDENSATE ANALYSES}

Water condensation has been found in several locations in the off-gas system including the low-point drain valves around the GAC beds. Table 12-1 shows the anion concentrations in the GAC bed inlet and outlet drain condensate samples. The reported anions are present at levels ranging from detection limit values up to around $0.0003 \mathrm{gmol} / \mathrm{L}$, except for $\mathrm{SO} 4$ which ranged up to about 0.005 $\mathrm{gmol} / \mathrm{L}$. If it is assumed that those anions -all represent acids $\mathrm{HF}, \mathrm{HCl}, \mathrm{HNO}_{2}, \mathrm{H}_{2} \mathrm{SO}_{4}, \mathrm{HBr}, \mathrm{HNO}_{3}$, and $\mathrm{H} 3 \mathrm{PO}$, and assuming all those acids are fully dissociated, then the bounding high $[\mathrm{H}]$ concentration and bounding low $\mathrm{pH}$ value can be calculated. The bounding high $[\mathrm{H}]$ concentration in these samples is about $0.011 \mathrm{gmol} / \mathrm{L}$, and a bounding low $\mathrm{pH}$ is about 2 . This $\mathrm{pH}$ value conservatively bounds the test strip $\mathrm{pH}$ values of 2.5-3.9.

Table 12-1. Anion concentrations in low-point drain condensate samples.

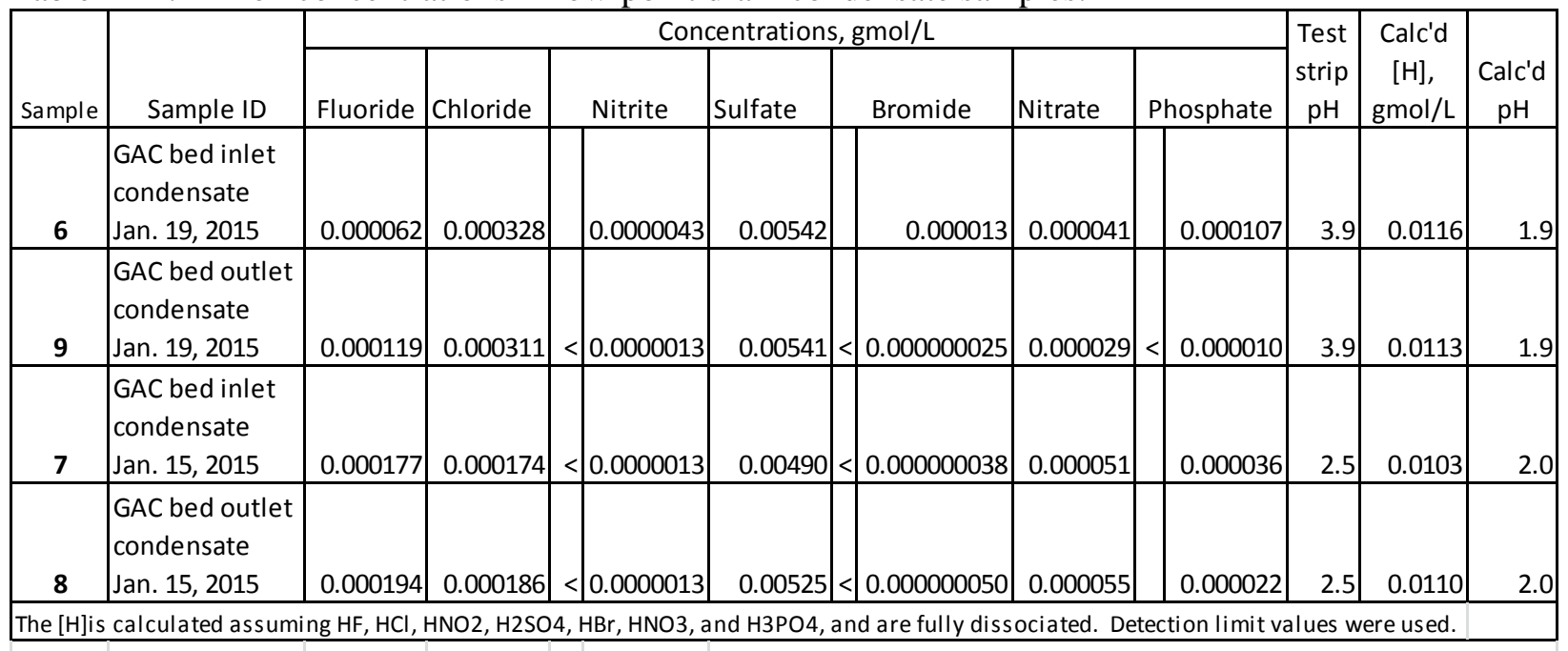

[RDB-006-15 IWTU Ion Chromatography nrs1mar15.xIsx]condensate data 


\section{REFERENCES}

PLN-4871, "IWTU Coal Sampling and Analysis Plan," latest version.

Soelberg, Nick, "DMR, PGF, OGF, and Mersorb/condensate Sample Analyses," BEA external report INL/MIS -15-34361, November 7, 2014. 


\section{APPENDIX A}

\section{IWTU OGF NOV. 202014 SAMPLE ANALYSES}

Nick Soelberg, Rachel Emerson, and Tammy Trowbridge

INTRODUCTION

A sample of solids from the Idaho Waste Treatment Unit (IWTU) Off-gas Filter (OGF) was obtained on November 20, 2014 for analysis to evaluate composition and other properties of this powder material that was filling up the OGF during IWTU operation.

\section{PROXIMATE AND ULTIMATE ANALYSES}

The proximate and ultimate analyses are shown in Table 1.

Table 1. OGF Nov. 20, 2014 sample proximate and ultimate analysis.

\begin{tabular}{|c|c|c|c|c|c|c|c|c|c|c|c|}
\hline & \multicolumn{11}{|c|}{ Weight $\%$ AD (as determined) } \\
\hline Sample Name & $\begin{array}{l}\text { Mois- } \\
\text { ture }\end{array}$ & $\begin{array}{l}\text { Vola- } \\
\text { tile }\end{array}$ & $\begin{array}{l}\text { Bauxite } \\
\text { and ash }\end{array}$ & $\begin{array}{c}\text { Fixed } \\
\text { C }\end{array}$ & $\begin{array}{c}\text { Total } \\
\text { proximate } \\
\text { analysis } \\
\text { (moisture, } \\
\text { Vol, bauxite } \\
\text { + ash, and } \\
\text { Fixed C) }\end{array}$ & $\mathrm{H}$ & C & $\mathrm{N}$ & $\begin{array}{c}\text { O (by } \\
\text { difference) }\end{array}$ & $\mathrm{S}$ & $\begin{array}{c}\text { Total } \\
\text { ultimate } \\
\text { analysis } \\
\text { (moisture, } \\
\text { bauxite + } \\
\text { ash, C, H, N, } \\
\text { O, and S) }\end{array}$ \\
\hline OGF Nov. 202014 sample & 0.36 & 9.28 & 39.34 & 51.02 & 100.00 & 0.17 & 48.40 & 1.16 & 10.30 & 0.27 & 100.00 \\
\hline
\end{tabular}

[OGF Nov 202014 sample analyses 13jan15.xIsx] Prox-ult analysis

The results show that the OGF sample was about $50 \mathrm{wt} \%$ carbon, about $39 \mathrm{wt} \%$ bauxite and ash, and balance $\mathrm{H}, \mathrm{C}, \mathrm{N}, \mathrm{O}$, and $\mathrm{S}$.

\section{SEM/EDS RESULTS}

Samples were analyzed for particle morphology, particle size, and elemental composition using scanning electron microscopy (SEM) and energy dispersive $\mathrm{x}$-ray spectroscopy (EDS). The SEM provides views and photographs of these samples at varying magnifications so we can see individual particles and morphologies. The EDS provides elemental composition of the individual particles viewed in the SEM. However, the accuracy of the EDS for seeing lighter elements like $\mathrm{C}$ is less than for heavier elements like oxygen and higher; and it can't really see $\mathrm{H}$ at all. The ultimate analyses provide better $\mathrm{C}$, $\mathrm{H}$, and $\mathrm{N}$ analyses, for characterizing the presence of coal, charcoal, or coke materials.

Figures 1 and 2 show two different views of the OGF solids magnified 1,000x. While a particle size analysis was not done, these figures show a general bi-modal distribution of particle sizes, with most particles under about 5 micron or over about 10 micron. Most of the mass of the solids appears to be in particles sized between about 30-50 micron.

The figures also show that the particles have mostly sharp angular shapes, which probably contributes to the cohesiveness of the bulk solids mass. 


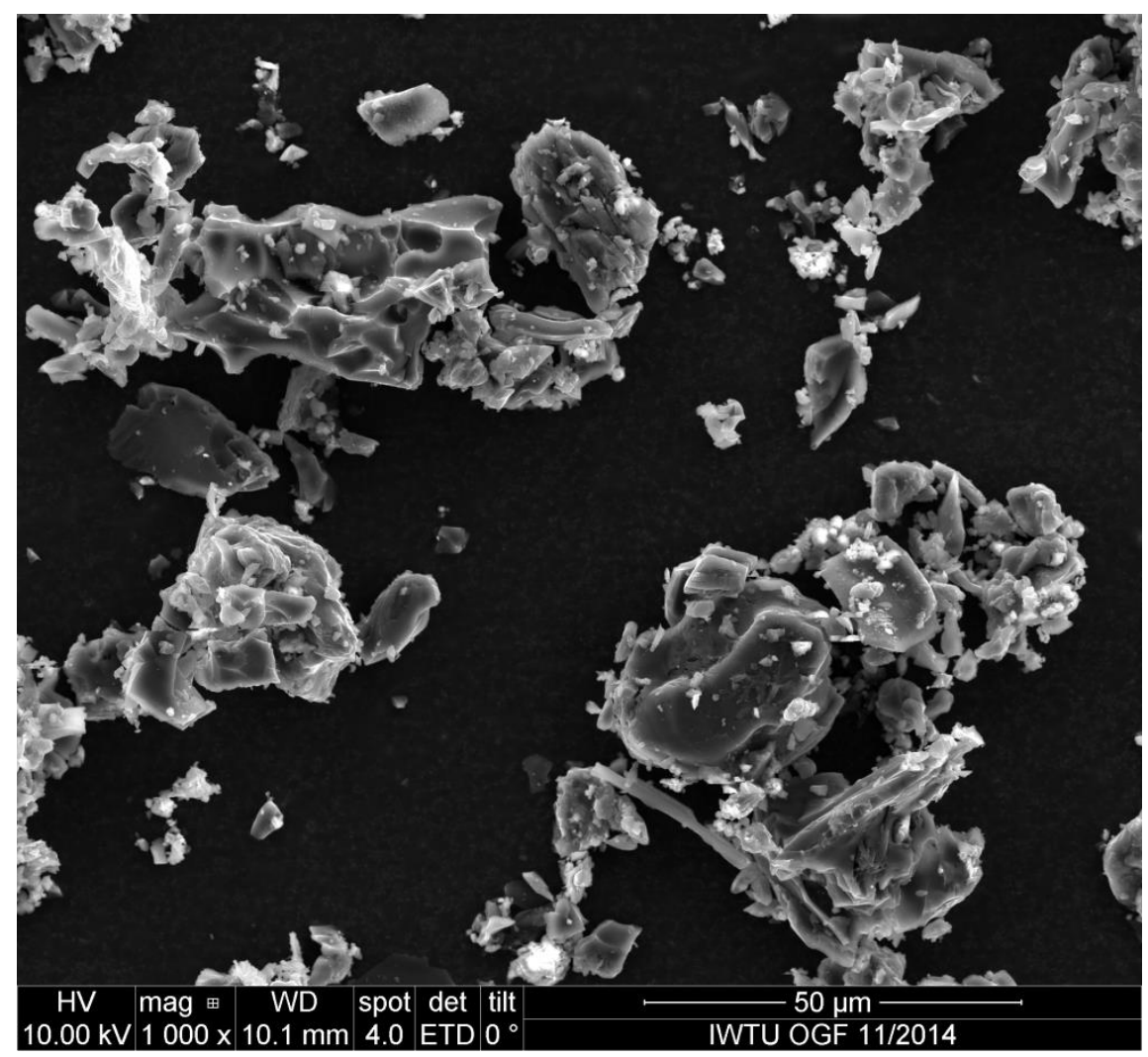

Figure 1. View 1 of the OGF Nov. 20, 2014 solids sample.

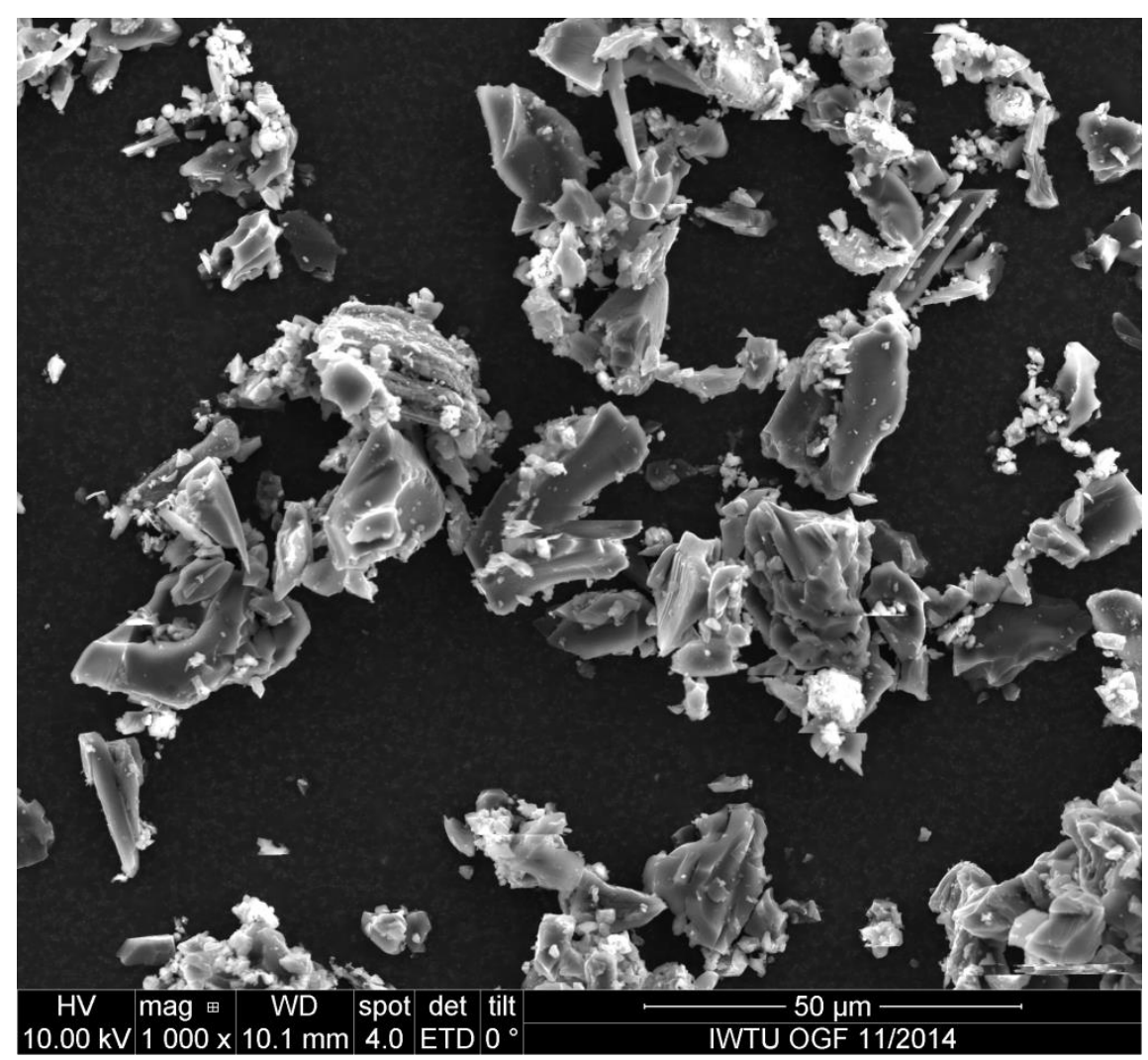

Figure 2. View 1 of the OGF Nov. 20, 2014 solids sample. 
Table 2 summarizes the SEM/EDS results. EDS analyses were done by scanning a field of multiple particles to obtain an average composition and by scanning individual particles to assess the compositions of individual particles. The compositions indicate that some particles are coke particles, indicated by $\mathrm{C}$ levels averaging about $83 \mathrm{wt} \%$. Other particles are more inorganic particles with lower $\mathrm{C}$ content, averaging about $40 \mathrm{wt} \%$, and higher oxides content, averaging about $46 \mathrm{wt} \%$.

Table 2. Elemental analysis from SEM/EDS for the Nov. 20, 2014 OGF sample.

\begin{tabular}{|c|c|c|c|c|c|c|c|c|c|c|c|c|c|}
\hline \multirow[b]{2}{*}{ Element } & \multicolumn{13}{|c|}{ Composition, wt\% } \\
\hline & $\begin{array}{c}\text { EDS } 10 \\
\text { FS }\end{array}$ & $\begin{array}{c}\text { EDS } 11 \\
\text { FS }\end{array}$ & $\begin{array}{c}\text { EDS FS } \\
\text { averages }\end{array}$ & $\begin{array}{c}\text { EDS } 10-1 \\
\text { coke } \\
\text { particle }\end{array}$ & $\begin{array}{c}\text { EDS } 10-2 \\
\text { coke } \\
\text { particle }\end{array}$ & $\begin{array}{c}\text { EDS } 10-3 \\
\text { coke } \\
\text { particle }\end{array}$ & $\begin{array}{c}\text { EDS } 10-4 \\
\text { coke } \\
\text { particle }\end{array}$ & $\begin{array}{c}\text { Coke } \\
\text { particle } \\
\text { averages }\end{array}$ & $\begin{array}{c}\text { EDS 11-1 } \\
\text { bauxite } \\
\text { or ash } \\
\text { particle }\end{array}$ & $\begin{array}{c}\text { EDS 11-2 } \\
\text { bauxite } \\
\text { or ash } \\
\text { particle }\end{array}$ & $\begin{array}{c}\text { EDS 11-3 } \\
\text { bauxite } \\
\text { or ash } \\
\text { particle }\end{array}$ & $\begin{array}{c}\text { EDS } 11-4 \\
\text { bauxite } \\
\text { or ash } \\
\text { particle }\end{array}$ & $\begin{array}{c}\text { Bauxite } \\
\text { or ash } \\
\text { particle } \\
\text { averages }\end{array}$ \\
\hline $\mathrm{C}$ & 69.12 & 71.08 & 70.10 & 93.64 & 89.8 & 80.76 & 82.82 & 82.82 & 32.11 & 46.29 & 42.38 & 37.05 & 40.26 \\
\hline 0 & 21.7 & 21.53 & 21.62 & 5.08 & 2.04 & 11.07 & 12.3 & 12.30 & 67.83 & 40.36 & 54.33 & 30.15 & 54.17 \\
\hline $\mathrm{Al}$ & 1.93 & 1.86 & 1.90 & 0.13 & 2.67 & 0.77 & 1.14 & 1.14 & 0 & 3.08 & 0.54 & 13.91 & 1.21 \\
\hline $\mathrm{Si}$ & 4.14 & 3.49 & 3.82 & 0.18 & 3.86 & 1.56 & 2.43 & 2.43 & 0.03 & 6.27 & 1.51 & 15.25 & 2.60 \\
\hline $\mathrm{Si}$ & 0.39 & 0.39 & 0.39 & 0.3 & 0.4 & 1.23 & 0.14 & 0.14 & 0 & 1.11 & 0.57 & 0.45 & 0.56 \\
\hline K & 0.29 & 0.11 & 0.20 & 0.15 & 0.26 & 1.14 & 0.08 & 0.08 & 0 & 0.15 & 0.13 & 0.28 & 0.09 \\
\hline $\mathrm{Ca}$ & 0.73 & 0.36 & 0.55 & 0.15 & 0.35 & 1.03 & 0.22 & 0.22 & 0 & 0.53 & 0.19 & 0.61 & 0.24 \\
\hline $\mathrm{Ti}$ & 0.32 & 0.15 & 0.24 & 0.1 & 0.27 & 1.03 & 0.18 & 0.18 & 0 & 0.2 & 0.13 & 0.44 & 0.11 \\
\hline $\mathrm{Fe}$ & 1.39 & 1.04 & 1.22 & 0.27 & 0.34 & 1.4 & 0.7 & 0.70 & 0.02 & 2.02 & 0.23 & 1.86 & 0.76 \\
\hline Total & 100.01 & 100.01 & 100.01 & 100.00 & 99.99 & 99.99 & 100.01 & 100.01 & 99.99 & 100.01 & 100.01 & 100.00 & 100.00 \\
\hline
\end{tabular}

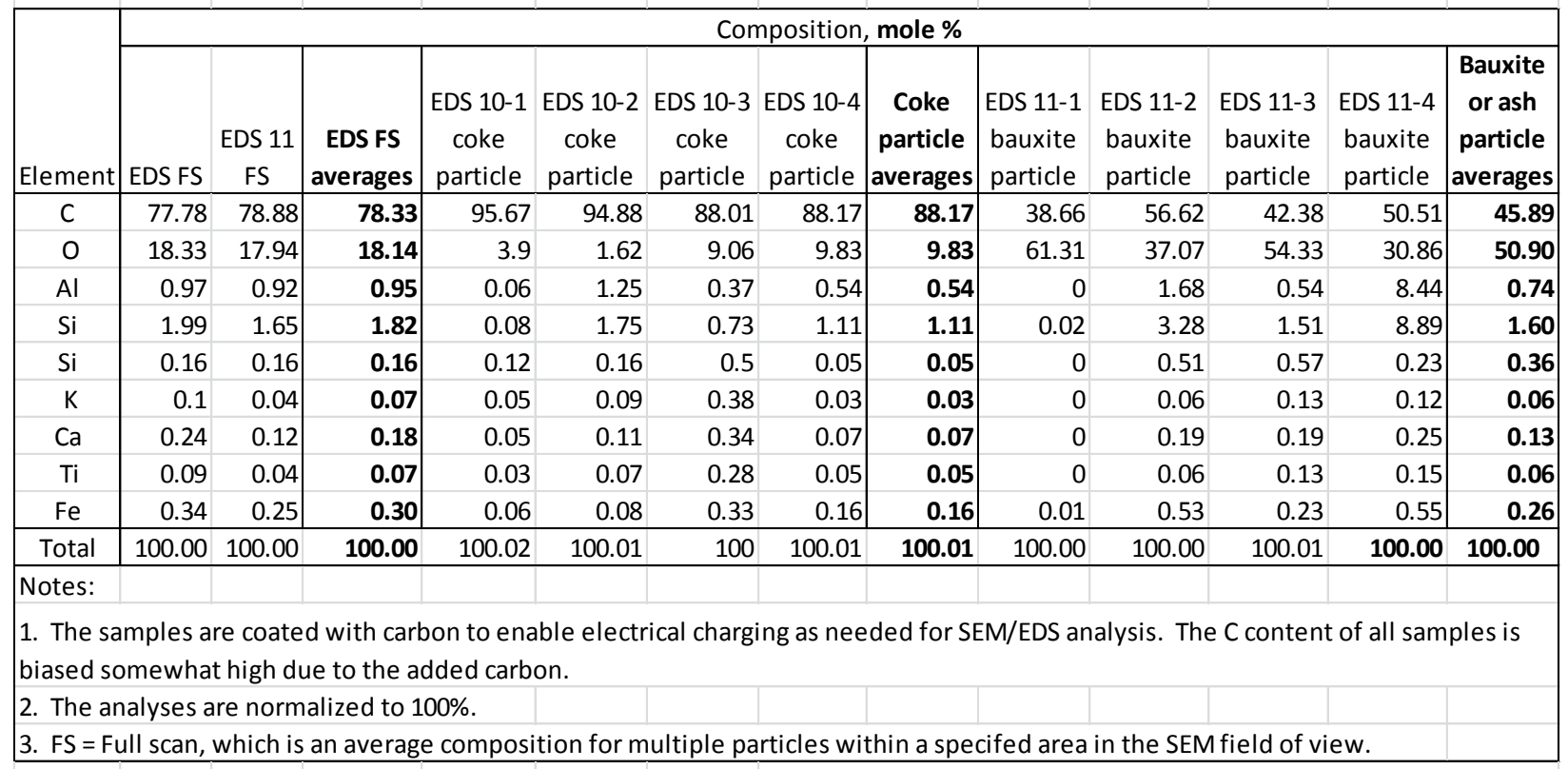

The carbon content in these EDS analyses are biased somewhat high because the samples are coated with $\mathrm{C}$ to provide the electrical conductivity as needed to enable the SEM analysis. These analyses indicate about $70 \mathrm{wt} \% \mathrm{C}$ on average, which is higher than the $\sim 50 \mathrm{wt} \%$ value from the proximate/ultimate analysis. 